*ak RMIS View/Frint Document Cover Sheet tow

This document was retrieved from the Documentation and Records Manaqement (DRM) ISEARCH System. It is intended for Information only and may not be the most recent or updated version. Contact a Document Service Center (see Hanford Info for locations) if you need additional retrieval information.

Accession \#: D196022425

Document \#: SD-WM-SARR-002

Title/Desc:

SAFETY BASIS FOR ACTIVITIES IN DST WITH FLAMMABLE GAS CONCERNS

Pages: 135 


\begin{tabular}{|c|c|c|c|c|c|c|}
\hline \multirow{3}{*}{$\begin{array}{l}\text { 2. ECN Category } \\
\text { (mark one) } \\
\text { Supplemental } \\
\text { Direct Revision } \\
\text { Change ECN } \\
\text { Temporary } \\
\text { Standby } \\
\text { Supersedure } \\
\text { Cancel/Void }\end{array}$} & \multirow{3}{*}{$\begin{array}{r}{[]} \\
{[x]} \\
{[]} \\
{[]} \\
{[]} \\
{[]} \\
{[]}\end{array}$} & \multicolumn{2}{|c|}{$\begin{array}{l}\text { 3. Originator's Name, Organization, MSIN, } \\
\text { and Telephone No. } \\
\text { R. L. Schlosser, SA\&NE, A3-37, } \\
376-7725\end{array}$} & \multicolumn{2}{|c|}{$\begin{array}{l}\text { 3a. USa Required? } \\
\text { [] Yes [X] No }\end{array}$} & $\begin{array}{l}\text { 4. Date } \\
2 / 6 / 96\end{array}$ \\
\hline & & \multicolumn{2}{|c|}{$\begin{array}{l}\text { 5. Project Title/No./Work Order No. } \\
\text { Tank Farms Flammable Gas Safety } \\
\text { Issue }\end{array}$} & \multicolumn{2}{|c|}{$\begin{array}{l}\text { 6. Bldg./Sys./Fac. No. } \\
\text { Tank Farms }\end{array}$} & $\begin{array}{l}\text { 7. Approval Designator } \\
\text { SQ }\end{array}$ \\
\hline & & \multicolumn{2}{|c|}{$\begin{array}{l}\text { 8. Document Numbers Changed by this ECN } \\
\text { (includes sheet no. and rev.) } \\
\text { WHC-SD-WM-SARR-002, REV. } 0\end{array}$} & \multicolumn{2}{|c|}{$\begin{array}{l}\text { 9. Related ECN No(s). } \\
\text { N/A }\end{array}$} & $\begin{array}{l}\text { 10. Related Po No. } \\
\text { N/A }\end{array}$ \\
\hline \multirow{2}{*}{\multicolumn{2}{|c|}{ 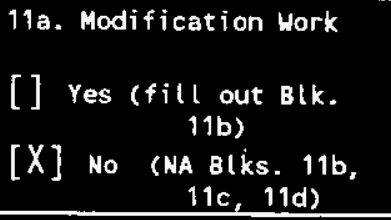 }} & \multirow[t]{2}{*}{$\begin{array}{l}\text { 11b. Work Package } \\
\text { No. } \\
\text { N/A }\end{array}$} & \multirow{2}{*}{\multicolumn{2}{|c|}{$\begin{array}{l}\text { 11c. Modification Work Complete } \\
\text { N/A }\end{array}$}} & \multicolumn{2}{|c|}{$\begin{array}{l}\text { 11d. Restored to Original Condi- } \\
\text { tion (Terp. or Standby ECN only) } \\
\text { N/A }\end{array}$} \\
\hline & & & & & Cog. & er Signature \& Date \\
\hline
\end{tabular}

12. Description of Change

This is full revision to Revision 0 of this report. The purpose of this report is to provide a summary of analyses done to support activities performed for double shell tanks. These activities are encompassed by the flammable gas Unreviewed Safety Question (USQ). A number of safety analyses were conducted for specific activities at tank 241-SY-101. These same activities have been, or will be, done for the other double shell tanks covered by the USQ. The basic controls required to perform these activities involve the identification, elimination and/or control of ignition sources and monitoring for flammable gases. Controls are implemented through the Interim Safety Basis (ISB), IOSRs, and OSDs.

Since this report only provides a historical compendium of issues and activities, it is not to be used as a basis to perform USQ screenings and evaluations. Furthermore, these analyses and others in process will be used as the basis for developing the Flammable Gas Topical Report for the ISB Upgrade.

13a. Justification (mark one)

$\begin{array}{lllllll}\text { Criteria Change } & {[X]} & \text { Design Improvement } & {[]} & \text { Environmental } & \text { [] } & \text { Facility Deactivation } \\ \text { As-Found } & {[]} & \text { Facilitate Const } & {[]} & \text { Const. Error/Onission } & \text { [] } & \text { Design Error/Omission }\end{array}$

13b. Justification Details

See Block 12 for discussion.

14. Distribution (include name, MSIN, and no. of copies)

See attached distribution sheet.
RELEASE STAMP

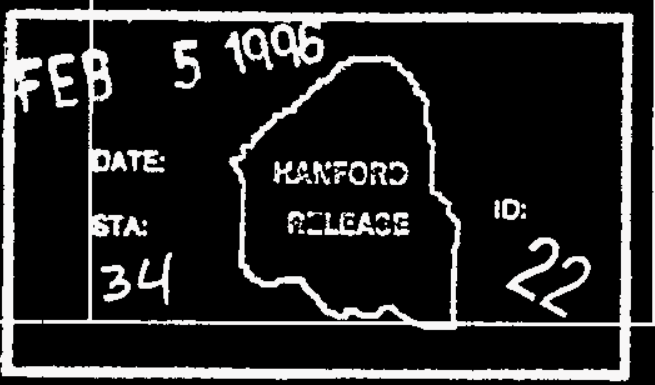




\section{ENGINEERING CHANGE NOTICE}

Page 2 of 2

\begin{tabular}{|c|c|c|c|c|c|}
\hline $\begin{array}{l}\text { 15. Design } \\
\text { Verification } \\
\text { Required }\end{array}$ & 16. Cost In & & & & 17. Schedule \\
\hline $\begin{array}{l}{[] \text { Yes }} \\
{[X] \text { No }}\end{array}$ & $\begin{array}{l}\text { Additional } \\
\text { Savings }\end{array}$ & $\begin{array}{l}\$ \\
\$\end{array}$ & $\begin{array}{l}\text { Additional } \\
\text { Savings }\end{array}$ & $\$$ & $\begin{array}{l}\text { Improvement } \\
\text { Delay }\end{array}$ \\
\hline
\end{tabular}

18. Change Irpact Review: Indicate the related documents (other than the engineering documents identified on side 1 ) SDO/DO

that will be affected by the change described in Block 12. Enter the affected document number in Block 10 .

Functional Dosign Criterio

[] Soismic/stross Analyis
Operating Specification

[]

Criticality Specification

Conereptual Dosion Report

Equipment Spec.

Conte. Spec.

Procurement Spec.

Vondor information

OM Manual

FSARSAR

Safory Equipment List

Radiation Work Permit

Environmental impect Statement

Environmental Report

Environmental Petmit
19. Other Affected Documents:
Streas/Design Raport

[]

[]

[]

[]

[]

[]

[]

[]

[]

[]

[]

[]

[]

[]

Inspection Plan
[]

[]

[]

[]

[]

[]

[]

[]

[]

[]

[]

[]

[]

Esential Material Specification

Fac. Proc. Samp. Schadulo

inventor Adjustrmant Request
Tank Calibration Manual

Health Physics Procedure

Spares Muttipla Unit Listing

Tect Procedurea/Specification

Companent Indax

ASHE Coded hom

Human Fetor Consideration

Computer Sothwar

Eloctric Circuit Schedulo

ICRS Proceduro

Procese Control Manualifien

Process Flow Chart

Purchase Requitition

Tiekler File

indicate that the signin: (NOTE: Docubents listed below will not be revised by this ECM.) signatures below Document Nuber/Revision Docunent Nuber/Revision N/A 
ENGINEERING CHANGE NOTICE

1. ECN (use no. from pg. 1) 193898

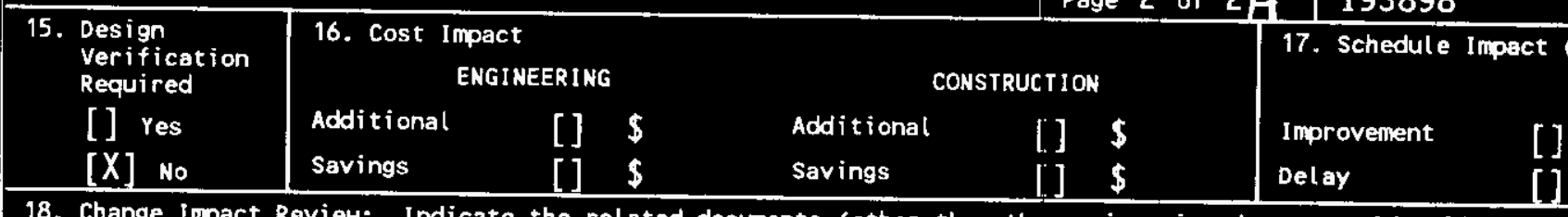

18. Change Impact Review: Indicate the related documents (other than the engineering documents identified on Side 1 ) that will be affected by the change described in Block 12. Enter the affected document number in 81 ock 19. SDD/DD

Functional Design Criteria

[]

[]

Operating Specification

Criticality Specification

Conceptual Design Report

Equipment Spec.

Const. Spec.

Procurement Spec.

Vendor information

OM Manual

FSAR/SAR

Safety Equipment List

Radiation Work Permit

Environmental Impact Statement

Environmental Report

Environmental Permit
[]

[]

[]

[]

[]

[]

[]

[]

[]

[]

[]

[]

[]
Seismic/Stress Analysis
Stress/Design Report

Interface Control Drawing

Calibration Procedure

Installation Procedure

Maintenance Procedure

Engineering Procedure

Operating Instruction

Operating Procedure

Operational Safety Roquirement

IEFD Drawing

Cell Arrangement Drawing

Essential Material Specification

Fac. Proc. Samp. Schedule

Inspection Plan

Inventory Adjustment Request
[]

[]

[]

[]

[]

[]

[]

[]

[]

[]

[]

[]

[]

[]

[]

Tank Calibration Manual

Health Physics Procedure

Spares Muttiple Unit Listing

Test Procedures/Specification

Component index

ASME Coded hem

Human Factor Consideration

Comperter Software

Electric Circuit Schedule

ICRS Procedure

Process Control Manual/Plan

Process Flow Chart

Purchase Requisition

Tickler Filo

19. Other Affected Documents: (NOTE: Documents listed below will not be revised by this ECN.) Signatures below indicate that the signing organization has been notified of other affected documents listed below. Document Number/Revision

Document Number/Revision

Docunent Kumber Revision

$N / A$

20. Approvals

Signature
OPERATIONS AND ENGINEERING

Cog. Eng. R. L. Schlosser forser

Cog. Mgr. E. P/ Oilincenzo

QA J. Weber

Safety M. N. Istan

Environ. N/A

other Safety Basis G. D. Johnson zoldhm

Authorization Basis Manager

J. J. $\mathrm{KLOS}$

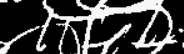

617

Tank Farm Transition Projects J. E. Truax

SEAC J. L. Deichman KMmarus h for JLD

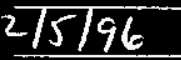

Signature

ARCHI TECT -ENGINEER

PE

QA

Safety

Design

Environ.

other

DEPARTMENT OF ENERGY

Signature or a Control Number that tracks the Approval Signature

ADDITIONAL 


\title{
Safety Basis For Activities in Double-Shell Tanks With Flammable Gas Concerns
}

\author{
R. L. Schlosser \\ Westinghouse Hanford Company, Rich1and, WA 99352 \\ U.S. Department of Energy Contract DE-AC06-87RL10930

\begin{tabular}{|c|c|}
\hline $\begin{array}{l}\text { EDT/ECN: } \\
\text { Org Code: } \\
\text { B\&R Code: }\end{array}$ & $\begin{array}{l}193898 \\
8 M 100 \\
\text { EW3120072 }\end{array}$ \\
\hline
\end{tabular}

Key Words: double-she11 tanks, flammable gas, hydrogen, safety basis, tank farms

Abstract: This is full revision to Revision 0 of this report. The purpose of this report is to provide a summary of analyses done to support activities performed for double shell tanks. These activities are encompassed by the flammable gas Unreviewed Safety Question (USQ). The basic controls required to perform these activities involve the identification, elimination and/or control of ignition sources and monitoring for flammable gases. Controls are implemented through the Interim Safety Basis (ISB), IOSRs, and OSDs.

Since this report only provides a historical compendium of issues and activities, it is not to be used as a basis to perform USQ screenings and evaluations. Furthermore, these analyses and others in process will be used as the basis for developing the Flammable Gas Topical Report for the ISB Upgrade.

TRADEMARK DISCLAIMER. Reference herein to any specific commercial product, process, or service by trade name, trademark, manufacturer, or otherwise, does not necessarily constitute or inply its endorsement, recommendation, or favoring by the United States Government or any agency thereof or its contractors or subcontractors.

Printed in the United States of America. To obtain copies of this document, contact: WHC/BCS Document Control Services, P.O. Box 1970, Mailstop H6-08, Richland WA 99352, Phone (509) 372-2420; Fax (509) 376-4989.
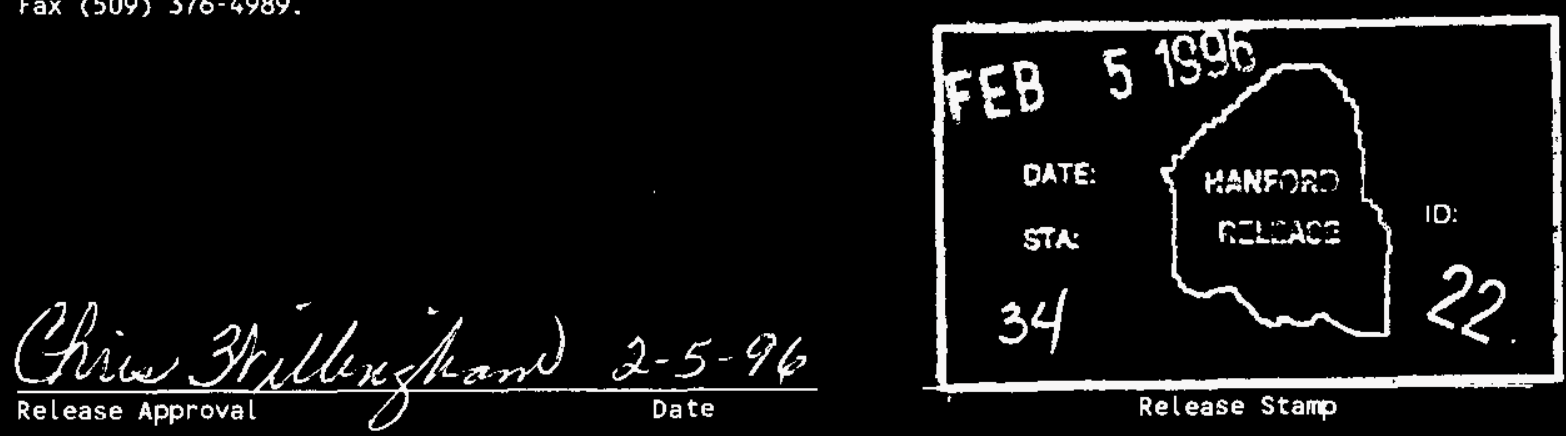

\section{Approved for Public Release}




\section{RECORD OF REVISION}

(2) Title

Safety Basis for Activities in Double-Shell Tanks With Flammable Gas Concerns

(1) Document Number

WHC-SD-WM-SARR002 CHANGE CONTROL RECORO

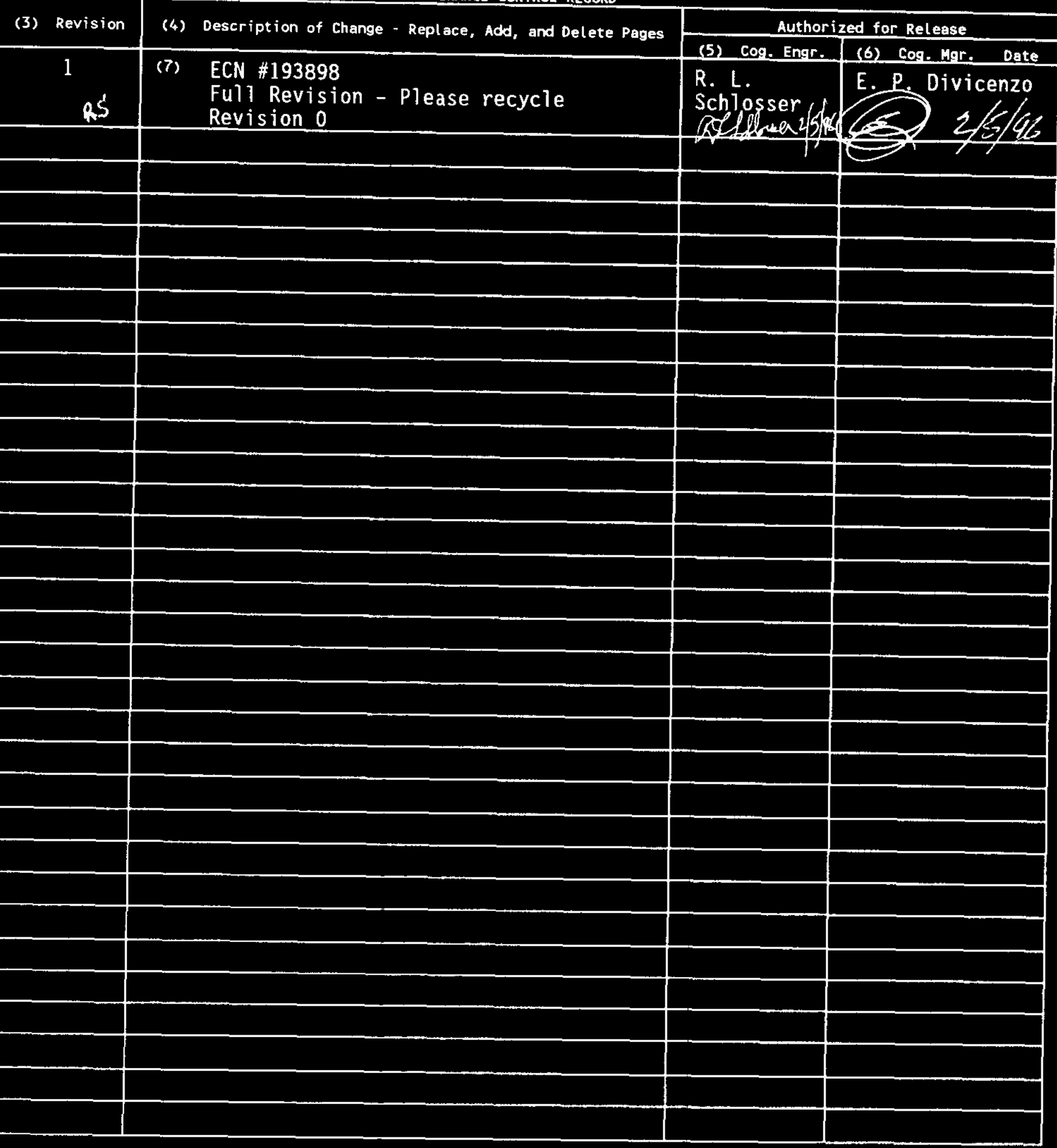




\section{Safety Basis for Activities in Double-Shell Tanks with Flammable Gas Concerns}

Prepared for the U.S. Department of Energy

Assistant Secretary for Environmental Management

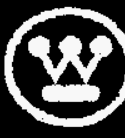

Westinghouse

Hanford Company Fichlard, Washington

Mensgamant and Operations Contrector for the

U.S. Department of Energy under Contract DE-ACD6-87FL 10930

Approved for public release; distribution is unlimited 
WHC-SD-WM-SARR-002 REV 1

This page intentionally left blank. 
CONTENTS

1.0 INTRODUCTION ........................ 1-1

1.1 BACKGROUND ........................ 1-1

1.2 SCOPE . . . . . . . . . . . . . . . . . .

1.3 GAS RETENTION AND RELEASE MECHANISHS .......... 1-4

2.0 DESCRIPTION OF ACTIVITIES ............... 2-1

2.1 MONITORING SYSTEMS $\ldots . . \ldots$ 2-1 $^{2}$

2.1.1 Gas Monitoring System and

Gas Probe Assembly ............ . 2-1

2.1.2 Installation of Gas Monitoring ........... 2-3

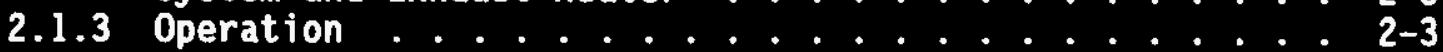

2.1.4 Still and Video Photography ........ 2-4

2.2 EXAMPLE OF A CLOSED-CIRCUIT TELEVISION CAMERA ....... 2-5

2.2 .1 Installation or Removal .......... 2-6

2.2 .2 Operation ................... 2-10

2.3 VAPOR-SPACE SAMPLING ................. 2-10

2.4 GRAB SAMPLING ........................ 2-11

2.5 AUGER SAMPLER ...................... 2-12

2.5.1 Installation or Removal .......... 2-12

2.5.2 Description and Operation .......... 2-15

2.6 PUSH-MODE CORE SAMPLING ............. $2-15$

2.6.1 Installation .............. 2-. 2-.

2.6.2 Operation ........... 2-17

2.7 INSTALLATION MULTIFUNCTION INSTRUMENT TREE ...... $2-21$

2.7.1 Instrument Tree Background ........... 2-21

2.7 .2 Installation ............. 2-... 25

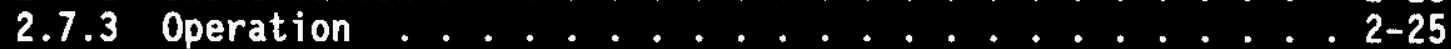

2.8 ROUTINE MAINTENANCE ................ 2-26

2.8.1 Ventilation and Balance Activities
for Actively Ventilated Tanks . . . . . . 2-26

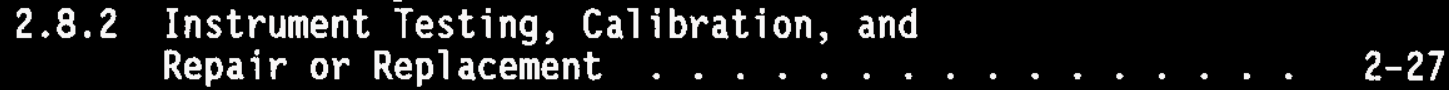

2.8.3 Level-Indicating Device Flushing, ......... 2-27
Repair, or Replacement ......

3.0 IDENTIFICATION OF HAZARDS ............... 3-1

4.0 HAZARD ANALYSIS .................. 4-1

4.1 ELECTROSTATIC SPARKS ............. . . 4-1

4.2 MECHANICAL SPARKS OR FRICTIONAL HEATING ........ 4-1

4.3 EQUIPMENT FAILURE ............... 4-2

4.3.1 Failure of the Standard Hydrogen Monitoring System . . 4-2

4.3.2 Failure of Photographic Equipment ........ 4-3

4.3.3 Failure of the Instrument Tree ......... 4-3

4.3.4 Failure of the Auger Sampler .......... 4-3

4.3.5 Failure of the Push-Mode Core System . . . . . . 4-3

4.4 GAS RELEASE EVENT . . . . . . . . . . . 4-4 
CONTENTS (Cont inued)

4.5 TOXIC GAS RELEASE DURING ACTIVITY . . . . . . . . . . 4-6

4.6 DAMAGE TO TANK ................... . . 4-7

4.7 IMPACT FROM WASTE BERGS ................. . 4-8

4.8 STRATIFICATION . . . . . . . . . . . . . . . . . . . 4-9

4.9 LIGHTNING . . . . . . . . . . . . . . . . . . . . . . . . . 4 4-10

4.10 SPILL OF SAMPLE MATERIAL ................. . 4-11

4.11 SEISMIC .......................... . . . . . . . . . . . . .

5.0 CONSEQUENCE OF ACCIDENTS . . . . . . . . . . . . . . . . . 5-1

5.1 CONSEQUENCES FOR DROP OF SAMPLE MATERIAL . . . . . . . . . . . . $5-1$

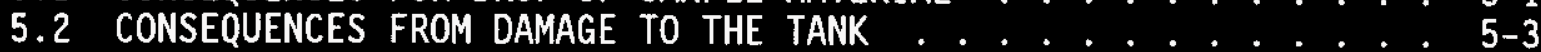

5.3 CONSEQUENCES FROM IGNITION OF A GAS RELEASE . . . . . . . . . . $5-4$

5.4 CONCLUSIONS . . . . . . . . . . . . . . . . . . . 5-6

6.0 CONTROLS ...................... 6-1

6.1 GENERIC CONTROLS ............... 6-1

6.1 .1 Ventilation Controls . . . . . . . . . 6-1

6.1.2 Electrical Grounding and Bonding Controls . . . . . 6-2

6.1.3 Hydrogen Concentration Control . . . . . . . . 6-3

6.1.4 Respiratory and Protection Controls . . . . . . 6-4

6.1 .5 Time of Intrusion . . . . . . . . . . 6-5

6.1 .6 Dome Loading . . . . . . . . . . . . . . . . . . 6-6

6.1 .7 Ignition Source Controls . . . . . . . . 6-6 6- 6

6.2 ACTIVITY-SPECIFIC CONTROLS . . . . . . . . . . . . . . . . 6-7

6.2.1 Standard Hydrogen Monitoring System . . . . . . . 6-7

6.2.2 Still Photography or Closed-Circuit

Television Camera .......... . 6- 6-7

6.2 .3 Grab Sampling . . . . . . . . . . . . . . 6-8

6.2 .4 Auger Sampling . . . . . . . . . . . 6-8

6.2 .5 Push-Mode Sampling . . . . . . . . . . . 6-9

6.2.6 Multifunction Instrument Tree . . . . . . . . 6-9

6.2.7 Routine Maintenance . . . . . . . . . . 6-9

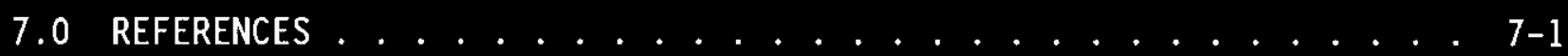

\section{APPENDIXES}

A FREQUENCY OF OCCURRENCE OF IGNITION .............. A-1

B CONSERVATIVE ESTIMATE OF SLURRY GAS COMPOSITION AND LOWER
FLAMMABILITY LIMIT IN THE FLAMMABLE GAS TANKS ....... B-1

C DEVELOPMENT OF THE RISER PURGE TIME REQUIREMENTS . . . . . . . . c c-1

D DEFINITION OF NATIONAL FIRE PROTECTION ASSOCIATION TERMS $\ldots . . . \quad$ D-1

E PEER REVIEW CHECKLISTS . . . . . . . . . . . . . . E-1 


\section{LIST OF FIGURES}

1-1 Nominal Double-Shell Tank Configuration . . . . . . . . . . 1-2

1-2 Axial Temperature Profiles in Tank 241-SY-101 Before Pump Installation . . . . . . . . . . . . . . 1-5

2-1 Double-She11 Tank Cutaway .. . . . . . . . . . . . . 2-2

2-2 Typical Vapor-Space Sampling Probe Assembly . . . . . . . . . 2-7

2-3 Schematic of the Camera and Lights Assembly . . . . . . . . . 2-8

2-4 Guide Tube Assembly . . . . . . . . . . . . . . . . 2-13

2-5 Auger Sampler Assembly . . . . . . . . . . . . . . 2-14

2-6 Schematic of the Auger Bit . . . . . . . . . . . . . 2-16

2-7 Schematic of the Core Drill Truck . . . . . . . . . . . 2-18

2-8 Shielded Receiver and Associated Equipment. . . . . . . . . . 2-19

2-9 Core Sampler Assembly in the Drill String . . . . . . . . . 2-20

2-10 Multifunction Instrument Tree Cross Section . . . . . . . . . . 2-22

2-11 Multifunction Instrument Tree Schematic . . . . . . . . . . 2-23

2-12 Schematic of Connections to the
Multifunction Instrument Tree . . . . . . . . . . . . . 2-24 


\section{LIST OF TABLES}

3-1 Evaluation of Hazards for Double-She11 Tanks with Flammable Gas Concerns ............. . . 3-2

4-1 Comparison of Double-She11 Tank Parameters ... . . . . . 4-5

5-1 Dose Consequences for Spill of Sample Material . . . . . . 5-3

5-2 Ignition Dose Consequences . . . . . . . . . . 5-5

5-3 Radiological Risk Guidelines . . . . . . . . . . . 5-6

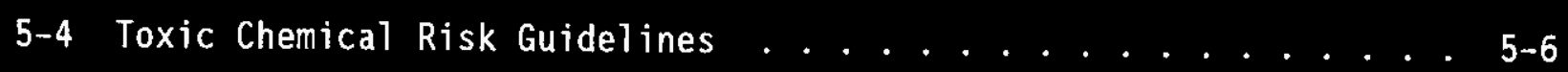




\section{PREFACE}

The purpose of this report is to provide a summary of analyses done to support activities performed for double-shell tanks. These activities are encompassed by the flammable gas Unreviewed Safety Question (USQ). A number of safety analyses were conducted for specific activities at tank 241-SY-101. These same activities have been, or will be, done for the other double-shell tanks covered by the USQ. The basic controls required to perform these activities involve the identification, elimination and/or control of ignition sources, and monitoring for flammable gases. Controls are implemented through the Interim Safety Basis (ISB), IOSRs, and OSDs.

Since this report only provides a historical compendium of issues and activities, it is not to be used as a basis to perform USQ screenings and evaluations. Furthermore, these analyses and others in process will be used as the basis for developing the Flammable Gas Topical Report for the ISB Upgrade. 
WHC-SD-WM-SARR-002 REV 1

This page intentionally left blank. 


\section{SAFETY BASIS FOR ACTIVITIES IN DOUBLE-SHELL TANKS WITH FLAMMABLE GAS CONCERHS}

\subsection{INTRODUCTION}

\subsection{BACKEROUND}

Past reactor fuel reprocessing operations conducted at the U.S. Department of Energy's Hanford Site have generated radioactive 1 iquid and solid wastes. The wastes are stored in underground storage tanks that were built in clusters and designated "tank farms." There are 18 tank farms; each farm contains from 2 to 18 tanks of similar design. All of the tank farms are located in the 200 East and 200 West Areas of the Hanford Site.

Between 1968 and 1986, 28 double-she11 tanks were built. Twenty-five of the double-shell tanks are grouped into five tank farms in the 200 East Area (241-AN, 241-AP, 241-AW, 241-AY, and 241-AZ). The remaining three doubleshe 11 tanks are grouped into one tank farm in the 200 West Area (241-SY).

Each tank consists of three concentric structures as shown in Figure 1-1. The outmost structure is a reinforced concrete tank designed to sustain soil loadings, dead loads, live loads, and temperature gradients generated by the radioactive wastes contained within the tank (Koontz 1986).

The reinforced concrete tank is 1 ined with a carbon steel 1 iner referred to as the secondary tank. The inner, free-standing, completely enclosed carbon-steel tank is referred to as the primary tank. An annular space separates the steel tanks. The primary tank is designed to contain the radioactive waste materials. The secondary steel tank would contain any 1 iquid leakage from the primary tank until the tank contents can be transferred to available storage space (Koontz 1986). This design meets the intent of double-containment for hazardous material storage under the Resource Conservation and Recovery Act of 1976 (42 USC 6901).

The free-standing primary tank is $22.86 \mathrm{~m}(75 \mathrm{ft})^{*}$ in diameter and $14 \mathrm{~m}$ (46 ft) high at the dome crown. The tanks were designed for holding a 1 iquid volume of 4,392,000 L $(1,160,000 \mathrm{gal})$ except for the 241-AY and 241-AZ tanks which hold a total of $3,785,400 \mathrm{~L}(1,000,000 \mathrm{ga} 1)$. The operating levels (corresponding to waste volumes) are lower than these values.

Both the primary tank and the annulus are actively ventilated (by separate ventilation systems). The annulus ventilation system routes air from the center bottom of the secondary tank through slots in the insulating concrete to the annulus. The primary ventilation draws air from the tank

"The tanks were built using English units. Most conversions in this document take the English measurement and convert it to the exact metric value. 


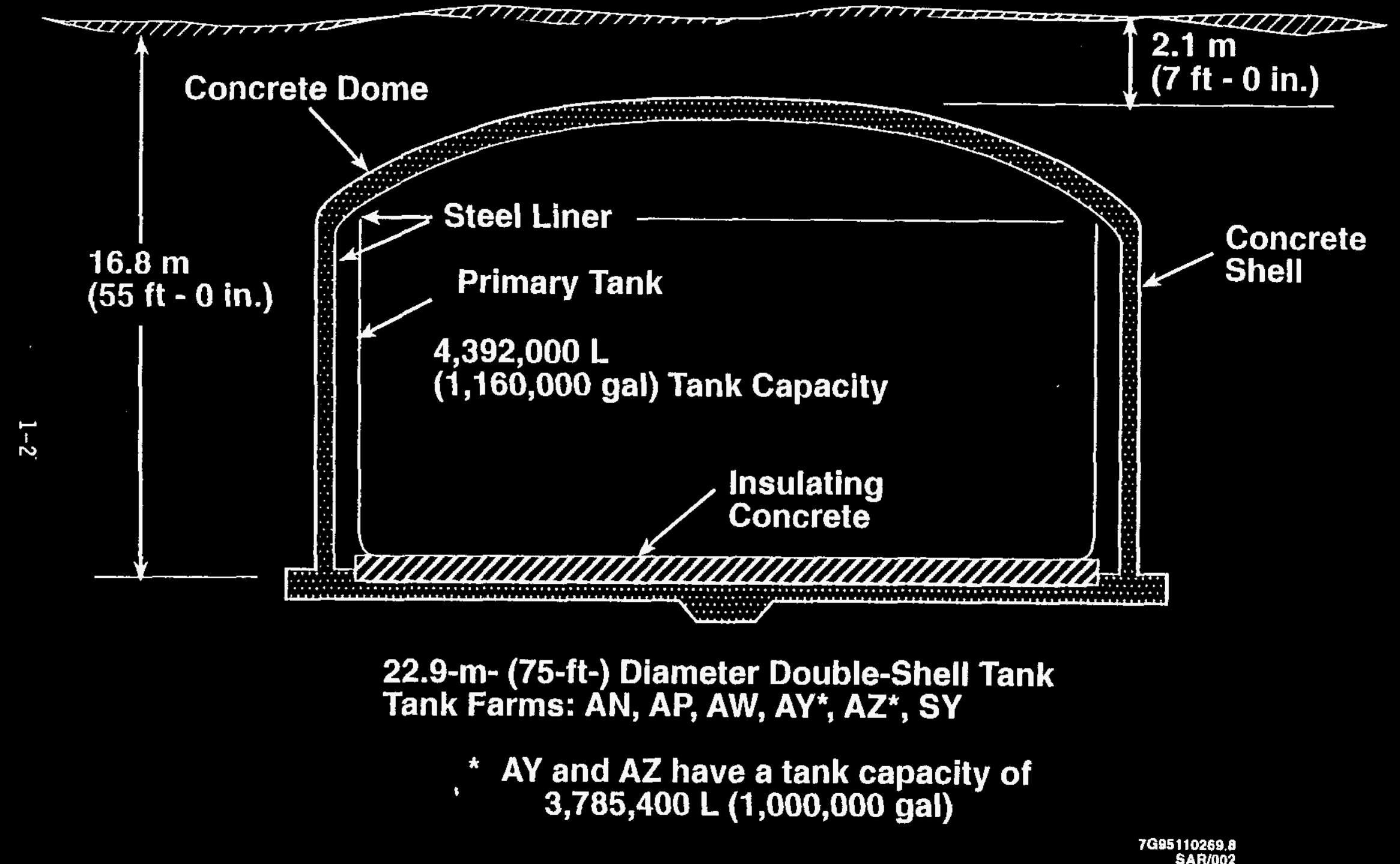

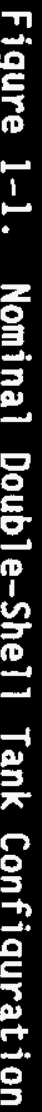


through a riser into the exhaust lines. In-leakage through the pump-pit drain and risers provides the make-up air. The 241-SY farm, in contrast, has filtered inlets on the primary tank.

In the first part of 1990 , a flammable gas unreviewed safety question was declared to exist (Daugherty 1990, Lawrence 1990). The original statement of the unreviewed safety question was a potential release of flammable gas with its own oxidizer. This mixture would be flammable even if the tank were inerted with another gas, such as nitrogen. The original unreviewed safety question involved 22 of the 23 original tanks on the flammable gas watch 1 ist. Tank 241-SX-109 was the exception because, although it does not retain or release flammable gases, six flammable gas watch list tanks vent through it.

As of November 1, 1995, the flammable gas unreviewed safety question affects 25 tanks; tanks 241-AW-101 and 241-U-107 were added since the original 1 ist was compiled. Six of the twenty-five tanks are double shell:

241-AN-103, 241-AN-104, 241-AN-105, 241-AW-101, 241-SY-101 and 241-SY-103. These tanks all exhibit episodic releases", i.e., a period of growth where the surface levels rise because gases are retained, then a relatively quick release (several minutes to several days). Nineteen single-shell tanks round out the flammable gas watch 1 ist. They are tanks 241-A-101, 241-AX-101, 241-AX-103, 241-S-102, 241-S-111, 241-S-112, 241-SX-101, 241-SX-102, $241-S X-103,241-S X-104,241-S X-105,241-S X-106,241-S X-109,241-T-110$, 241-U-103, 241-U-105, 241-U-107, 241-U-108, and 241-U-109. Tank 241-SX-109 is on this 1 ist only because the other six flammable gas tanks in the $S X$ tank farm vent through it. Generally, these single-shell tanks do not exhibit episodic rollover release behavior similar to tank 241-SY-101 (see also Section 4.4). They were placed under the flammable gas unreviewed safety question because their waste types are similar to those in the tanks that exhibit episodic behavior and/or unexplained growth of the waste-level height over time.

\subsection{SCOPE}

The purpose of this document is to study performing selected activities in double-shell tanks with flammable gas concerns. These activities are the same or very similar to activities that already have been performed in or on tank 241-SY-101. The basic tenets for the safe conduct of these activities will be the same as those used for tank 241-SY-101, i.e., to control ignition sources and to limit the activities to a period of time when the concentration of flammable gases is not expected to reach concentrations of concern.

Van Vleet (1994) discusses the single-shell tanks with flammable gas concerns

\footnotetext{
* Episodic releases' are commonly included in the term 'gas release events' in this document. The term 'gas release event' may be more general because it includes natural and activity-based releases. The term 'rollover event' is a gas release event involving the exchange of fluids (bottom to top) in a tank.

** If flammable gases are produced, retained, and released, they may cause the entire vapor space or a portion of the vapor space of a tank to reach the lower flammability limit.
} 
and Graves (1994) discusses the steady-state flammable gas generation in all tanks. Other tanks may fall under the flammable gas unreviewed safety question as characterization and evaluation continue. NOTE: This document is not procedurally part of the authorization basis until a change is made to the Hanford Site Tank Farm Facilities Interim Safety Basis (Leach and Stahl 1995).

The following sections describe the activities to be conducted in the double-shell tanks with flammable gas concerns. Hazards are identified and analyzed, consequences are calculated, and controls are developed. The intention is to perform these activities in a safe and environmentally sound manner. The U.S. Department of Energy has issued the Environmental Assessment (EA) and Finding of No Significant Impact (FONSI) for the Waste Tank Safety Program at the Hanford Site (DOE/EA-0915) (DOE 1994).

\subsection{GAS RETENTION AND RELEASE MECHANISMS}

Tank 241-SY-101 contains $3,785,800 \mathrm{~L}$ (1 million gal) of waste that was concentrated at the 242-S Evaporator and placed in the tank between 1977 and 1980. Initially, 1,073,200 L (274,000 gal) of double-shell slurry (the most concentrated material produced by the evaporators and containing high concentrations of hydroxide, nitrate, and aluminate) was pumped into the tank. Subsequent additions of waste to the tank included complexed concentrate waste (an evaporator product similar to double-shell slurry but not as concentrated and containing significant organic complexant concentrations) and double-she11 slurry waste through 1980 (Babad 1991a). Shortly after the waste was pumped into the tank, the waste began to expand from the generation of gases, which include hydrogen, nitrous oxide, nitrogen, and ammonia. In 1990, this tank, along with others, was declared to have an unreviewed safety question. Efforts to characterize the tank contents have included gas sampling and analyses, temperature monitoring, displacement monitoring, core sampling and remote video observations.

Between rollovers, the waste used to settle into two distinct layers. The convective layer (see Figure 1-2) is assumed to be mobile and remains mixed as a result of convective motion. Consequently, gases generated in this layer are assumed to be released steadily. The bottom nonconvective layer (see Figure 1-2) does not move and is assumed to retain all of the gas that is generated in this region until a rollover. The convective- and nonconvectivelayer terminology is inferred from the observed axial temperature profiles in the tank between rollovers. A flat temperature profile in the convective layer indicates convective mixing, whereas an almost parabolic temperature profile in the nonconvective layer represents conductive heat transport.

Several mechanisms have been proposed to explain the generation, retention, and release of gas (Babad 1991b). Although considerable uncertainty exists with these mechanisms, the existing data suggest that a "rollover" of the nonconvective layer occurs periodically, which releases the gas.

The chemical reactions occurring in the tank that result in gas generation have not been fully characterized. However, it is known that the reactions involve the organics and are assisted by the radiation. In the 
WHC-SD-WM-SARR-002 REV 1

Figure 1-2. Axial Temperature Profiles in Tank 241-SY-101 Before Pump Installation.

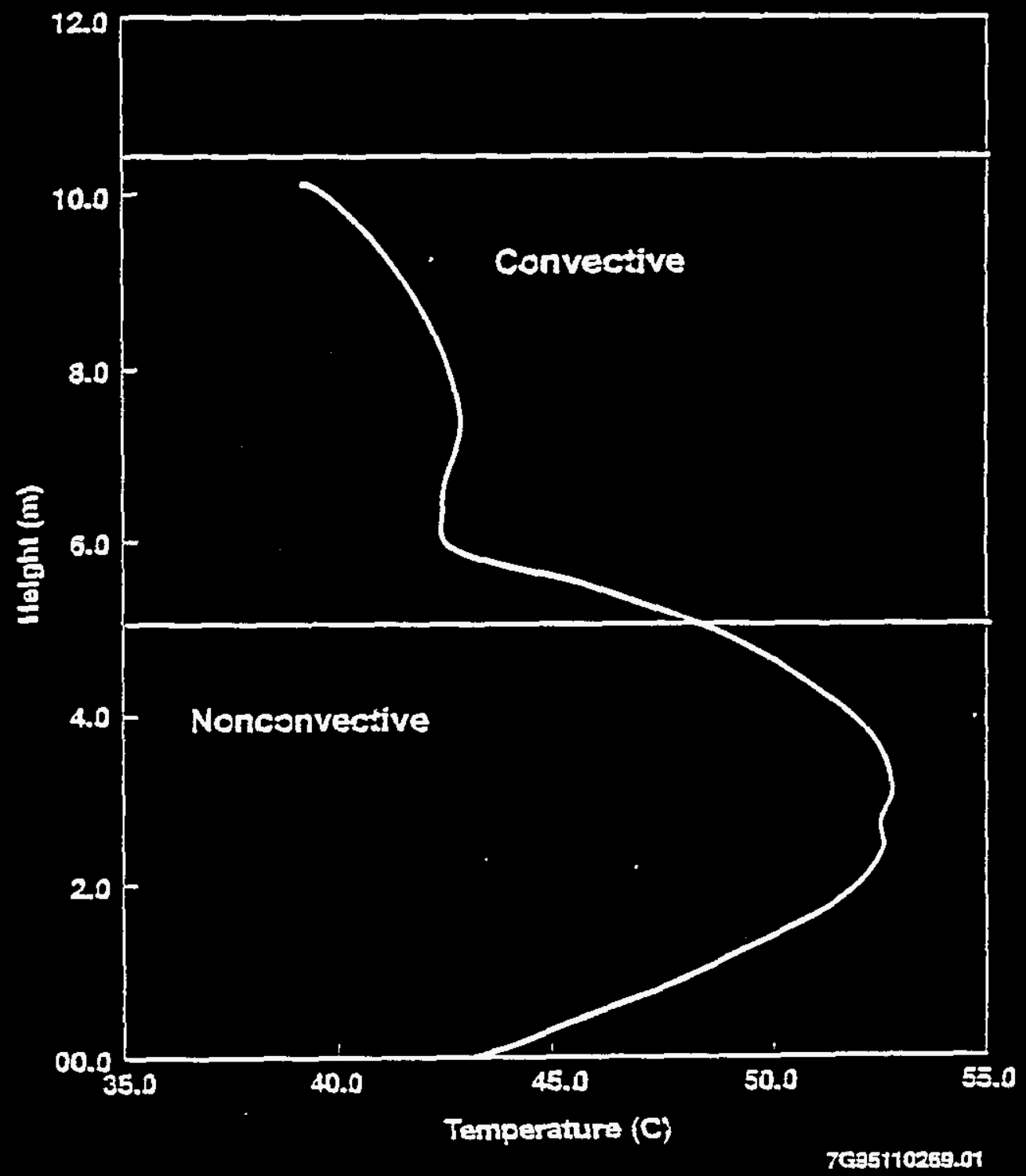


convective layer, the motion of the fluid brings the gas generated in that layer up to the surface, where it can be released. As a result, the gas does not accumulate in the fluid layer. However, in the nonconvective layer, the waste does not move, and most of the gas formed in this layer is retained. As gas accumulates, the nonconvective layer becomes less dense. The temperature rises, with several possible consequences: the accumulated gas expands, further decreasing the density; the viscosity of the material decreases; some of the solid material redissolves in the warmer temperature; and the chemical reactions rate may increase. As a result of some or all of the above occurrences, the nonconvective layer reaches a critical density and becomes buoyant. This causes instability, and the lower region rolls over to the top (i.e., this is termed a Rayleigh-Taylor instability). When this happens, the hydrostatic head decreases, the pressure on the accumulated gas drops, and the bubbles expand, which further increase the buoyancy. The gas releases when it reaches the surface.

Eventually, enough of the accumulated gas is released so that the density increases and the solids settle out. The nonconvective layer forms again on the bottom, and the cycle begins again.

Other double-shell tanks also appear to have episodic behavior, albeit to a lesser extent than tank 241-SY-101. These other tanks appear to have a convective and nonconvective layer. The depths of these layers were inferred from the observed axial temperature profiles. Newer data, such as core samples, in situ void fraction measurements, and in situ viscometer data, also show the existence of the convective and nonconvective layers. 


\subsection{DESCRIPTION OF ACTIVITIES}

This section addresses selected activities in and around double-shell tanks with flammable gas concerns, as defined in Section 1 . Activities associated with monitoring systems; still and video photography; vapor-space; grab, auger, and push-mode waste sampling techniques; multifunction instrument trees; and routine maintenance are discussed in the following sections.

\subsection{HONITORING SYSTEMS}

A11 177 tanks, single- or double-she11, may be equipped with thermocouple trees (temperature-measuring devices in waste and dome space); leve1-indicating devices, an observation port through which a camera can be inserted to take photographs of the inside of the tank; and a dome elevation bench mark (dome-deflection monitoring device). Some tanks have leak detection laterals (horizontal dry wells underneath the tank). Figure 2-1 illustrates typical types of monitoring devices that are used on double-shell tanks.

\subsubsection{Gas Monitoring System and Gas Probe Assembly}

The standard hydrogen monitoring system is used to measure the hydrogen concentration in the tanks with greatest concern. The standard hydrogen monitoring system was developed to sample Class 1 , Division 1, Group B (hydrogen) atmosphere. A1l of its components meet the National Fire Protection Association's National Electrical Code (NFPA 1994) requirements for operating in a hydrogen environment.

The standard hydrogen monitoring system provides online continuous measurements of gas samples for hydrogen content and to allow for more detailed laboratory analyses of grab samples. Details are provided in the design documentation (Atencio 1992). The hydrogen sensors used are electrochemical cells that provide an electrical signal proportional to the hydrogen partial pressure in the gas sample. The low-range sensor is calibrated for a hydrogen concentration range of 0 to 1 percent, while the high-range sensor is calibrated for 0 to 10 percent hydrogen".

One of the main components of the sampling system, the auxiliary flow loop provides a redundant hydrogen monitoring system. This system is a duplicate of the main flow loop. A flow indicator and controller is provided to measure and control low-volume flows.

*NOTE: Appendix B develops a lower flammability limit for the flammable gas tanks. It accounts for hydrogen, ammonia, methane, and carbon monoxide in addition to the oxidizers of oxygen and nitrous oxide. Using this approach and setting monitoring requirements for hydrogen only (this is all the electrochemical cell detects) gives 2.5 percent hydrogen as the lower flammability limit and 0.625 percent $(6,250 \mathrm{ppm})$ as $1 / 4$ the lower flammability limit. 
WHC-SD-WM-SARR-002 REV 1

Figure 2-1. Double-She11 Tank Cutaway.

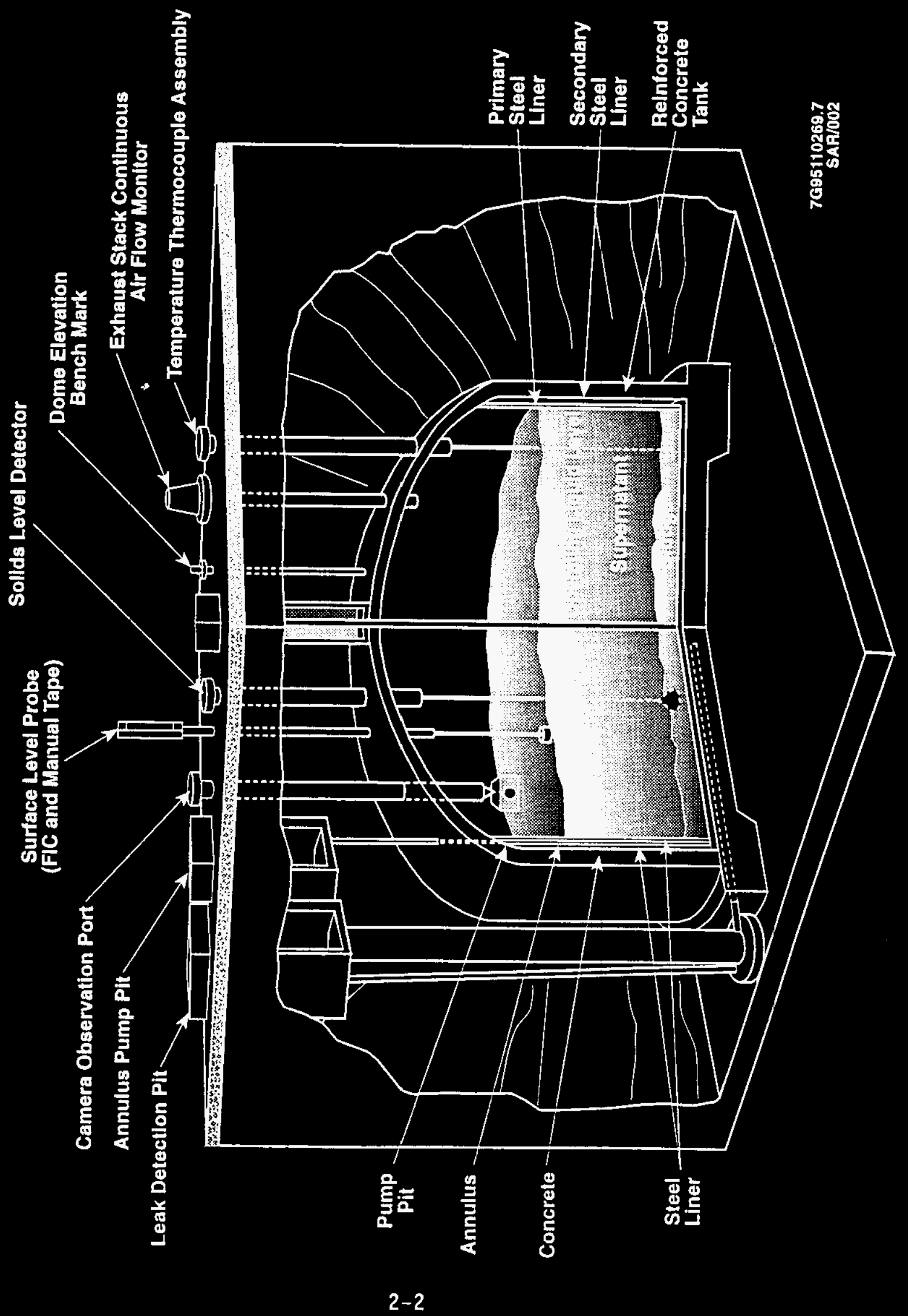


An alarm and annunciator system is provided on the monitoring system. The electrochemical sensors are set to alarm for high hydrogen concentrations. The alarm provides audible and visual indications that the system needs to be maintained, or that the hydrogen level in the tank is above a preset percentage of the lower flammability limit.

\subsubsection{Installation Of Gas Honitoring System And Exhaust Header}

The standard hydrogen monitoring system may be installed in four different configurations as follow: on the exhaust header, on a gas probe assembly, on a multifunction instrument tree assembly, or on a modified riser flange. For double-shel1 tanks, the standard hydrogen monitoring system is installed on exhaust headers.

Installation on the exhaust header of a tank requires that two holes be drilled in the horizontal leg of the exhaust system. Hot metal particle from the drilling operation cannot fall into the tank because the drilling is in the horizontal leg of the system and the ventilation flow is pulling the particles away from the vertical leg. Drilling holes into the exhaust header and its relation to the horizontal and vertical legs is addressed in Marusich et al. (1991). The possibility of the drill igniting a postulated flammable concentration of hydrogen was found to be incredible. Small heated metal bars or spheres have to reach a temperature of $800{ }^{\circ} \mathrm{C}$ to cause auto ignition of hydrogen in air. Drilling into the metal exhaust header may cause frictional heating and small particles on heated metal. Laboratory tests have shown that the maximum temperature reached while drilling at high revolutions per minute with high force being placed on the drill bit and without using the nonvolatile fluid to aid in cutting and cooling the drill bit was $260{ }^{\circ} \mathrm{C}$. A nonvolatile fluid (water) is used as an aid to cutting and to cool the drill bit and the surrounding metal. Once the hole is drilled, a saddle clamp with a prethreaded port is installed over the hole. A valve fitting would then be installed and the standard hydrogen monitoring system would be attached by tubing to this fitting.

Installation on the exhaust header is a simple operation of connecting tubing from the assembly to the environmentally controlled system enclosure, and connecting return tubing from the enclosure to the return line on the exhaust header. After the tubing is connected to the fitting, a protective cover is placed over the fitting to prevent damage. Valving that is already installed on the exhaust header is used to isolate the standard hydrogen monitoring system from the tank environment until after the standard startup procedure has occurred. After the system has been leak tested and calibrated, the valving may be opened to allow sampling of the tank vapor space.

\subsubsection{Operation}

The operation of the standard hydrogen monitoring system permits the continuous sampling and monitoring of the tank gases for hydrogen.

A standard system startup is performed. This startup is described in detail in Atencio (1992). It includes verification of alarms, a leak test, and calibration of the instruments. The standard hydrogen monitoring system 
is then be placed in service. The information from the instruments is recorded locally, and the system has the capability of being connected to an automated data acquisition system.

Routine maintenance is required to support continuous monitoring. These activities include calibration of the sensors, readout and recorder, pressure indicators, and strip chart recorder; and replacement of filters and strip chart paper.

\subsubsection{Sti11 and Video Photography}

In-tank still and video photography in double-shell tanks that have a flammable gas concern may be needed for one or more of the following purposes:

Inspect the tank interior to ascertain the condition of the tank. Monitor the condition of the waste in the tank. Evaluate the condition of other instrumentation.

Assist in installation and/or removal of other instrumentation.

Approved still-photography equipment for operation in double-shell tanks with flamable gas concerns currently is not available.

Safety assessments for video in-tank photography in double-shell tank 241-SY-101, a tank with flammable gas concerns, have been performed in safety documents WHC-SD-WM-SAD-005 (Van Vieet [1991], and LA-UR-92-3196 [LANL 1995]).

For photography to be allowed in double-shell tanks with flammable gas concerns, the equipment used must conform to the following criteria, as specified in Section 30.2.A.4 of OSD-T-151-00030 (or latest revision) (WHC 1996):

Lighting to be Underwriter's Laboratory 1 isted for use in Class 1 , Division 1, Group B; a flammable hydrogen atmosphere.

All other electrical components located inside the tank that are not Class 1, Division 1, Group B will be purged and pressurized with instrument air or inert gas in accordance with the National Fire Protection Association, Inc., Article 496, Type $X$ purging, to conform with the requirements of the National Electrical Code, Article 501 for use in the flammable hydrogen atmospheres.

Purge-gas system to have redundant safety instruments to alarm and automatically shut off electrical power to the electrical components served by the purge-gas system due to loss of gas pressure. If required by the safety classification of the equipment of the NFPA classification for the location where the equipment is installed, whichever is more stringent.

In tank 24-SY-101, radiation shielding of the replacement plug to be equal to original 42 -in. shield plug.

In-tank inspection using a still photo camera requires approval by WTO and WTPE. 
In-tank photographic hardware exposed to the tank vapor space is made of materials (e.g., stainless steel, semiconductive plastic) that are resistent to mechanical and electrostatic sparks, per requirements in Section 30.2.A of OSD-T-151-00030 (WHC 1996).

Video power and signal wires in the tank are sheathed in spark resistent materials, as above, and the sheath tube (metal or plastic) purged.

The support cable or shaft has a depth-limiting device to prevent the video or light system from contacting the waste.

A temporary riser cover or glove bag is provide to maintain confinement of vapor space gases during operations.

Contamination control for the camera and/or light system is implemented by lining the riser with cleanable or disposable metal and/or plastic sleeves.

\subsection{EXAMPLE OF A CLOSED-CIRCUIT TELEVISION CANERA}

The tank 241-SY-101 camera and lights assembly was developed to operate in a Class I, Division 1, Group B (hydrogen) atmosphere. The camera (Type $X$ purged system) and lights assembly ( 1 isted for Class $I$, Division 1 , Group $B$ ) meets the requirements for operating in a hydrogen environment as described in the National Fire Protection Association's National Electric Code* (NFPA 1993). Electrical components, such as the control system, are located outside the tank in a nonclassified area and are not in contact with the tank atmosphere. The same system is installed in tank 241-SY-103.

The supply system for the inert purge gas has been modified for the camera systems in tanks 241-SY-101 and 241-SY-103. The tank 241-SY-101 system did use purge gas supplied by bottles located on the tank. The camera system used approximately one bottle of inert gas per day. The new supply system supplies inert gas from a dewar located outside of the SY Tank Farm boundary.

A second camera system has been developed for use in tank 241-SY-101 and the other double-shell tanks with flammable gas concerns. It is similar to the other system except that the lights are arranged in a different pattern. This allows the assembly to fit inside a $50.8-\mathrm{cm}(20-i n$.$) riser versus the$ $106.7-\mathrm{cm}(42-i n$.$) riser required for the old system. Because no 50.8-\mathrm{cm}$ $(20$-in.) risers exist on the AN or SW tanks, a multiport riser adapter is used. This adapter fits on a $106.7-\mathrm{cm}(42-\mathrm{in.})$ riser and provides three smaller riser openings in place of one large opening. The inert gas for this system also is supplied by a dewar located outside the tank farm boundary. Additionally, an assembly to fit inside a $30.5-\mathrm{cm}(12-\mathrm{in}$.) riser has been designed. These assemblies have been placed in the double-shell tanks with flammable gas concerns in the AN and AW Tank Farms.

A central stem will support the camera and lights or the 1 ights only. Electrical cables and purge gas lines are enclosed inside the stem and customdesigned connection boxes, except at the stem base where the purge-gas tube

\footnotetext{
*See Appendix D for the National Fire Protection Association definitions.
} 
and camera cable run externally to the camera. Lighting fixtures will be rigidly mounted on the central stem. The camera and the pan and tilt unit will be supported under the lights. The original shielding plug drawing was used as a basis for design of the replacement shielding plug. A support stand for the shield plug during initial assembly, testing, repair, and removal of the camera and lights/lights assemblies is shown in Figure 2-2. Lifting bails and points will be provided for ease of assembly of, installation into, and removal from the tank.

The central stem will be sealed to the riser flange by means of a gasket, which can be tightened after the camera is adjusted to the desired height. Purge gas will be routed back through the riser flange to exhaust it into the tank. Thorough operational testing of each assembly will be completed before and after transport to the tank farm for installation.

\subsubsection{Installation or Removal}

Installation of the oldest design of closed-circuit television camera and 1 ights assemblies involves opening large-diameter tank risers. A fixture, the shield plug removal/installation confinement seal fixture, has been constructed to maintain confinement without loss of negative pressure in the tank to unacceptable levels $(-62.3-\mathrm{Pa}$ or $-0.25-\mathrm{in}$. water column) and to provide positive contamination control. The new radiation shielding plugs have a cylinder for which the closed-circuit television camera(s) with lights or lights only can be totally withdrawn (see Figure 2-3). This cylinder, along with the new shielding plug, provides a flat-bottomed cylinder with a circular sealing surface and controlled geometry annular gap. The ventilation system will maintain an acceptable negative pressure with an opening of up to $50.8 \mathrm{~cm}$ (20 in.) in diameter.

The camera system/riser plug support stand is positioned near a riser so that a crane can move the system from the stand to the riser. The new shielding plug assembly is lifted into position on the support stand. The electrical cables and purge-gas lines are attached to top connections on the support stem. The support stem is lifted and guided through the shielding plug until the lower end rests on the upper end of the camera and lighting subassembly. It is necessary to guide electrical cables and purge tubing into the upper end of the camera and lighting subassembly. The support stem and the camera and lighting subassembly are connected, including the electrical cable connections and purge tube connections. The applicable tests, as described in operational test procedure, are performed to ensure the purge gas and camera system are operating before and during installation into the riser.

The crane lift hook is attached to the riser-plug 1 ifting eye, and the existing riser plug is 1 ifted until the riser-plug flange is $45.7 \mathrm{~cm}$ (18 in.) above the riser flange and block in place. The flange gasket is removed and disposed of in accordance with existing procedures. During the time the existing riser plug is propped open, the riser interior is purged of any stagnant gas by inflow of air.

Silicon grease is applied to the rubber sealing surface of the shielding plug removal/installation confinement fixture. The flange blocks are removed and the shielding-plug removal/installation confinement fixture is installed. 
Figure 2-2. Schematic of Support Stand.

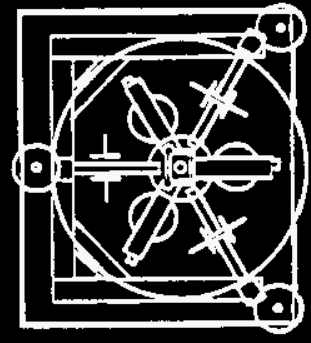

Top View

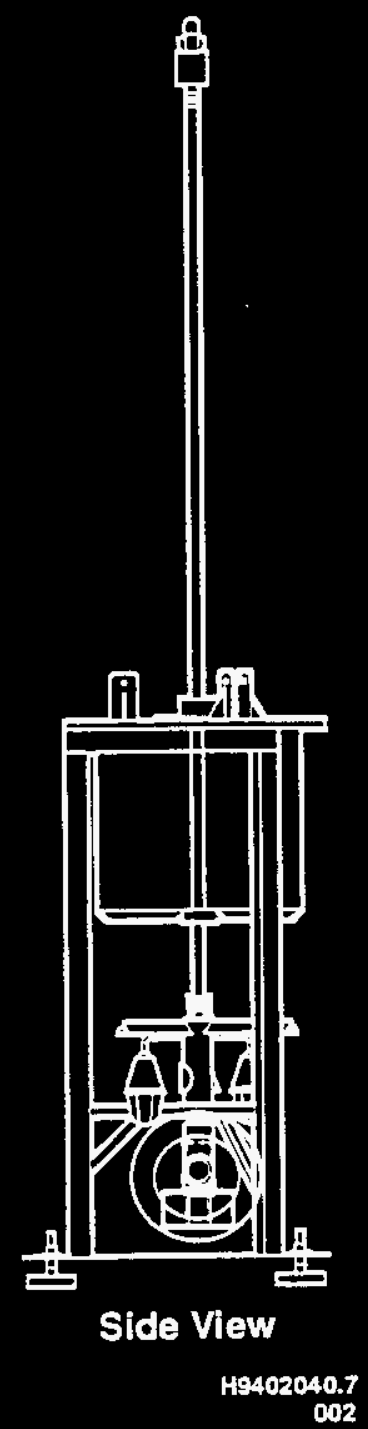


Figure 2-3. Schematic of the Camera and Lights Assembly.

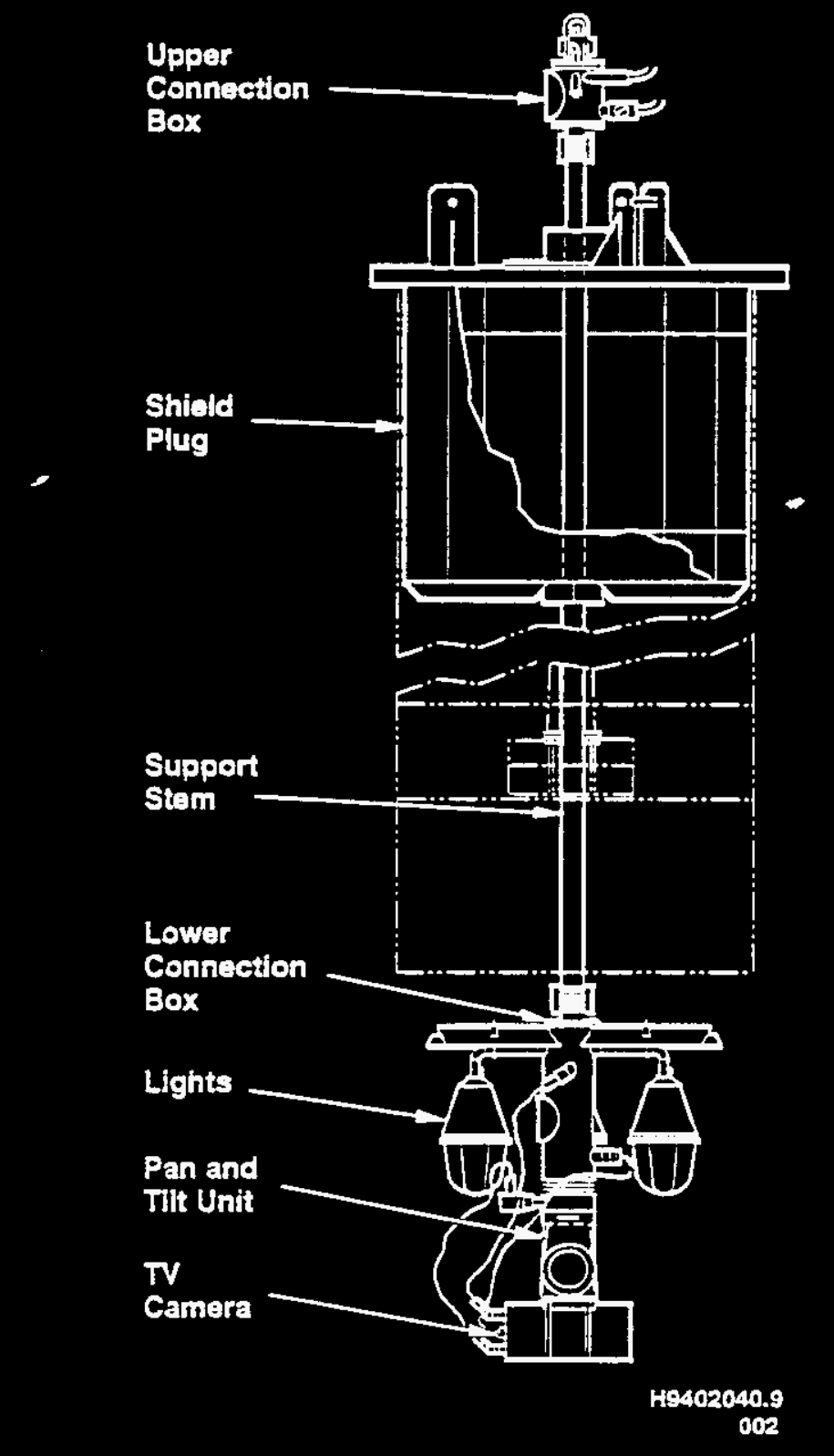


The shielding plug is lifted until the distance between the shielding-plug flange and the riser flange is $1.07 \mathrm{~m}(3.5 \mathrm{ft})$. The sliding riser cover in the shielding-plug removal/installation confinement-seal fixture is closed and the shielding plug is lifted until it clears the shielding-plug removal/installation confinement-seal fixture. A plastic bag is secured to enclose the potentially contaminated riser-shielding plug. The bagged risershielding plug is moved to a designated storage location for possible future reuse.

The electrical grounding/bonding of the camera system and the camerasystem shielding plug is completed and verified in accordance with existing procedure. The crane hook is attached to the lifting eye on the camera system support assembly. The camera system is 1 ifted until it is inside the shielding-plug extension.

Silicon grease is applied again to the rubber sealing surface of the shielding-plug removal/installation confinement-seal fixture. The entire camera system, including the new shielding plug, is lifted and moved over the riser. The crane then slowly lowers the assembiy until the tapered bottom of the shielding-plug extension is just beginning to enter the opening in the shielding-plug removal/installation seal fixture gasket. At this point, the lowering of the camera system should cease and the shielding-plug extension should be centered.

After centering is complete, the system is lowered until the mark on the shielding-plug extension is reached. The lowering of the system is stopped and the sliding plate in the shielding-plug removal/installation confinementfixture is pulled until the "open" mark is reached. The lowering of the camera system is continued until the upper shielding-plug flange is approximately $10.2 \mathrm{~cm}$ (4 in.) from the shielding plug removal/installation seal fixture upper flange. The lowering of the camera system is stopped and the shielding-plug seal fixture is removed from the riser. The lowering of the camera system is continued until the new shielding-plug flange is resting on the riser flange. The flange holes are arranged in the two flanges and the flange bolts are installed as required.

The crane hook is attached to the camera-system support stem and the slack is taken up in the crane cables. The support stem supports are loosened until the support stem can slide through the new shielding plug. The camera is lowered until the operating position is reached as indicated by the mark on bolts are tightened in the split clamp. The crane hook is removed from the camera support. The plug support stand and other installation equipment are moved to a storage location. All fixtures, the original shielding plug, and other potentially contaminated equipment are prepared as required for proper storage.

Removal of the plug and camera system from the riser will reverse the order of the above description.

The newer designs for the closed-circuit television camera and lights assembly involve smaller risers. No precautions to prevent the tank from reaching atmospheric pressure, such as the shield plug removal/installation confinement-seal fixture, are used during installation and removal. The camera and lights assembly is raised and lowered by crane into position. 


\subsubsection{Operation}

Activation of both the camera and lights is made through remote control panels, recorders, and a color monitor located in a trailer outside the SY Tank Farm fence. Control of the purge gas system also will be from the same trailer. No further tank contact is required until the camera and 1 ights assembly is removed.

The purge gas system has dual safety instruments to alarm and automatically shut off all electrical power to the electrical components served by the purge gas system due to loss of gas pressure. One safety instrument is a pressure-indicating transmitter coupled to an alarm light at the control panel; the other safety instrument is a low-pressure switch that will activate an electric supply cutoff relay.

A structural analys is for the camera and light assembly has been performed (Jones 1994b). Jones (1994b) documents the analys is of both a vertical dead-weight lift and a seismic event. The conclusions of Jones (1994b) indicated that the designs were acceptable for the expected dynamic and impact loads.

\subsection{VAPOR-SPACE SAMPLING}

Vapor space sampling is performed to determine the toxic and organic components in addition to any flammable gases in the tank. The main purpose of this sampling is for worker protection.

A sample probe assembly may be temporarily installed in tanks that do not have the gas probe assembly. The assembly has three main components: the sample tubes of Tygon or Tygon-equivalent tubing with a helically wound stainless steel wire encircling the outside; a sampling-riser cover that is a carbon-steel plate predrilled for bolt holes to match the riser flange and holes for the sample ports; and sample ports that are stainless steel tubes extending through the riser cover.

The sample port tubes (a short stainless steel tube that extends on both sides of the riser cover) are connected to the Tygon or Tygon-equivalent sampling tubes on one side; on the other side the tubes are equipped with valves and connections for the sample analysis instrumentation. The wire coil on the sample tubes aids in grounding the probe, for example, by providing a pathway for electrostatic energy to be removed.

One type of sampling instrument used is the combustible- or flammable-gas meter. Two models are generally used. Both models draw the gas sample over a hot wire and measure the change in resistance of the wire to determine the concentrations of flammable gas and oxygen. When oxygen is low or when another oxidizer is present, the meter readout is affected. The gas is burned catalytically around the wire. The burning chamber is protected from the potential of a flame flashback by a sintered filter at the chamber inlet. Each meter has an integral vacuum pump that pulls the sample stream across the

\footnotetext{
"Tygon is a trademark of Norton Company.
} 
hot wire. Both models are 1 isted by Underwriters Laboratories as Classified for use in Class 1, Division 1, Groups A, B (i.e., hydrogen), C, and D (see Appendix $D$ for National Fire Protection Association definitions) applications, in accordance with the National Electrical Code (NFPA 1993).

The organic vapor monitor is used for tank space vapor sampling at the Hanford Site. The meter uses photo-ionization to detect organic molecules and ammonia. The meter has an integral vacuum pump that pulls the sample stream through the meter. The organic vapor monitor is listed by Underwriters' Laboratory for use in Class 1, Division 2, Groups A, B, C, and D applications (NFPA 1993).

The hydrogen sampling cart assembly, and a similar unit called the hydrogen cyanide sampling cart, are modified hand trucks that have a vacuum pump; tubing manifolds with valves for hook up to sample probes; rotometers for measuring gas flows; and sample canisters for grab samples. The vacuum pump assemblies consist of a metal-bellows pump and an electric motor that powers the pump.

Metal-bellows pumps have been used with the standard hydrogen monitoring systems for monitoring and sampling tank 241-SY-101. The compliance of the pump with the requirements of National Fire Protection Association, Inc., Article 70 for use in hazardous locations is documented in Schneider (1992). The pump was assessed for use on tank 241-SY-101 in Deichman (1992). The electric motor is rated Class 1 , Group D (i.e., ammonia, butane, ethane), which is not rated for Group B (hydrogen). Because the motor is in the open air and not in contact with the gas stream, the pump is considered safe in the system.

To install the vapor-space sampling equipment, it may be necessary to remove existing equipment, such as a manual tape, or a Food Instrument Corporation level-indicating device and replace it after the sampling is complete. An alternative is to remove the breather filter and install a $Y$-shaped spool piece. Both the breather filter and the vapor-space sampling equipment would use the same riser. Tanks that have standard hydrogen monitoring cabinets installed on probe assemblies also provide probes for use by the vapor-sampling program.

\subsection{GRAB SAMPLING}

Grab sampling of tank waste is a standard tank farm activity when a sample of tank liquid or sludge is needed. Samples are taken from various depths in the liquid using a specially designed bottle.

A 100-mL glass sampling bottle with a rubber stopper is placed in a 5.1-cm (2-in.) steel pipe sleeve and manually lowered on a stainless steel wire into the waste. The grab sample may be taken in the salt well at the dip tube or any open riser. The weight of the pipe sleeve submerges the bottle. The wire is looped through the top of the rubber stopper and tied to the neck of the bottle. After lowering the bottle to the proper level, a quick jerk removes the rubber stopper and the bottle fills with liquid supernatant. For sludges, a wide-mouthed bottle is used. After a bottle is filled, the bottle is manually pulled to the surface by a worker wearing protective gloves. 
The sampling bottle is placed in an onsite transport cask and transported, in accordance with the approved procedures, to a laboratory for analys is.

\subsection{AUGER SAMPLING}

Auger sampling is employed primarily to investigate waste for potential energetic behavior. Auger samples are taken using a hand-operated device similar to a wood-boring tool. Limited solid samples of the surface of the waste can be obtained by this method of sampling.

The auger sampler uses a guide tube that extends from the top of the riser to the waste surface. A detailed description of the guide tube assembly components, their assembly, and their removal can be found in Van Vleet (1991). Figures 2-4 and 2-5 show schematics of the complete assembly, which may weigh up to $114 \mathrm{~kg}(250 \mathrm{lb})$. In some cases, existing equipment (e.g., the manual tape, the Food Instrument Corporation levelindicating device, or the breather filter) may have to be removed temporarily for the sampling activity. After the sampling is complete, the equipment would be replaced.

\subsubsection{Installation or Removal}

The auger sampler can be installed manually by adding one segment at a time or by crane. At least one lifting bar must be in place at all times during manual installation. Crane installation is performed according to established guidelines. Before installation (either manually or by crane), the adjustable flange is positioned so that the guide tube tip is above the waste surface when the flange is bolted to the riser. Then the assembly is rotated so that the guide tube tip touches the waste surface. The guide tube assembly is disassembled by reversing the installation procedure. All equipment used in this sampling effort has been designed for decontamination and reuse or ease of disposal.

When the guide tube assembly is ready to receive the auger sampler, the retrieval cask (Figure 2-5) is raised manually and attached to the bushing on the guide tube via a connector.

To provide assurance during crane installation that the assembly could not be inadvertently dropped into the tank, the lift is a critical lift. This minimizes the likelihood of frictional heating, mechanical sparks, or impactheating from dropped objects. The assembly then is lowered until the ratelimiting nut is resting on the retrieval container. The assembly is detached from the crane; sampling then is performed. When sampling is complete, the auger assembly is removed using the reverse of the installation process. Segments are placed in plastic bags and packed into $0.21-\mathrm{m}^{3}$ (55-gal) drums for decontamination and reuse or disposal. 
Figure 2-4. Guide Tube Assembly.

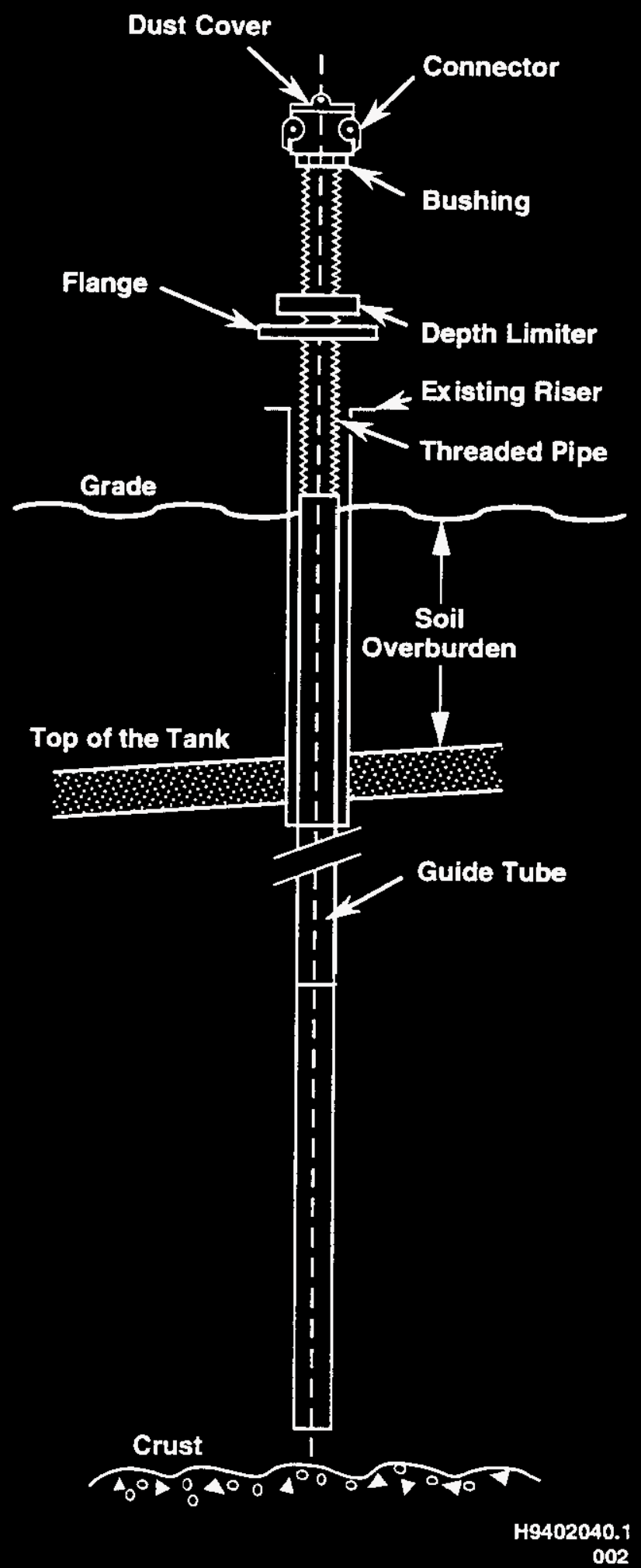


Figure 2-5. Auger Sampler Assembly.

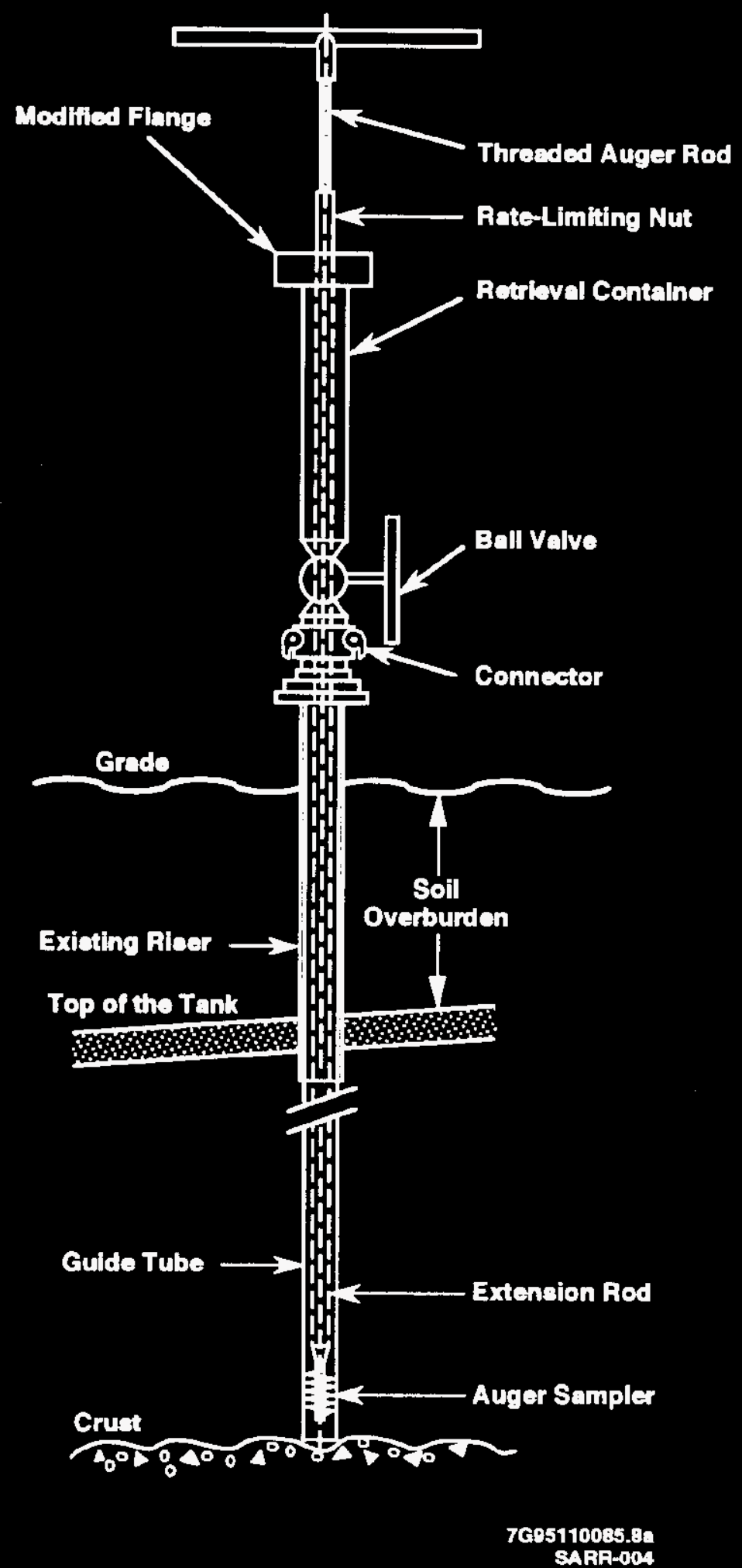




\subsubsection{Description and Operation}

The auger bit is $33.7 \mathrm{~cm}$ (13.25 in.) long with a diameter, not including the flights, of $2.54 \mathrm{~cm}$ ( $1 \mathrm{in}$.) with a bit on one end and a connector on the other end. The entire auger bit has been machined out of a solid, round, 400-series stainless steel bar. The diameter of the auger bit, including the flights, is $5.33 \mathrm{~cm}(2.1 \mathrm{in}$.). Figure $2-6$ provides a schematic of the auger bit.

A floating sleeve covers the auger bit at all times except during sampling. The inner diameter of the floating sleeve is sized to just allow the auger flights to fit. The outer diameter is sized to allow the sleeve to travel freely in the guide tube assembly. The floating sleeve is designed to help ensure sample integrity during retrieval, i.e., crust material cannot fall off the flights while the auger sampler is being removed.

The auger is turned by hand using slow and deliberate motions. The last segment of the auger assembly consists of a threaded rod with a rate- 7 imiting nut and two knurled nuts. The knurled nuts are used as a depth limiter. The rate-limiting nut is designed to fit into the modified flange plate. The threads limit how fast the auger can penetrate the crust. The two knurled nuts are adjusted so that they are up to $25.4 \mathrm{~cm}$ (10 in.) above the rate-1imiting nut. Once the required sample depth of up $25.4 \mathrm{~cm}(10 \mathrm{in}$.) is reached, the auger assembly is manually raised using the "T" handle until the next segment of the extension rod is visible. The auger assembly then is withdrawn from the tank. The last segment is raised so that the auger bit is above the ball valve. The ball valve is closed and the auger bit lowered until it rests on the closed valve. The last segment of the auger extension rod is removed. The retrieval container is removed from the connector on the guide tube. The retrieval container is placed in an onsite transport cask and transported, in accordance with the approved procedures, to a laboratory for analysis.

\subsection{PUSH-MODE CORE SAMPLING}

While auger sampling allows a surface sample to be taken, push-mode core sampling is effective in retrieving sludge, cohesive solids, and liquids from a full-depth sample.

A core sampling truck provides the means to take a full-depth sample. A truck can operate in two modes: push mode and rotary mode. In push mode, the core sample is taken using hydraul ic pressure to push the samplers through the waste. This works well for soft waste materials. For hard waste materials, other means of sampling may be required.

A rotary platform is mounted on the rear of the core sampling truck. Two sets of equipment are mounted on the rotary platform. One set is the shielded sample receiver unit that is used to place empty samplers into and remove full samplers from the drill string. The other set is the drill unit that is used to push the drill string and sampler into the material being sampled. A control console and electric hoist also are mounted on the rotary 
WHC-SD-WM-SARR-002 REV 1

Figure 2-6. Schematic of the Auger Bit.

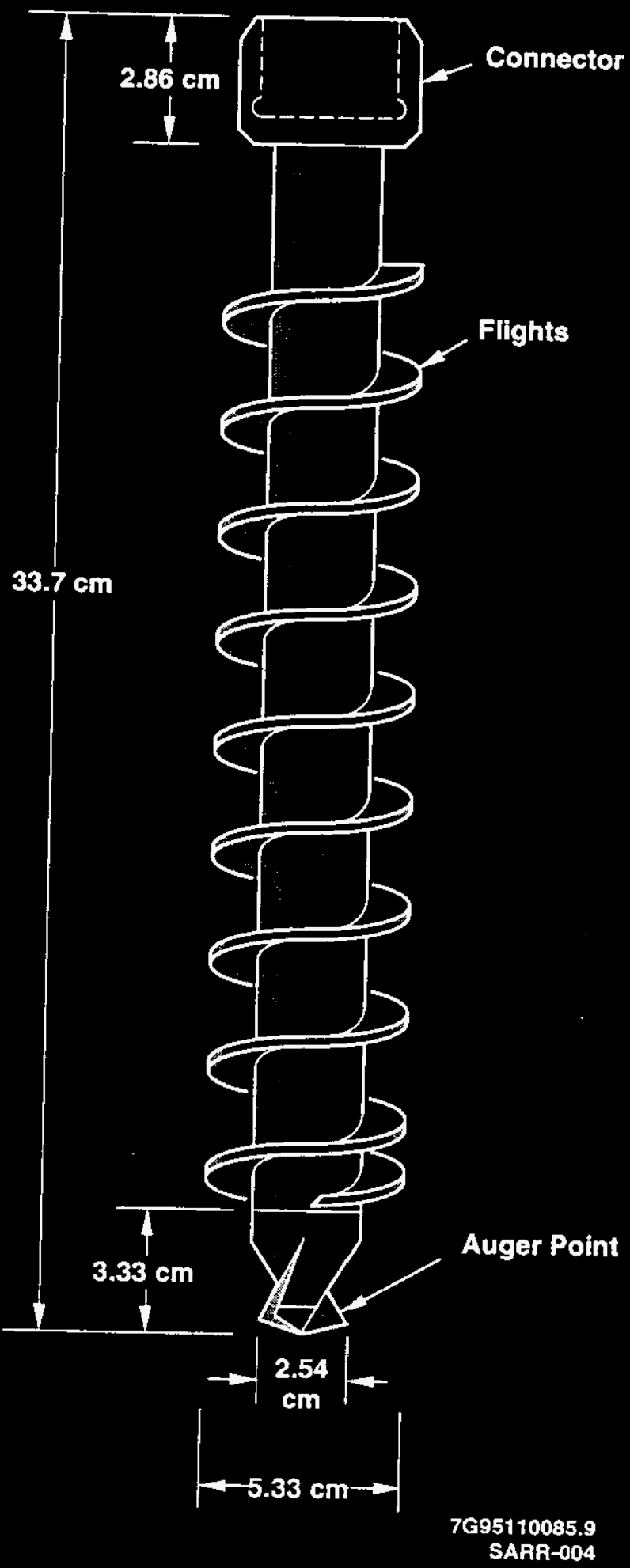


platform. Figure 2-7 shows a schematic of the core drill truck. Figures 2-8 and 2-9 show additional details. The following paragraphs briefly summarize the sampling procedure. A more detailed description can be found in Marusich (1991a) and Milliken (1995).

In some cases, existing equipment, e.g., the manual tape, the Food Instrument Corporation level-indicating device, or the breather filter, may have to be temporarily removed for the sampling activity. After the sampling is complete, the equipment would be replaced.

\subsubsection{Installation}

The first step of the installation process is to set up the equipment. The core drill truck is positioned over the chosen riser. The truck is leveled and the riser adapter, spray washer assembly, and pneumatic foot clamp are installed (see Figure 2-8b). The pneumatic foot clamp provides one of the physical restraints to prevent the drill string from being dropped into the tank during installation and removal. At that time, the truck is ready to perform core sampling.

\subsubsection{Operation}

To perform the sampling, the first core sampler is inserted into the drill string core barrel. The drill string is attached to the core barrel and then extended a section at a time. An electronic hoist and the pneumatic foot clamp are used to insert or remove the drill string. The drill string is lowered into the tank using the hoist, the pneumatic foot clamp is activated to physically restrain the drill string, and the hoist is disengaged. Then a new section of drill string is threaded onto the existing drill string, the hoist is reattached (providing a physical restraint to dropping the drill string), and the foot clamp is disengaged. This continues unt il the sampler is just above the surface of the waste. The distance to the surface of the waste is determined by using a manual tape and the drill string length work sheets specified in the work plan. The drill unit is attached to the drill string; the drill is not be rotated. Rotation is prevented by placing the drill speed control lever in neutral and installing a multilock device to prevent movement of the drill speed control lever. The device requires that both locks be removed before the drill speed control lever is accessed. The drill unit then pushes the drill string $48 \mathrm{~cm}$ (19 in.) into the waste (see Figures $2-9 b$ and $2-9 c$ ). A rotary valve is closed at the bottom of the sampler (see Figure 2-9d), hydrostatic fluid is added inside the drill string to prevent waste from filling the drill string while the sampler is removed and a new sampler is installed, and the drill string is detached from the drill unit.

The platform is rotated so that the shielded receiver (see Figure 2-8a) is over the drill string. The sampler is raised into the shielded receiver. A ball valve is closed at the bottom of the shielded receiver. A cap with an absorbent sponge is attached to the bottom of the shielded receiver. The platform is rotated to position the shielded receiver over the empty transfer 
WHC-SD-WM-SARR-002 REV 1

Figure 2-7. Schematic of the Core Drill Truck.

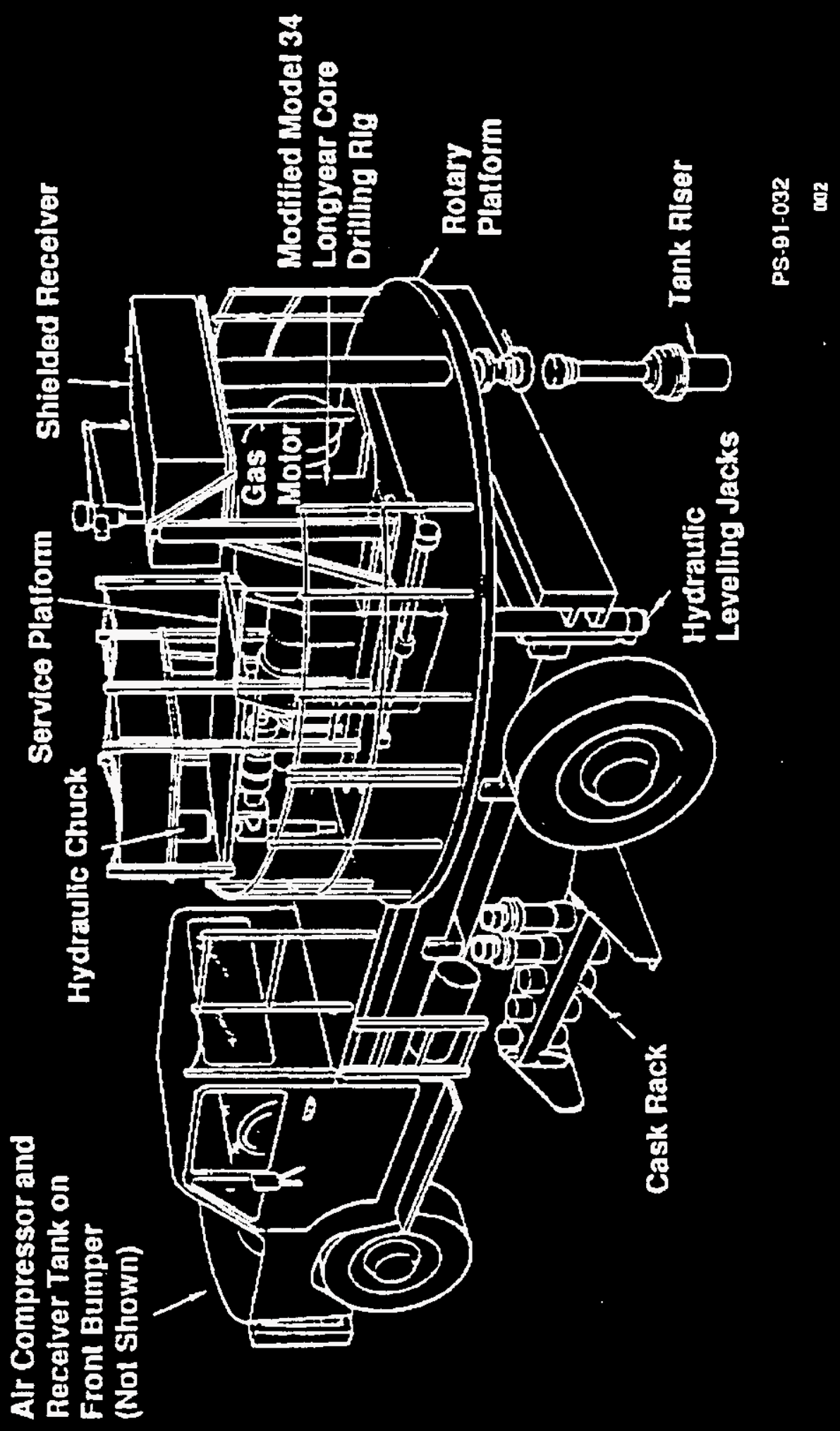


Figure 2-8. Shielded Receiver and Associated Equipment.

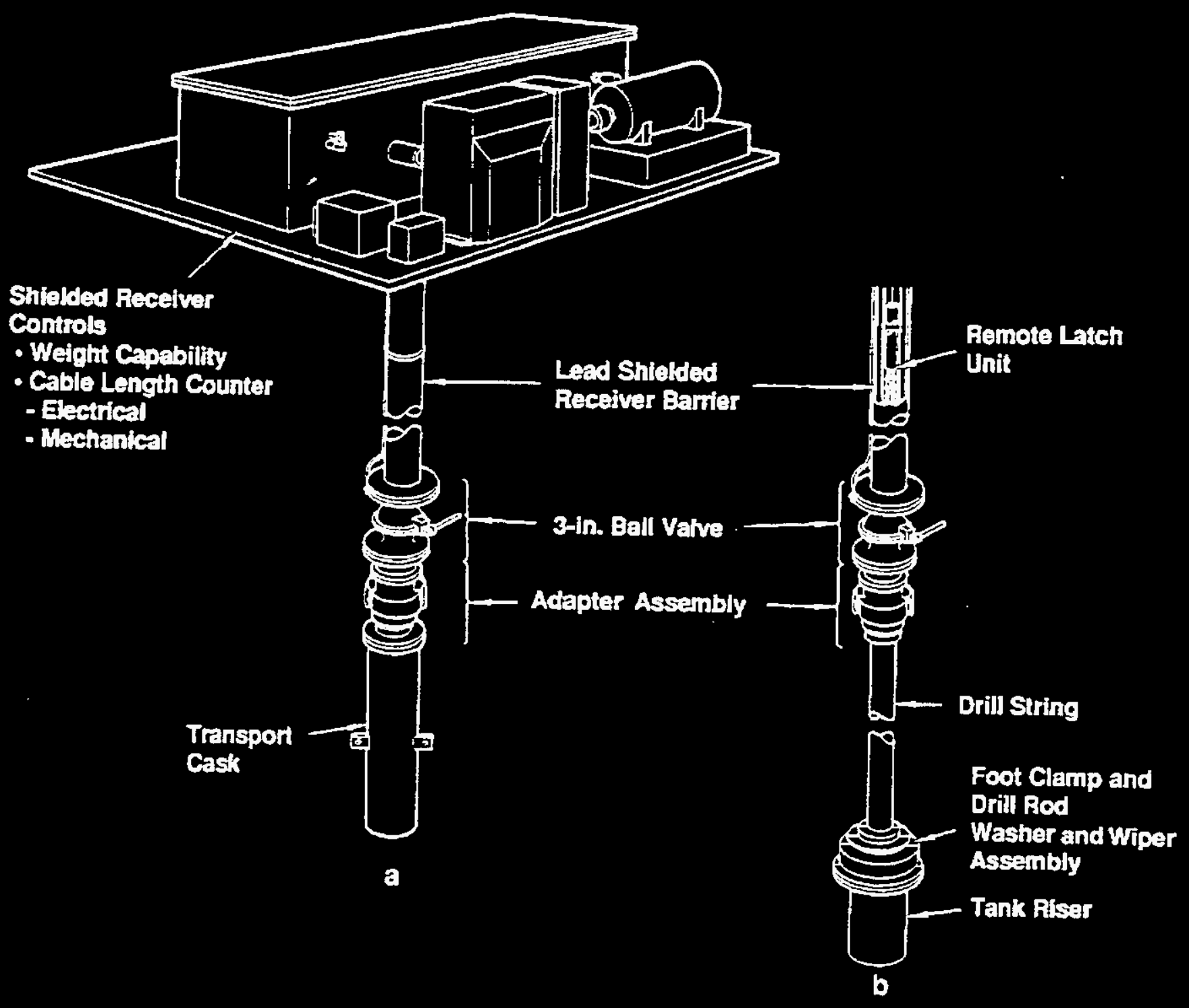

P38402.11

PS-91-034 
Figure 2-9. Core Sampler Assembly in the Drill String.

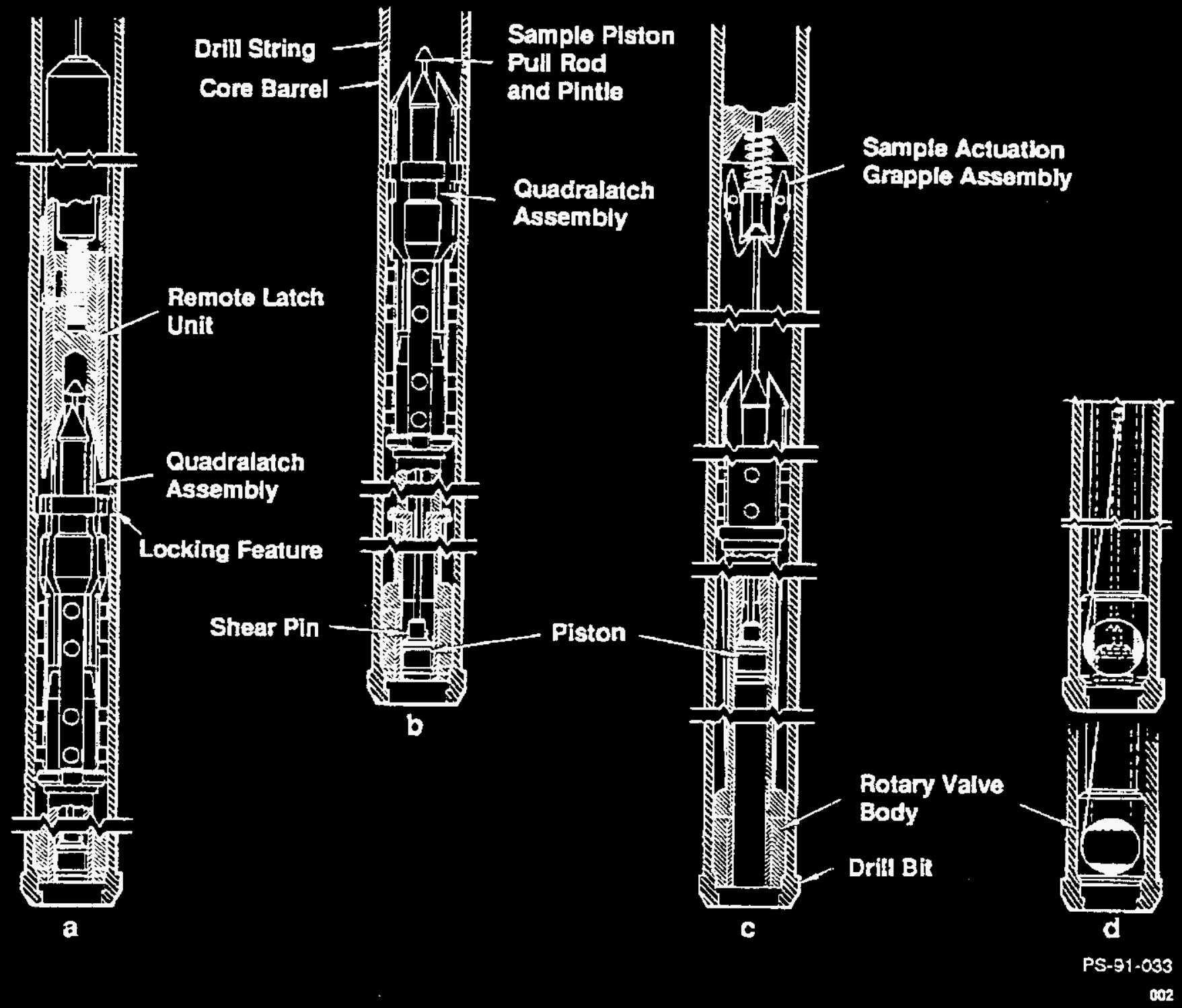


cask. The cap is removed and the sampler is lowered into the transfer cask. A new sampler is placed in the core barrel (See Figure 2-9a). The total process is repeated until a full core sample is obtained.

\subsection{INSTALLATION OF NULTIFUNCTION INSTRUMENT TREE}

The purpose of the multifunction instrument tree is to provide a physical support to a variety of in-tank instrumentation. This multifunction instrument tree is attached to a riser cap which is designed to maintain tank containment.

The multifunction instrument tree usually contains 22 thermocouples, 2 strain gages, and 6 gas sampling tubes. Installation is made using a water jet. The jets are for penetration through any salt cake that may be present. These are only used during the installation of the instrument tree.

\subsubsection{Instrument Tree Background}

Schematic diagrams of the multifunction instrument tree are shown in Figures 2-10, 2-11, and 2-12. The multifunction instrument tree is made from concentric 300-series stainless steel tubes with outside diameters of $5.38 \mathrm{~cm}$ (2.12 in.) on the inner tube and $8.89 \mathrm{~cm}(3.5 \mathrm{in.})$ on the outer tube. The outer tube is $0.48-\mathrm{cm}-(0.187-\mathrm{in} .-)$ thick $304 \mathrm{~L}$ stainless steel. The mult ifunction instrument tree is $17.86 \mathrm{~m}(58.6 \mathrm{ft})$ long, and weighs about $420 \mathrm{~kg}(926 \mathrm{lb})$. Six $0.99-\mathrm{cm}-(0.39-\mathrm{in} .-)$ diameter stainless steel tubes are positioned within the annulus and extend into the terminal head.

Twenty-two thermocouples are welded on the inner surface of the outer tube in $3.18-\mathrm{cm}(1.25-\mathrm{in}$.$) by 3.81-\mathrm{cm}(1.5-\mathrm{in}$.) windows thinned to $0.165 \mathrm{~cm}$

$(0.065$ in. $)$. Thermocouple wires extend through the annulus between the tubes into the terminal head at the top of the multifunction instrument tree.

Safety evaluations were completed to install the two multifunction instrument trees in tank 241-SY-101 (Christensen 1992; Van Vleet 1993b).

Two strain gauges are spot welded on the inner multifunction instrument tree tube at a prespecified location from the bottom end. The gauges are attached by insulated wire to the 55-pin connector in the multifunction instrument tree enclosure head.

Three of the six annulus tubes are used for gas sampling the vapor space of the waste tank; one is used for measuring the gas pressure of the waste tank, and two are used for carrying jetting water to a water jetting insertion nozzle at the bottom of the multifunction instrument tree. During installation positive water pressure in the water tubes during installation will prevent backflow of waste. After installation, small amounts of liquid waste may diffuse into the water-filled tubes through the $0.32-\mathrm{cm}(0.125-\mathrm{in}$.) nozzle openings; however, this would create no adverse effects because the water tubes are sealed from all other spaces within the multifunction instrument tree. Check valves at the top of the water tubes will prevent any release of gases after installation.

The jetting nozzle has a flat face and is the same diameter, $8.89 \mathrm{~cm}$ (3.5 in.), as the outer diameter of the multifunction instrument tree. The 
Figure 2-10. Multifunction Instrument Tree Cross Section.

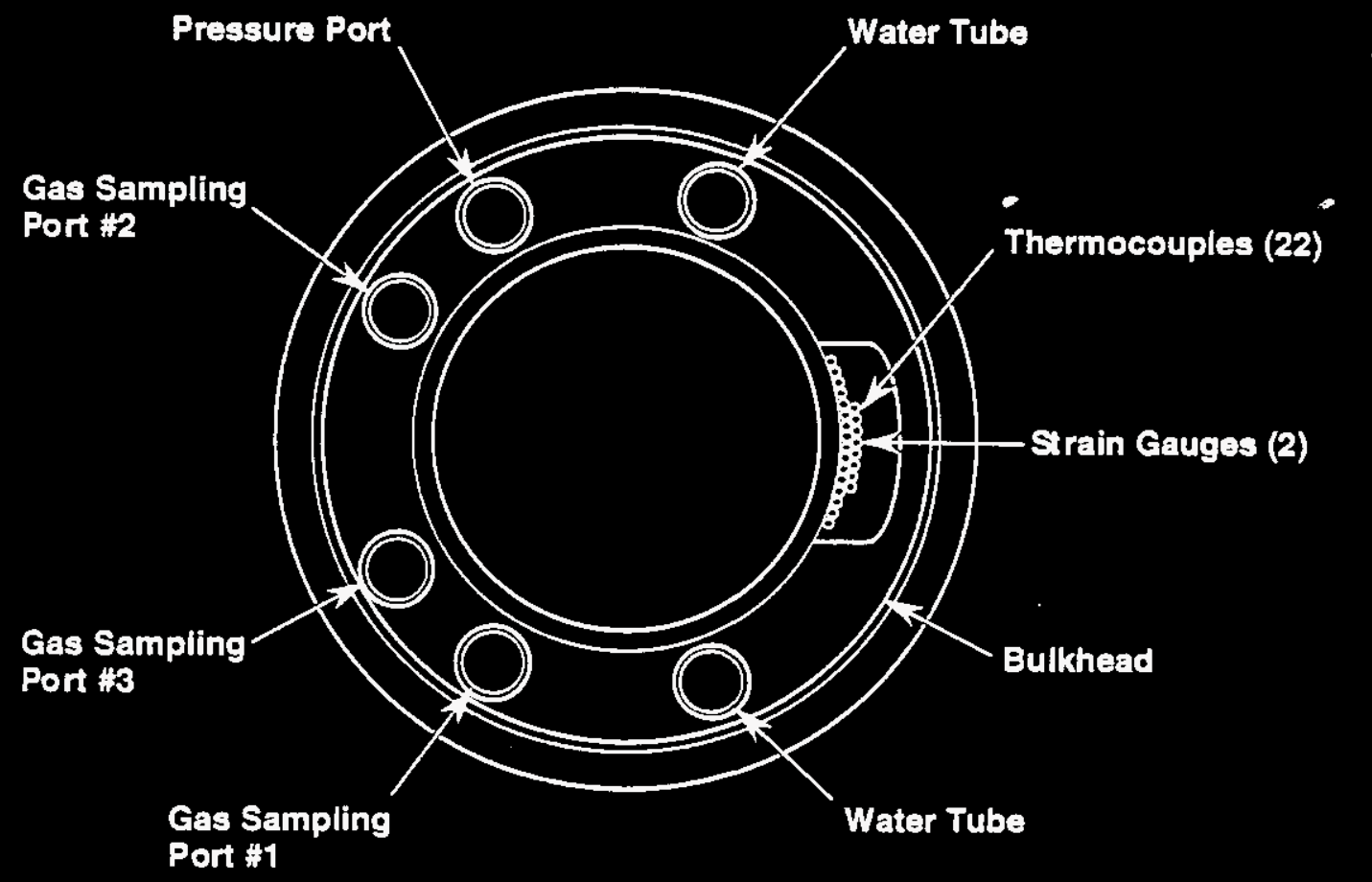


Figure 2-11. Multifunction Instrument Tree Schematic.

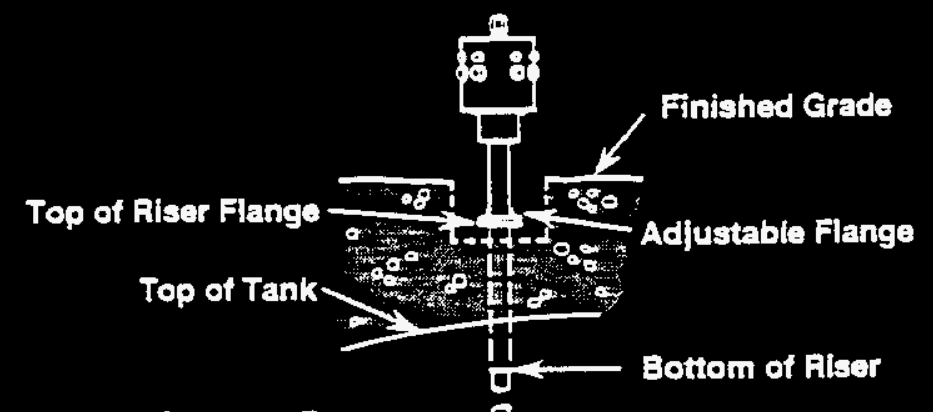

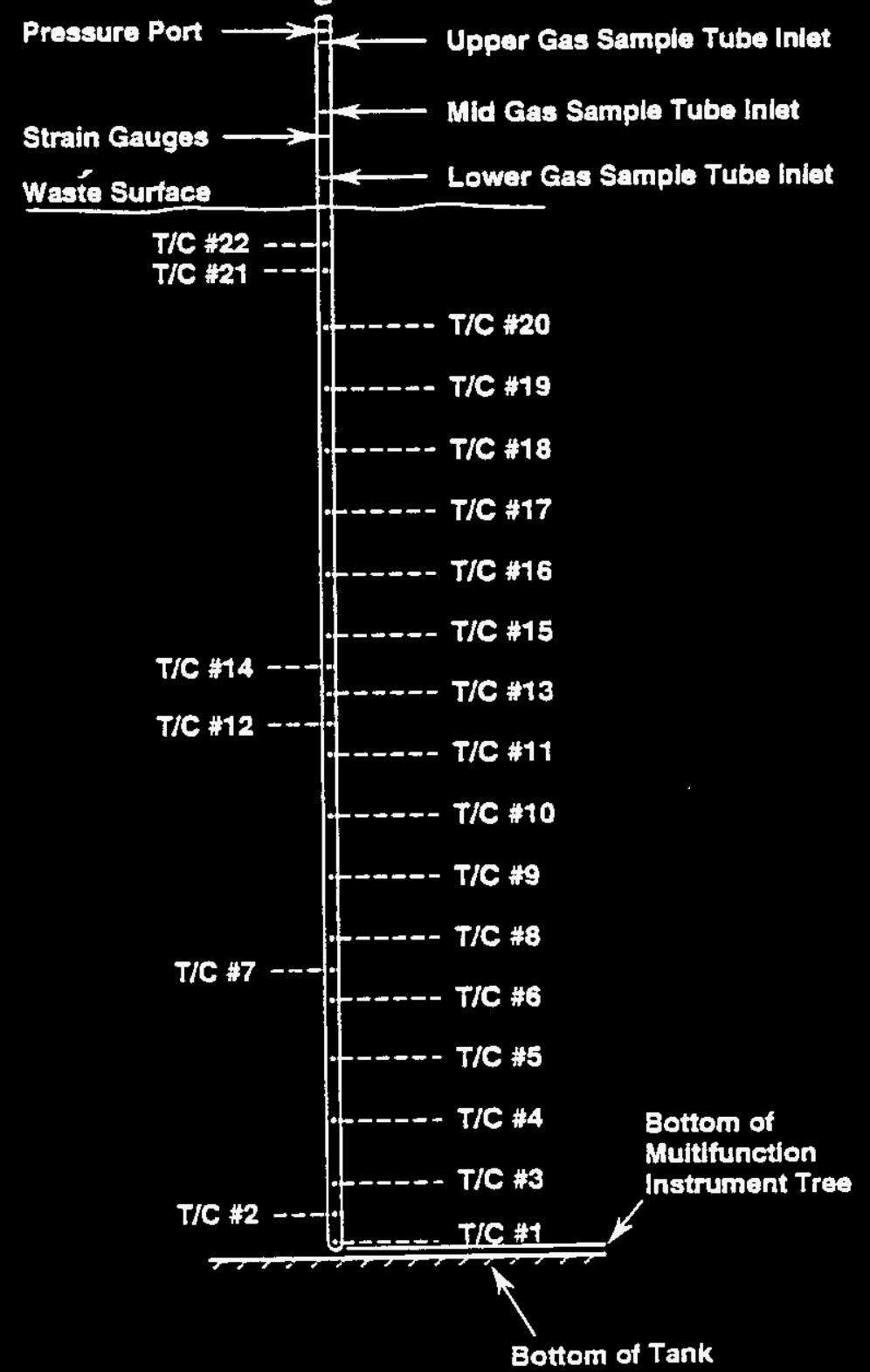




\section{WHC-SD-WM-SARR-002 REV 1}

Figure 2-12. Schematic of Connections to the Multifunction Instrument Tree

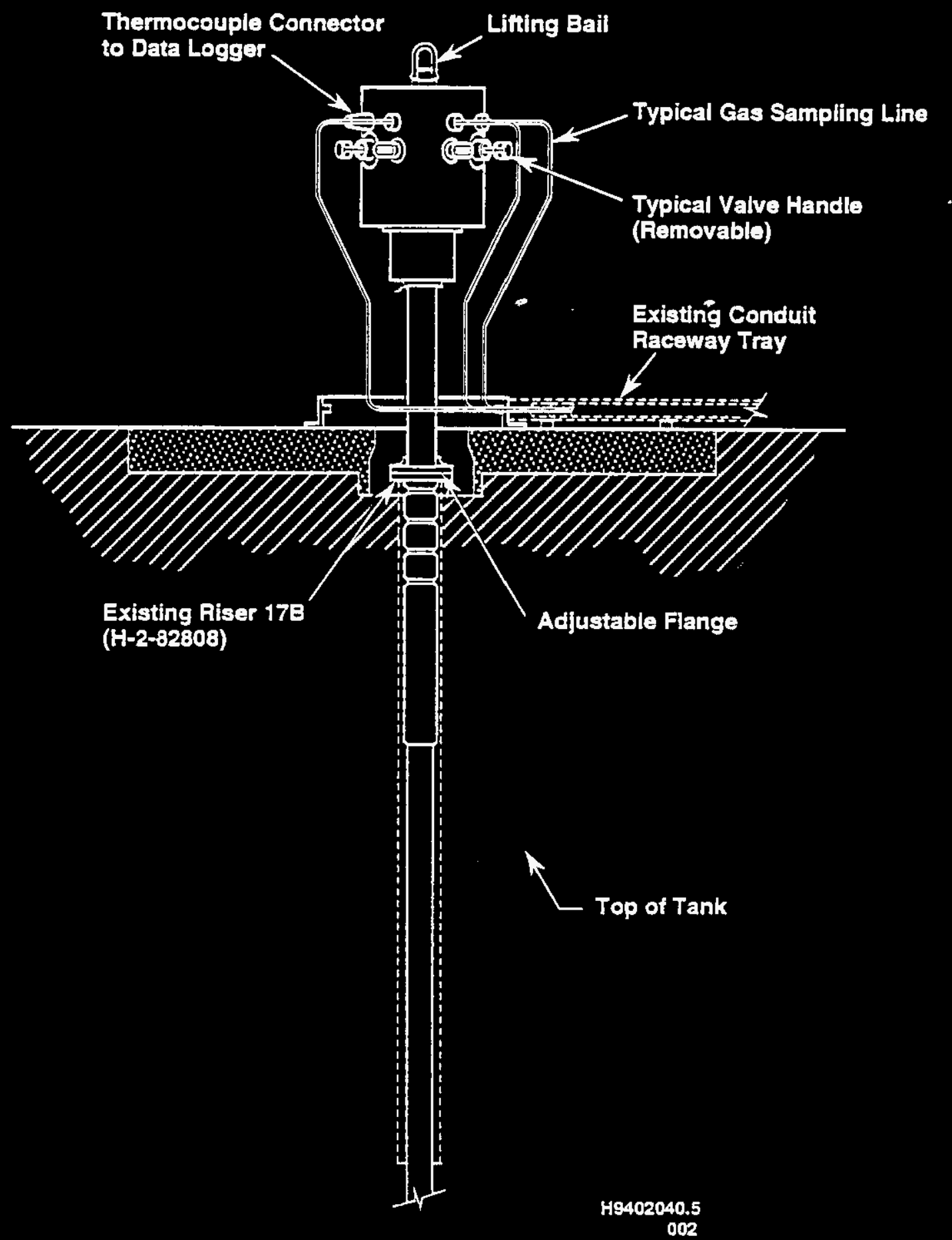


nozzle contains several small holes to inject warm water radially outward from the bottom of the multifunction instrument tree at 0.19 to $0.50 \mathrm{~L} / \mathrm{second}$ ( 3 to $8 \mathrm{gal} / \mathrm{min}$ ) at a supply pressure of 414 to $862 \mathrm{kPa}(60$ to $125 \mathrm{psi})$. The jetted water is used to dissolve and/or displace tank waste in a small area around the nozzle to permit the insertion of the multifunction instrument tree downward through the waste.

The gas sampling tubes extend through the multifunction instrument tree terminal head to block shutoff valves exterior to the head. These valves permit hookup of gas monitoring systems to the multifunction instrument tree sampling tubes.

\subsubsection{Installation}

Multifunction instrument tree installation requires an open tank riser during installation. An evaluation of this potential is included in Chapter 4.0.

Before installation of the multifunction instrument tree in a tank, the chosen riser must have any equipment removed, e.g., the temporary gas sampling tubes. After any existing equipment is removed, an aluminum plug gauge is inserted temporarily into the riser to test if the riser is straight and of appropriate diameter $(10.2 \mathrm{~cm}[4 \mathrm{in.}])$ to receive the multifunction instrument tree.

The multifunction instrument tree may be transported to the tank by a flatbed truck. During transport, it may be held rigid by a shipping carton. At the tank the multifunction instrument tree is lifted to a vertical position by a hydraulic-type crane lifting on the top lifting bail and a temporary clamp that is $4.3 \mathrm{~m}$ (14 ft) below the lifting bail. Once the multifunction instrument tree is vertical, the crane will swing it over the open riser and proceed to slowly lower it into the tank until the temporary clamp is within reach of workers. The temporary clamp will then be removed. The crane will continue to slowly lower the tree to about $30.5 \mathrm{~cm}(1 \mathrm{ft})$ above the waste surface. Jetting water is turned on at this point before proceeding with insertion of the multifunction instrument tree through the waste. Penetration rates are expected to be about $30.5 \mathrm{~cm} / \mathrm{min}(1 \mathrm{ft} / \mathrm{min})$.

After multifunction instrument tree installation, the thermocouples and strain gauges are hooked up to a monitoring system. The gas sampling tubes and vapor pressure instrumentation may be hooked up to a standard hydrogen monitoring system.

\subsubsection{Operation}

Millivolt potentials from the thermocouples are converted to $4-$ to 20-milliamp signals by a conditioner at the head of the multifunction instrument tree. The conditioner operates from 12 to 15 volts DC, converted from 110 volts $A C$. The 110 volts $A C$ is isolated from the conditioner by physical distance, a transformer, and other electronic components; thus, there is no possibility of shorting 110 volts to the conditioner. 
Each of the 22 thermocouples can be read manually through a rotary selection switch at the instrumentation trailer. In auto mode, all 22 thermocouple signals can simultaneously be routed to the data logger, which may be located in a nearby building and/or in building 2750-E, i.e., the Computer Automated Surveillance System.

Jones (1994a) documents the structural analys is evaluation of the multifunction instrument tree. It documents the seismic analysis, and concludes that the dynamic loads are acceptable.

\subsection{ROUTINE MAINTENANCE}

Activities with no direct communication with the tank vapor space or primary tank ventilation system (e.g., measurements for dome subsidence, taking instrument readings) may have different controls than the controls for intrusive activities in flammable gas tanks. For example, if the equipment is isolated from the vapor space or the ventilation system by an isolation valve, bonding generally is not required.

The following are preventive maintenance activities. They are necessary to maintain the tank ventilation system and monitoring equipment in their optimal configurations. This ensures that the tank remains operable and helps maintain the safety basis.

\subsubsection{Ventilation and Balance Activities for Tanks}

One required activity on tanks containing active ventilation is testing the high-efficiency particulate air filters to measure the filtration efficiency of either a single filter or a bank of filters. This involves removing the aerosol test plugs located both upstream and downstream of the filter or filter bank. A nonflammable aerosol is then injected into the ventilation duct through the upstream aerosol port. A penetrometer photometer is placed in the downstream aerosol port; it measures the amount of aerosol exiting the filter. On completion of the measurements, the penetrometer probe is removed and both the upstream and downstream aerosol test plugs are replaced. If the aerosol testing indicates that the filter is breached or plugged, the high-efficiency particulate air filter is changed.

Air flow is measured to determine the rate and distribution of exhaust flow within the ventilation ducting. Typically, flow rate and distribution measurements are made within the ventilation system exhaust stacks and in each tank exhaust header. The measurement is made by removing an access port plug, inserting a pitot tube, and traversing the ventilation duct cross section with the pitot tube. At prescribed intervals, the pressure reading from the pitot tube is recorded. The pressure reading is used to calculate equivalent flow velocities. These calculated velocities are then integrated to determine the total volumetric flow rate of the gas passing through the ventilation duct. On completion of the required measurements, the pitot tube is removed and the access port plug is replaced. 
Psychrometric readings, i.e., the temperature and humidity of the exhaust vapors leaving the tank, are also measured as the need arises. An access port plug is removed and ambient wet and dry bulb temperatures are measured within the ventilation duct and recorded. On completion, the access port plug is replaced.

\subsubsection{Instrument Testing, Calibration, and Repair or Replacement}

Repair or calibration of instruments in the active ventilation system requires disconnecting the instrument 1 ines from the tank to the instrument cabinets. After the instrument lines are disconnected, the instruments are tested, calibrated, and repaired or replaced. Instrument lines are generally $0.64 \mathrm{~cm}(0.125 \mathrm{in}$.$) in diameter. While the instruments are disconnected there$ is a direct opening into the tank. Sampling lines may range up to $2.54 \mathrm{~cm}$ ( 1 in.) in diameter. Sampling equipment is then tested, calibrated, and repaired or replaced. Again, while the sampling equipment is disconnected, there is a direct opening into the tank. However, when the ventilation system is operating, all airflow is into the tank or the ventilation duct because the ventilation system operates at negative pressure. After testing, the instruments and sampling equipment are reconnected to the tank and/or ventilation system. NOTE: If the equipment is isolated from the vapor space or the ventilation system (either passive or active) by an isolation valve, bonding generally is not required.

\subsubsection{Level-Indicating Device Flushing, Repair, or Replacement}

Accumulation of an icicle or lollipop shaped salt crystal deposit on the plummet of the level-indicating devices is a common occurrence. Most Food Instrument Corporation devices are equipped with a water flushing ring assembly to remove the deposit as the measuring tape is reeled into the housing. Flushing water is supplied from the tank farm water supply or a tank truck.

Most manual-tape level-indicating devices and a few Food Instrument Corporation devices do not have a flushing ring assembly. These are flushed by opening a port on the housing and inserting a water hose. Water is supplied from the tank farm water supply or a tank truck.

Up to 758 L (200 gal) of water are used each time to flush the salt crystals off the plummet of level-indicating devices. Adding water to the tank because of routine maintenance is an allowed operation, but is to be minimized.

Some repair activities on the level-indicating devices involve opening the device housing, which is mounted on a tank riser. This is required for removing or replacing electrical boards on Food Instrument Corporation devices; and for removing or replacing metal tapes, tape reels, or plummets on Food Instrument Corporation devices or manual-tapes. 
Other activities can include replacing the entire level-indicating device (housing and contents) with a similar system, or a new type device (e.g., Enraf displacement gauge). In addition, new or old type level-indicating device may be installed on risers not presently containing a device.

The Enraf gauge works by measuring the tension in a wire supporting a displacer (a cone-shaped plummet), which rests on the waste surface. Changes in the surface level are detected by changes in the tension in the wire. The Enraf assembly is installed on a riser spool piece containing an isolation valve, a flushing ring assembly, and a sight glass. The Enraf system may also be equipped with a pressure sensor to monitor the pressure in the tank.

After the Enraf displacer is reeled into the Enraf housing and the isolation valve closed, the Enraf housing is isolated from the tank vapor space, and repair or replacement of items in the housing may be performed without vapor space flammable gas controls. 


\subsection{IDEXTIFICATION OF HAZARDS}

Potential hazards, equipment failures and ignition sources associated with the activities in double-shell tanks with flammable gas concerns are identified in Table 3-1. Table 3-1 also 1 ists the potential results and conditions, necessary safety controls, and cites reference information. An evaluation of each hazard is covered in Chapter 4.0 .

Waste intrusive activities have triggered gas release events in double-shell tanks. To date, these have been small releases (less than $28.3 \mathrm{~m}^{3}$ or $1,000 \mathrm{ft}^{3}$ ). The released gas contains flammable gases such as hydrogen, ammonia, methane, and carbon monoxide along with oxidizers (oxygen and nitrous oxide) and the activity is capable of producing a spark source. Table 3-1 identifies these and other potential results and conditions. Consequences are calculated and reported in Chapter 5.0. 
Table 3-1. Evaluation of Hazards for Double-Shell Tanks with Flammable Gas Concerns. (4 sheets)

\begin{tabular}{|c|c|c|c|}
\hline I tens addressed & Potential results/conditions & Safety controls & Reference information \\
\hline $\begin{array}{l}\text { Electrostatic spark } \\
\text { Electric spark from in-tank } \\
\text { equipment }\end{array}$ & $\begin{array}{l}\text { Ignites } \mathrm{fl} \text { ammable gases if present in } \\
\text { sufficient concentrations to support } \\
\text { combustion. } \\
\text { I gnites flammable gases if present in } \\
\text { sufficient concentrations to support } \\
\text { combustion. }\end{array}$ & $\begin{array}{l}\text { (1) Electrostatic grounding and } \\
\text { bonding. } \\
\text { (2) Ventilation system operable. } \\
\text { (3) Riser purged before act ivity. } \\
\text { (4) Continous monitoring of flamable } \\
\text { gases by two separate independent } \\
\text { moni tors is required. } \\
\text { Exist ing equipment in the tanks has } \\
\text { been evaluated and shown to be able to } \\
\text { operate in a flammable atmosphere or it } \\
\text { has been deenergized. } \\
\text { New equipment must be designed for } \\
\text { flammable atmospheres. }\end{array}$ & $\begin{array}{l}\text { See Section } 4.1 \text { and } \\
\text { WHC-SO-W-SAD-003 } \\
\text { (Marusich et al. 1991) }\end{array}$ \\
\hline $\begin{array}{l}\text { Mechanical spark or frictional } \\
\text { heat during installation or } \\
\text { removal }\end{array}$ & $\begin{array}{l}\text { Ignites flammable gases if present in } \\
\text { sufficient concentrations to support } \\
\text { combustion. }\end{array}$ & $\begin{array}{l}\text { Instal lation or removal occurs when } \\
\text { flammable gas concentrations capable of } \\
\text { support ing combustion are not present } \\
\text { initially and conditions are } \\
\text { continuously monitored during activity. }\end{array}$ & See Sections 4.2 and 4.4. \\
\hline $\begin{array}{l}\text { Failure } \\
\text { (1) Standard hydrogen } \\
\text { monitoring system }\end{array}$ & (1) Loss of hydrogen monitoring. & $\begin{array}{l}\text { (1) Cont inuous monitoring of } f \text { lammable } \\
\text { gases by two separate independent } \\
\text { monitors is required for work to } \\
\text { cont inue. }\end{array}$ & $\begin{array}{l}\text { (1) See Sections } 4.3 .1 \text { and } \\
6.1 .3 \text {. }\end{array}$ \\
\hline (2) Camera & (2) No photographs of inside of tank. & $\begin{array}{l}\text { (2) Wone needed. Inspection of the } \\
\text { waste is not required. }\end{array}$ & (2) See Section 4.3.2. \\
\hline (3) Video Camera & $\begin{array}{l}\text { (3) No video surveillance of the } \\
\text { inside of tank. }\end{array}$ & $\begin{array}{l}\text { (3) None needed. Inspection of the } \\
\text { waste is not required. }\end{array}$ & (3) See Section 4.3.2. \\
\hline (4) Instrument tree & $\begin{array}{l}\text { (4) Loss of temperature and possibly } \\
\text { gas measurements. }\end{array}$ & $\begin{array}{l}\text { (4) Temperature measurements are } \\
\text { required from at least one } \\
\text { thermocouple in the waste. }\end{array}$ & $\begin{array}{l}\text { (4) Single-shell tank Interim } \\
\text { Operational Safety } \\
\text { Requi rements. }\end{array}$ \\
\hline (5) Auger sampling & (5) No sample to analyze. & $\begin{array}{l}\text { (5) None needed due to design and } \\
\text { operation. Grab sampl ing may be } \\
\text { used if auger sampl ing fails. }\end{array}$ & $\begin{array}{l}\text { (5) See Sections } 4.3 .4,6.2 .6 \\
\text { and 6.2.7. }\end{array}$ \\
\hline (6) Push-mode sarrpl ing & (6) No sample to analyze. & $\begin{array}{l}\text { (6) None needed. Broken components } \\
\text { can be replaced and sample } \\
\text { retaken. }\end{array}$ & $\begin{array}{l}\text { (6) See Sections } 4.3 .5 \text { and } \\
6.2 .8 \text {. }\end{array}$ \\
\hline
\end{tabular}




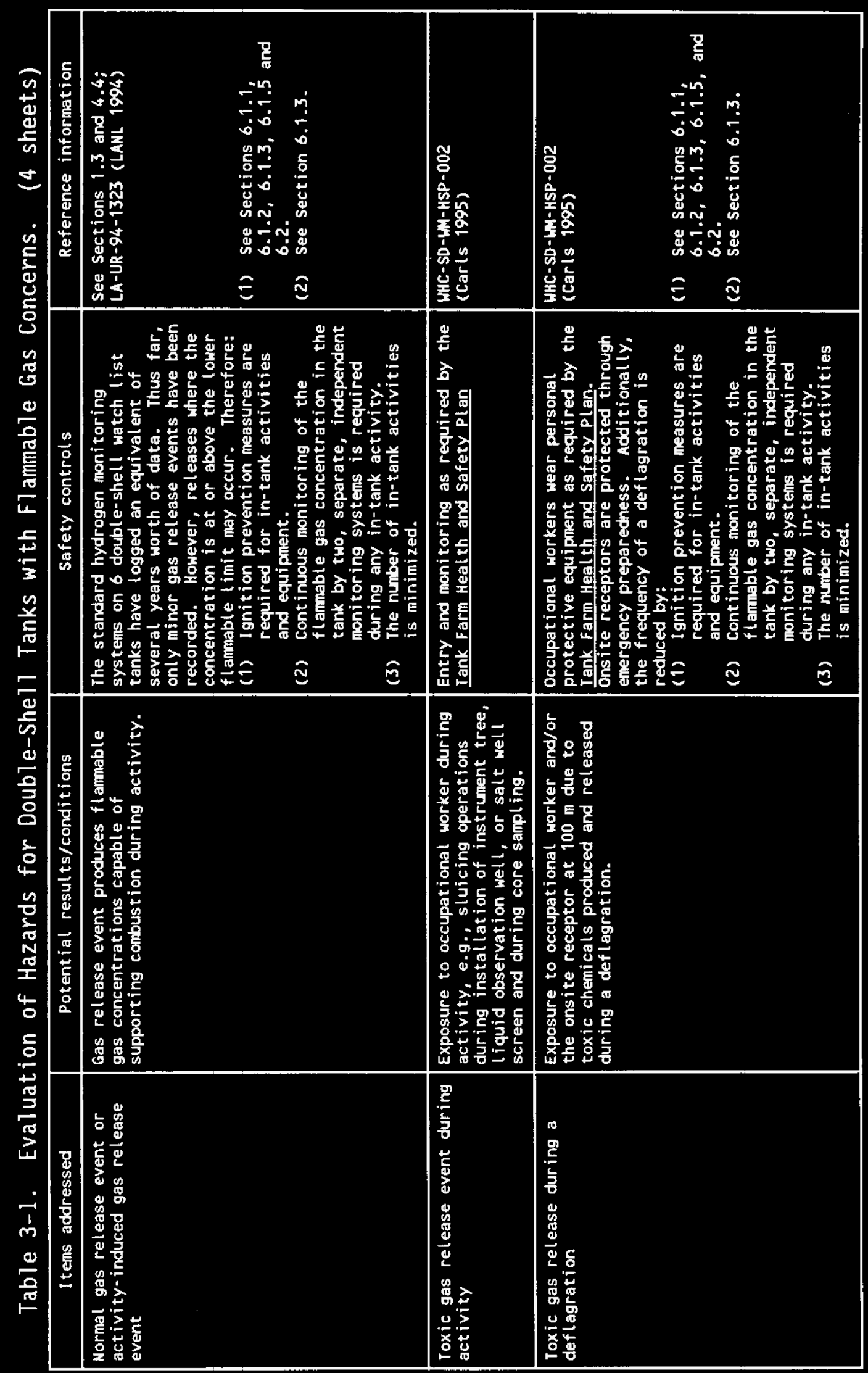


Table 3-1. Evaluation of Hazards for Double-She1l Tanks with Flammable Gas Concerns. (4 sheets)

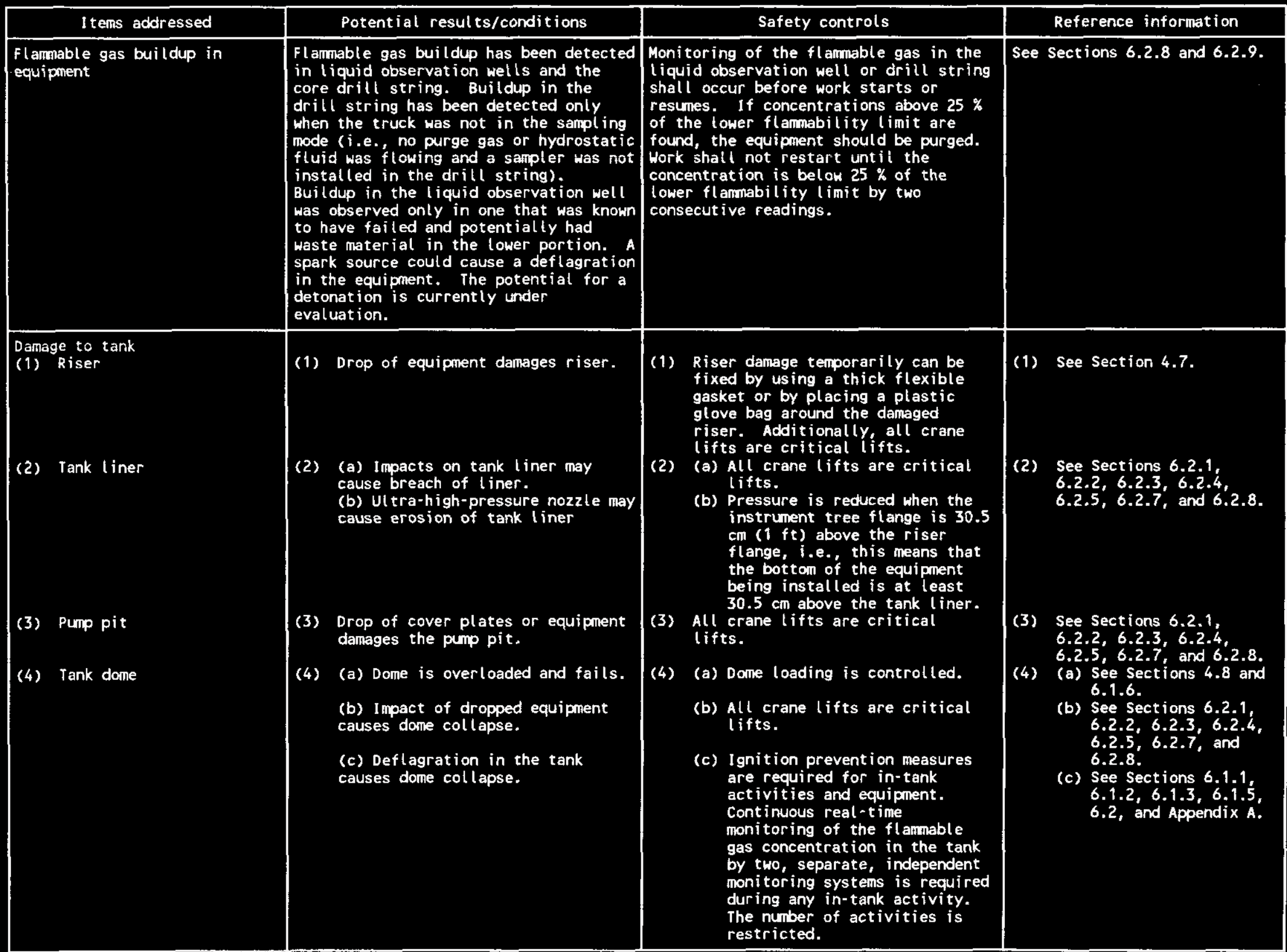




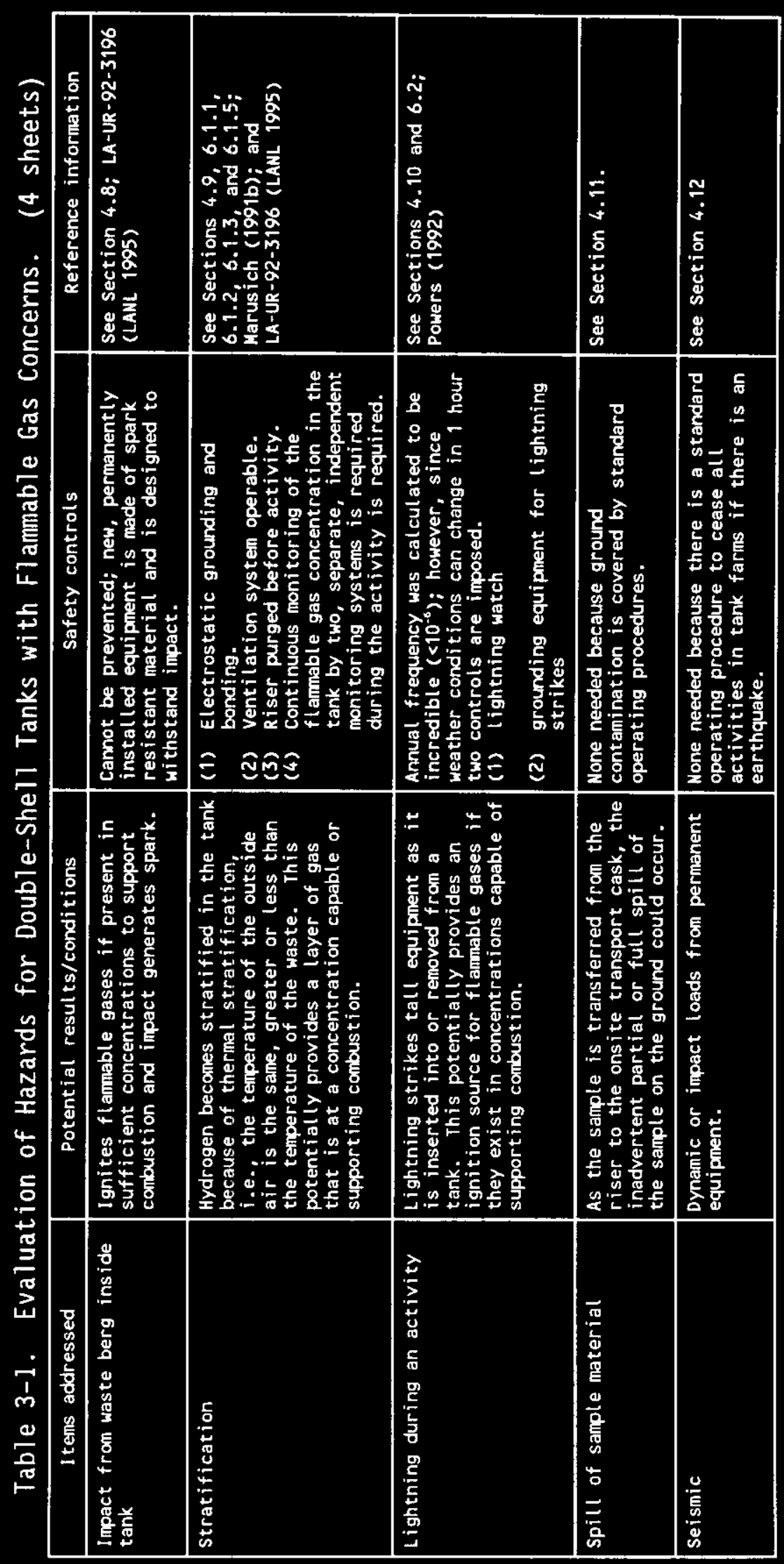


WHC-SD-WM-SARR-002 REV 1

This page intentionally left blank. 


\subsection{HAZARD ANALYSIS}

Potential hazards, equipment failures and ignition sources associated with activities in the double-shell flammable gas tanks are identified in Table 3-1. Table 3-1 also 1 ists the potential accidents, failure consequences, necessary safety controls, and the existing supporting analysis. An evaluation of activities associated with tanks having a flammable gas concern is covered in the following sections.

\subsection{ELECTROSTATIC SPARKS}

Earlier analysis (Marusich et al. 1991) showed that electrostatic grounding and bonding reduced the possibility of ignition sources in the tank.

Grounding and bonding procedures, as described in the appropriate National Fire Protection Association code sections for electrostatic bonding requirements in classified environments, prevents the discharge of electrostatic sparks. Therefore, if these procedures are followed, ignition of flammable gases by electrostatic sparks is considered to be an incredible event.

For example, the Tygon", or tygon-equivalent, tube is wire wrapped and bonded and grounded during sampling with the hand-held combustible gas meter. The question of electric sparks relating to existing equipment has been reviewed (Scaief 1994, Scaief 1995). Certain equipment has been determined to represent spark sources and has been deenergized or removed or will be removed. Some of the other equipment has been analyzed to show it can safely operate in flammable gas atmospheres. However, electrostatic sparks can never be totally eliminated or discounted. Therefore, a deflagration may occur and consequences are calculated in Section 5.3.

\subsection{MECHANICAL SPARKS OR FRICTIONAL HEATING}

A mechanical spark potentially could be created by dropping the equipment onto the riser or by swinging equipment in the riser while it is being installed or removed. The likelihood of dropping a crane load was judged by Farley (1992) to be $2.7 \times 10^{-5}$ per lift (see discussion in Section 4.7 ). Sparks produced by swinging are minimized by requiring equipment to be made out of spark-resistant material and by requiring installation to proceed slowly and deliberately (see Sections 6.2.2, 6.2.3, 6.2.4, and 6.2.6).

Calculations in Sontag (1991) show that $2.55 \times 10^{6}$ joules $\left(1.88 \times 10^{6} \mathrm{ft}-1 \mathrm{~b}\right)$ of frictional energy would be required to heat the edge of the riser to $800{ }^{\circ} \mathrm{C}\left(1472{ }^{\circ} \mathrm{F}\right)$, the autoignition temperature of a hydrogen-air mixture because of small heated spheres or bars. Because the contact area is small, the velocity of the object must be very fast to obtain this much frictional energy.

\footnotetext{
"Tygon is a trademark of Norton Company.
} 
Laboratory testing was done to qualify the auger (Griffin 1991). The temperature of the auger bit was measured during testing that was more severe than the field conditions. This testing indicated that there would be no possibility of an ignition caused by frictional heating during auger sampling because the temperature increase was only $8^{\circ} \mathrm{C}\left(15^{\circ} \mathrm{F}\right)$.

During push-mode sampling, localized heating of the waste may be a result of the friction of pushing the sampler through the waste. Extensive tests were run to determine the effect of frictional heating on the drill face surface and the waste simulant. The testing was conducted in three simulants: a sludge, a soft salt cake, and a hard salt cake. The results (Milliken 1993) indicated that there is no temperature increase from push-mode sampling the sludge simulant, there is a $6-^{\circ} \mathrm{C}\left(11-^{\circ} \mathrm{F}\right)$ temperature increase in the soft salt cake simulant, and there is a $22-^{\circ} \mathrm{C}\left(40-{ }^{\circ} \mathrm{F}\right)$ temperature increase in the hard salt cake. These temperature increases correspond to the maximum temperature increases seen during sampling of simulants. They are considered upper bounds because the sampling was done at penetration rates that are higher than those allowed in the field. Thus, these tests indicate that push-mode sampling of the single-shell flammable gas tanks would be expected to generate 1 ittle or no frictional heating. The possibility of an ignition caused by frictional heating during push-mode core sampling is an incredible event.

Activities will not occur in the tank if the measured flammable gas concentration is at or above 25 percent of the lower flammability limit (see Section 6.1.3 and Appendix B). However, the controls for insertion speed and critical lifts are administrative controls. Therefore, a mechanical spark is credible and consequences from a deflagration are calculated in Section 5.3 .

\subsection{EQUIPNENT FAILURE}

Each system described in the following subsections could fail or be improperly installed and generate ignition sources. Therefore, consequences from a deflagration are calculated in Section 5.3.

\subsubsection{Failure of the Standard Hydrogen Monitoring System}

Earlier analysis of a similar temporary gas monitoring system identified two hazards (Deere 1991). These hazards were the release of radioactive material and the potential ignition of flammable gases in the sample 1 ines. Deere (1991) calculated that the consequence of a release of radioactive material from the sample lines was negligible (i.e., much less than dose consequences caused by normal background radiation levels). In addition, the frequency calculated for ignition was found to be incredible $\left(<10^{-6}\right)$ (Deere 1991); therefore, the ignition of flammable gases in the sample line needs no further consideration.

Failure of the system to perform its intended function caused by failure of one of the system components also must be considered. One of the controls (see Section 6.1.3) for performing activities in the double-shell flammable gas tanks is to continuously monitor the concentration of flammable gases in the vapor space of the tank with two separate, independent monitors during any activity. For example, if monitoring is being done with as standard hydrogen 
monitoring system and a hand-held combustible-gas meter and if the standard hydrogen monitoring system has failed, the control can be satisfied by using a second hand-held combustible-gas meter positioned so that the sample is being drawn from the tank at approximately the same location as the standard hydrogen monitoring system would draw its sample. The standard hydrogen monitoring system would be repaired or replaced.

\subsubsection{Failure of Photographic Equipment}

The photographic equipment to be used in the flammable gas tanks must meet the requirements of National Fire Protection Association, National Electric Code, Article 501 for use in Class I, Division 2, Group B (flammable hydrogen environment), for flammable hydrogen environments, therefore an ignition in the vapor space from camera operations is judged to be an incredible event. In addition, electrical power will be off during installation and removal of this equipment.

\subsubsection{Failure of the Instrument Tree}

The failure of individual thermocouples or resistance temperature detectors in the instrument tree would not create a problem. Currently the double-she11 tank Interim Operational Safety Requirements are met as long as at least one thermocouple or resistance temperature detector is functioning below the waste surface. If thermocouples or resistance temperature detectors fail, the instrument tree would likely be replaced. A failed instrument tree is not a hazard.

\subsubsection{Failure of the Auger Sampler}

The auger can fail to perform functionally; i.e., the auger does not deliver a sample because the waste surface is similar to a liquid and no sample stays attached to the auger flights. If no sample is retrieved, the course of action would be to resample using the auger sampler. If the

additional tries also failed, the guide tube assembly and auger assembly would be removed and an alternative method of sampling may be chosen (such as waste grab sampling as described in Section 2.7).

\subsubsection{Failure of the Push-Mode Core System}

The drill string in the push-mode core system could buckle and fail at $16 \mathrm{kN}(3,600 \mathrm{lbf})$ if it is not constrained by waste (Milliken 1993). However, actual damage to the drill string is not a concern for this assessment because it does not result in a propagating exothermic waste surface reaction, an ignition of flammable concentrations of gases, a toxic gas release, or a spill of radioactive material. In addition, the tank confinement can be restored by using a split spool piece to seal around the drill string until the bent drill string can be removed from the tank.

Flammable gas buildup has been observed in the drill string; however, drill string flammable gas measurements have been required only recently. The 
occurrence of flammable gas above the lower flammability 1 imit has happened three times in the recent past. Additionally, there are components such as the remote latching unit that are not rated for flammable gas environments. However, the buildup of gas has occurred only while the drill string was inactive. While sampling is ongoing, purge gas or hydrostatic fluid floor will keep flammable gases from building up. It is only when the drill string is inactive and a sampler is not installed in the drill string (0-ring seals keep gas from entering the drill string) that this is a problem. Therefore, to prevent an accident if the drill string has been inactive, a measurement of the concentration in the drill string will be made. If the reading is above 25 percent of the lower flammable limit (as defined in Appendix B), the drill string will be vented. Purge intervals are defined in Appendix $C$. Purging will continue until two consecutive measurements are less than 25 percent of the lower flammability limit (as defined in Appendix B). Work then can cont inue.

\subsection{GAS RELEASE EVENT}

To adequately address the issue of why the same activities done in tank 241-SY-101 can safely be done in other double-shell tanks with flammable gas concerns, an evaluation of the comparative risk must be performed. Section 1.3 describes the retention and release mechanism for double-shell tanks.

In the unlikely event that flammable gases were present in concentrations to support ignition and a spark source was introduced, the consequences would be similar to the consequences calculated in LA-UR-92-3196, A Safety Assessment for Proposed Pump Operation to Mitigate Episodic Gas Releases in Tank 241-SY-101 (LANL 1995). These calculations can be substantiated by comparing them with the information presented in Table 4-1. Table 4-1 presents information on the operating level, the vapor space volume, the maximum historical level drop, a calculated volume of gas corresponding to the prompt gas release in tank 241-SY-101, the adiabatic burn pressure, and the unit dose consequence for each tank. The unit dose consequences have been based on the latest sample results from each of the double-shell flammable gas watch list tanks (Van Vleet 1993a). These unit dose consequences are reported in the Hanford Site Tank Farm Facilities Interim Safety Basis, Volume 1 \& Volume 2 (Leach and Stahl 1993).

It should be noted that the gas release amounts in Table 4-1 are considered bounding. The Rayleigh-Taylor model assumes that the trapped gas is held in place until it reaches the point where it is buoyant enough to cause an instability. The release of gas is a complete whole tank rollover. Current calculations of gas release volumes are based on the observed level drops and pressure increases for tank 241-SY-103 are approximately three to five times less than those in Table 4-1, which are calculated using the Rayleigh-Taylor methodology. The existing tank data indicate that complete tank rollovers do not occur in these tanks (103-SY, 101-AW, 103-AN, 104-AN, and 105-N); only partial rollovers or local releases occur. For this analysis, the release of the gas is considered to occur instantaneously. The majority of the gas in tank 241-SY-101 was released within the first 2 minutes 
Table 4-1. Comparison of Double-Shell Tank Parameters.

\begin{tabular}{|c|c|c|c|c|c|c|c|}
\hline Tank & $\begin{array}{l}\text { Operating } \\
\text { level } \\
\text { (m) }\end{array}$ & $\begin{array}{c}\text { Vapor } \\
\text { space } \\
\text { volume } \\
\left(\mathrm{m}^{3}\right)\end{array}$ & $\begin{array}{l}\text { Maximum } \\
\text { historical } \\
\text { level drop } \\
\text { (cm) }\end{array}$ & $\begin{array}{l}\text { Prompt } \\
\text { gas } \\
\text { relegase } \\
\left(m^{3}\right)^{a}\end{array}$ & $\begin{array}{c}\text { Adiabat ic } \\
\text { burn } \\
\text { pressure } \\
\text { (MPa) }^{\text {b }}\end{array}$ & $\begin{array}{c}\text { Total } \\
\text { organic } \\
\text { carbon } \\
(\mathrm{g} / \mathrm{L})\end{array}$ & $\begin{array}{l}\text { Unit liter } \\
\text { dose } \\
\text { consequences } \\
(\mathrm{Sv} / \mathrm{L})^{\mathrm{c}}\end{array}$ \\
\hline 101-SY & 10.41 & 1,063 & 33.53 & 233 & 0.658 & 26 & $1.9 \times 10^{3}$ \\
\hline 101-AW & 10.54 & 1,011 & 4.83 & 171 & 0.581 & 4.4 & $1.5 \times 10^{3}$ \\
\hline 105-AN & 10.45 & 1,047 & 8.64 & 190 & 0.553 & 4.1 & $9.3 \times 10^{1}$ \\
\hline 104-AN & 9.87 & 1,285 & 14.73 & 171 & 0.470 & 4.3 & $5.0 \times 10^{4}$ \\
\hline 103-AN & 8.81 & 1,722 & 7.62 & 166 & 0.380 & 4.9 & $2.4 \times 10^{2}$ \\
\hline 103-SY & 6.96 & 2,481 & 5.84 & 102 & 0.231 & 11 & $5.5 \times 10^{2}$ \\
\hline $\begin{array}{c}\text { Double-shell tank } \\
\text { composite }\end{array}$ & & & & & & & $5.3 \times 10^{5}$ \\
\hline $\begin{array}{l}\text { Aging waste } \\
\text { solids composite }\end{array}$ & & & & & & & $1.8 \times 10^{6}$ \\
\hline A11 solids & & & & & & & $1.9 \times 10^{6}$ \\
\hline
\end{tabular}

This is $70 \%$ of the total anount of retained gas calculated using the Rayleigh-Taylor instability model.
$b_{\text {This }}$ is calculated assuming that $\mathrm{H}_{2} / \mathrm{H}_{2} 0=1.18, \mathrm{H}_{2} / \mathrm{HH}_{3}=2.5$, and $\mathrm{H}_{2} / \mathrm{CH}_{2}=20$ and assumes that there are no inert gases such as water vapor or nitrogen in the reieased gases? Using these assumptions, the coliposition of the released gas is (in volx): $\mathrm{H}_{2}=43.5$, $\mathrm{N}_{2} \mathrm{O}=36.9, \mathrm{NH}_{3}=17.4$, and $\mathrm{CH}_{4}=2.2$.

Leach alnd stahi (1993). NorE: These numbers have corrected fgom those reported in Leach and Stahl. That is, the numbers from The numbers reported here are the maximm unit liter dose to be used to calculate both onsite and offsite consequences from a hypothetical accident.

hypothey is the conitted effective dose equivalent per liter inholed (Savino 1905) for the double-shell tank solids, or the agine waste solids, or all solids. See Chapter 5 of this docunent for more discussion. 
(LANL 1995). Monitoring data (hydrogen concentration and pressure) indicate that the releases in the other double-shell tanks appear to follow this same pattern. Surface-level drops appear to take much longer in these other tanks as compared to behavior in tank 241-SY-101. For example, tank 104-AN experiences the next largest level decreases in the double-shell flammable gas watch 1 ist tanks. The largest drop in tank $104-\mathrm{AN}$ was $14.73 \mathrm{~cm}$ (5.8 in.), with $9.14 \mathrm{~cm}$ (3.6 in.) occurring in the course of 1 day.

\subsection{TOXIC GAS RELEASE DURING ACTIVITY}

While tank confinement is breached (e.g., opening of the riser or sample port) there is a possibility for toxic gases (e.g., ammonia, organic vapors, and nitrous oxide) to be released. The personnel working near the open riser, open sample port, or any other opening in the tank and those personnel elsewhere in the tank farm, e.g., the upwind staging area, shall wear respiratory protection as determined by the field representative of Tank Waste Remediation System Industrial Hygiene. The level of protection for those personnel will be based on the field measurements and the requirements in the Tank Farm Health and Safety Plan (Carls 1995)".

In addition, while tank confinement is breached, monitoring for toxic gases will be conducted periodically. The gas monitoring shall be performed in accordance with standard work practices contained in Carls (1995). If a toxic gas release is detected during the work, the workers can be evacuated or other appropriate measures taken.

Toxic gas releases may occur during a gas release event. The amount of toxic gas released (e.g., ammonia) will be proportional to both the magnitude of the gas release and the time over which the release occurs. However, there is a short time delay between a gas release event and worker exposure. Also, the tank conditions shall be monitored for the entire time the activity is being performed. This monitoring will include, at a minimum, the tank waste level and the hydrogen concentration in the tank using two, separate, operable monitors (measured at a location in the tank vapor space [below the riser lip]). For example, a hand-held combustible-gas meter with a wire-wrapped, electrically-bonded Tygon or Tygon-equivalent tube and the standard hydrogen monitoring system and gas probe assembly could be used. An operator shall look for indications that a gas release event might occur, e.g., sudden decrease in level and/or an increase in the hydrogen concentration. These indications or precursors may enable the tank to be placed in a safe shutdown mode and/or the workers evacuated from the area.

The pH of the tank waste can cause differences in the production rates of toxic chemicals. For example, hydrogen cyanide should not exist in very basic conditions. However, if the $\mathrm{pH}$ is lower (near a $\mathrm{pH} \mathrm{9),} \mathrm{the} \mathrm{production} \mathrm{of}$ hydrogen cyanide is possible. Also, addition of water or caustic to tanks with low $\mathrm{pH}$ values will cause ammonia to be produced. Thus, the monitoring while tank confinement is broken should take into consideration the types of toxic gases that could be formed.

"NOTE: It is procedurally required for nuclear safety, fire protection, and industrial hygiene organizations to review and approve safety analyses. 
Toxic gases also may be produced during a deflagration. The types of gases produced would be highly sensitive to the several parameters. Some of these are the initial reactants, the temperature of the deflagration, the duration of the deflagration, any catalysts present, and any secondary reactions that might take place. Occupational workers wear personal protective equipment as required by the Tank Farm Health and Safety Plan (Carls 1995). Onsite individuals are protected through emergency preparedness and offsite individuals are protected by distance (dilution of concentration through dispersion). No consequences will be calculated in Chapter 5.0.

\subsection{DAHAGE TO TANK}

A potential safety issue is the contamination or dropping of the gauge plug, a replacement level-indicating device, or other equipment that is manually brought into the tank farm. The "T" handle would prevent the gauge plug from falling into the tank, if it were accidently dropped. Similarly, the replacement level-indicating device would be physically too large to fall into the tank. If the equipment were dropped onto the riser flange, damage to the riser flange would be minimal, and the riser could still be sealed with a thick "donut-type" gasket or a plastic glove bag until it could be repaired. The gauge plug may become contaminated by scraping a contaminated riser interior during insertion and/or removal. During removal, the gauge plug will be examined for radiation contamination by a health physics technician and, if necessary, wiped clean or disposed of in accordance with the Tank Farm Health and Safety Plan, (Carls 1995) and the Hanford Site Radiation Control Manual (HSRCM 1992). By using the guidelines in these manuals, it is expected that the dose rate to workers performing contamination control will be very low.

As discussed in WHC-SD-WM-SAD-014 (Farley 1992) the likelihood of typical cranes dropping a load is $2.7 \times 10^{-5}$ per $1 \mathrm{ift}$. The 1 ikel ihood assigned for a crane dropping a multifunction instrument tree is based on statistics from NUREG (1980). This report analyzed U.S. Navy crane lifts in the period from February 1974 to October 1977 for a variety of crane types. During the analys is period, there were on average $8.75 \times 10^{+5}$ crane lifts/year. Based on the number of reported load drop accidents reported in this time period, the likelihood of a dropped load accident was determined to have a mean value of $2.7 \times 10^{-5}$ per $1 \mathrm{ift}$, which falls in the "extremely unlikely" category as defined in Section 4.1. Failure modes were analyzed to determine if Navy procedures could be improved to meet nuclear power plant standards in NUREG (1980). NUREG (1980) determined that the potential accident rate could be further reduced by more thorough operator training and operating procedures.

Riser damage would occur if heavy equipment were dropped onto the riser. If heavy equipment were dropped, the riser could be damaged to the extent that tank confinement could not be maintained at that location during a gas release event (NOTE: Only gas release events in tanks 241-SY-101 have caused tank pressure to become positive). However, the riser could be temporarily sealed by a plastic glove bag or a thick flexible gasket, and the riser repaired at a later time. Confinement would be maintained during normal conditions by 
maintaining negative pressure in the tank. This would cause air inflow rather than tank vapor outflow. Therefore, there are no radiological or hazardous consequences because of riser damage.

Tall equipment has the potential of dropping into the tank and damage the tank liner. However, preventative measures have been adopted to mitigate this aspect of equipment installation or removal. During manual installation, at least one lifting bar shall be in place for both the auger guide tube assembly and the auger sampling equipment. During crane installation of the guide tube and auger sampling equipment, the lifts are considered critical lifts and precautions such as impact limiters should be taken. The guidelines in the Hanford Site Hoisting and Rigging Manual (DOE-RL 1992) shall be followed. This will minimize the possibility dropping tall equipment into the tank. This also minimizes frictional heating, mechanical sparking, and impact heating from dropped objects.

The core drill truck has redundant features to prevent the possibility of pushing through the liner of the tank (Milliken 1993). They are as follow: (1) the drill string is equipped with a hydraulic safety interlock that disables the hydraulic system if a resistance greater than that resulting from sampling occurs, (2) conservative calculations show that the maximum downward force the core drill truck can exert cannot penetrate the liner of the tank even if the hydraulic interlock were to fail, and (3) strict administrative and quality assurance controls on the calculation of the drill string length are relative to the tank depth.

The multifunction instrument tree has a flange welded on the top to allow it to be bolted to the riser. If the multifunction instrument tree was dropped, the flange would stop it from penetrating the tank 1 iner.

Consequences for damage to the tank are presented in Section 5.2. Consequences from a deflagration are presorted in Section 5.3.

\subsection{INPACT FROH WASTE BERGS}

Waste bergs were first identified in tank 241-SY-101. They were observed through the closed-circuit television camera during gas release events. Some of the original equipment in tank 241-SY-101, e.g., the air 1 ances and the thermocouple tree, had been impacted by waste bergs during past gas release events. This impact was evidenced by bends in the equipment. This bent equipment has since been removed from the tank. It is assumed that waste bergs exist in the five other double-shell flammable gas watch list tanks.

As mentioned above, waste bergs are mobile only during gas release events. The gas release events occurring in tank 241-SY-101 release the largest gas volume (see Table 2) in the shortest period of time. Thus, the velocity of the waste bergs in tank 241-SY-101 is thought to bound the other tanks. The movement or even the presence of waste bergs in the other doubleshell flammable gas watch list tanks will not be known until the in-tank closed-circuit television camera is installed.

The waste bergs also only affect equipment that penetrates the waste. of the equipment described in this document, only the multifunction instrument 
tree penetrates into the waste and is a permanent fixture. The multifunction instrument tree has been tested in the laboratory to determine the number of bends it takes to fail. A hairline fracture at the bend was noticed after the multifunction instrument tree had been bent $45^{\circ}$ in one direction, bent $90^{\circ}$ in the direction opposite of the first, and then bent $90^{\circ}$ in the same direction it was bent the first time. The bend in the multifunction instrument tree would be located immediately below the riser opening where it penetrates the vapor space.

If the multifunction instrument tree was bent during a gas release event, the following steps would be taken. A visual survey of the multifunction instrument tree with the closed-circuit television camera would be conducted. The multifunction instrument tree would be functional tested, $i . e$. , the continuity of the thermocouples would be checked. A management decision would be made to determine if the multifunction instrument tree would still be operated or if it needed to be removed and replaced.

In tank 241-SY-101, the possibility of equipment impacting on other equipment exists during gas release events. For example, one of the new camera systems in tank 241-SY-101 will go into the multiport riser adaptor. The multiport riser adaptor is designed to fit onto the $106.7-\mathrm{cm}(42-\mathrm{in}$. riser. It creates three risers of varying size. The' new camera system is designed to fit into one of these. Although unlikely, if other installed equipment in the multiport riser adapter strikes the new camera system because of a waste berg impact, steps similar to those described in the paragraph above would be taken. An operational test will be conducted on the purge gas system. If the purge system is still functional, then the camera is still safe to operate within the classified region of the tank. If the purge gas system fails, the camera will need to be removed for repair or replacement.

Movement of a waste berg happens during a gas release event. The movement might produce an ignition source (impact with equipment or the walls of the tank). The consequences from a deflagration are reported in Section 5.3 .

\subsection{STRATIFICATION}

Stratification was addressed in Marusich (1991a, Appendices D.1 and D.2) where it was shown that hydrogen does not stratify in a passively ventilated tank (used to represent a tank that has lost active ventilation). However, Los Alamos National Laboratory, the group that wrote the safety evaluation report for the activity (push-mode sampling) thought that stratification could occur. As a result, a temperature-difference-based control was imposed. Further studies at Los Alamos National Laboratory (LANL 1995) were conducted and concluded that stratification would not occur in actively ventilated tanks, thus eliminating the temperature-difference-based control for these tanks. Furthermore, Wood (1994) has stated that the vapor spaces of these tanks are well mixed, or will become well mixed in a short period of time, because of the thermal differences between the waste and the ambient air temperatures. Wood $(1994)$ has calculated ventilation rates of about $2.1 \times 10^{-2} \mathrm{~m}^{3} / \mathrm{s}\left(45 \mathrm{ft}^{3} / \mathrm{min}\right)$ in the single-shell tanks be analyzed. Modeling of a double-shell waste tank with a low ventilation rate during a gas release has been completed (Antoniak and Recknagle 1995). This modeling looked at 
small releases of gas with volumes ranging from 11.3 to $28.3 \mathrm{~m}^{3}$ (400 to $1,000 \mathrm{ft}^{3}$ ) with release durations ranging from 1 minute to 2 hours with a ventilation rate of $2.4 \times 10^{-2} \mathrm{~m}^{3} / \mathrm{s}\left(50 \mathrm{ft}^{3} / \mathrm{min}\right)$ at two temperatures, $48.9{ }^{\circ} \mathrm{C}$ $\left(120^{\circ} \mathrm{F}\right)$ and $-6.7^{\circ} \mathrm{C}\left(20^{\circ} \mathrm{F}\right)$. These analyses showed that a significant concentration ( 8 percent by volume) could accumulate at the apex of the tank and this would be reduced to 3 percent by volume within 2 hours. These combined results will apply to the actively ventilated double-shell tanks with flammable gas concerns.

To ascertain whether stratification is a valid concern for an activity, the hydrogen concentration in the tank (measured at a location in the tank vapor space [below the riser lip]) using two separate, operable monitors (see Section 6.1.3) will be monitored continuously during an activity. In addition, when a riser flange is first removed during an activity, a purge period (see Appendix C) will be observed to allow any trapped gases to escape.

Other flammable gases are generated and have been measured in tanks. For example, in tank 241-SY-101, ammonia and methane have been measured. The background concentration for ammonia has been measured at approximately $40 \mathrm{ppm}$. The lower flammable limit for ammonia is 15 volume percent $(150,000 \mathrm{ppm})$ in air. Currently methane data have only been measured in the Window I gas release event on tank 241-SY-101. The peak-measured value was approximately $370 \mathrm{ppm}$. The lower flammable limit for methane is 5 volume percent $(50,000 \mathrm{ppm})^{*}$ in air. These gases also will be measured for when using the hand-held combustible gas meter. The presence of ammonia and methane also was taken into account when developing the conservative slurry gas composition as discussed in Appendix B.

The potential for stratification only exists after a gas release event has occurred. However, because of known spark sources in the tank and because an activity may be occurring, the consequences of a deflagration are presented in Section 5.3 .

\subsection{LIGHTNING}

Lightning during an activity. During installation or removal of tall equipment (i.e., $3 \mathrm{~m}[10 \mathrm{ft}]$ ), a lightning strike could occur. This is an unlikely event given the low thunderstorm/lightning frequency in the Hanford area. In fact, using the information on local lightning strikes obtained from the U.S. Geological Survey, Cowley (1994) has estimated an annual frequency of $4.5 \times 10^{-4} / \mathrm{yr}$ per tank.

* Other values for the lower flammability limits in air and nitrous oxide are discussed in Appendix $B$ of this document. 
For any activity, this would lead to a frequency of

$$
\left(\frac{1}{8,766 \frac{\text { hours }}{\text { year }}}\right)\left(4.5 \times 10^{-4} \frac{\text { strikes }}{\text { year }}\right)=5.133 \times 10^{-8} \frac{\text { strikes }}{\operatorname{tank}} \text { per hour of activity. }
$$

Although not credited in this analysis, during installation of tall equipment into single-shell flammable gas tanks, the crane and the tall equipment will be electrically bonded to the tank to protect against 1 ightning strikes, as indicated in Weadon (1992a). A control for bonding and grounding for lightning is included in Chapter 6.0.

Also not credited in this analysis is the standard practice while installing new or modified large equipment that prohibits working in the tank farm unless a storm warning report from the Pacific Northwest Laboratory states that a storm is not occurring within a $80.5-\mathrm{km}$ (50-mile) radius of the Hanford Site, and is not likely to occur within some specified time period. This would further reduce the risk from a storm. On days having higher thunderstorm potential (May through August), the prediction of no 1 ightning within a $80.5-\mathrm{km}$ (50-mile) radius may be good for only 1 hour. During the winter months, predictions may be good for several days. A control for a weather watch is included in Chapter 6.0.

The chance of lightning causing an explosion would also have to consider the likelihood that a tank contained a flammable gas mixture concurrent with the lightning strike and the installation activity. The likelihood thus would decrease even more.

\subsection{SPILL OF SANPLE MATERIAL}

For either the auger sampling system or the push-mode sampling system, the inadvertent partial or full spill of the sample on the ground could occur while the sample is being transferred from the riser to the onsite transport cask. The volume of waste in the sample from the auger sampling system is $475 \mathrm{~cm}^{3}(745 \mathrm{~g})$. The volume of waste in the sample from the push-mode sampling system is $310 \mathrm{~cm}^{3}(500 \mathrm{~g})$. Two events (both human failures) must occur for a spill to happen and if a probability of $10^{-2}$ is assigned to each of these events, a total of $10^{-4}$ per sampler results. The fullest doubleshell tank is 241-AN-104 with 4,016,300 L $(1,061,000$ gal) of waste. This corresponds to $10.4 \mathrm{~m}$ (410.2 in.). To core sample this tank, a total of 21 to 22 samples would be used to obtain a full core sample. If it is assumed that there is a maximum of 20 samplers per core sampling, the frequency is $2.2 \times 10^{-3}$. Therefore, consequences from this accident will be analyzed in Chapter 5.0. 


\subsection{SEISHIC}

The dynamic or impact loads on permanent equipment in the single-shell flammable gas tanks caused by seismic events will be evaluated and documented before the equipment is installed in the tank.

The annual frequency of a concurrent earthquake causing a gas release event while an activity is taking place in a single-shell flammable gas tank is given as

$$
\left(\frac{1}{8,766 \frac{\text { hours }}{\text { year }}}\right)\left(1 \times 10^{-4} \frac{0.2 \mathrm{~g} \text { earthquakes }}{\text { year }}\right)=1.1 \times 10^{-8} \frac{0.2 \mathrm{~g} \text { earthquakes }}{\text { hour }}
$$




\subsection{CONSEQUENCE OF ACCIDENTS}

Consequences will be calculated for two receptor locations: maximum onsite and offsite individuals. The definitions of these receptor locations (WHC-CM-4-46) are:

"The hypothetical onsite receptor located at the distance and direction from the point of release at which the maximum dose occurs. This distance shall be at least $100 \mathrm{~m}$. Line management may, with Health and Safety Assurance concurrence, redefine the maximum onsite individual for a specific facility to be located at the facility boundary, in the direction of the maximum dose."

For this analysis, the onsite receptor evaluation location is $100 \mathrm{~m}$.

"The hypothetical receptor at or beyond the site boundary location, with the maximum atmospheric dilution factor, for which offsite consequences are calculated."

For this analysis, the offsite receptor evaluation location is $11.1 \mathrm{~km}$ to the west of the 200 Areas. The maximum atmosphere dilution factor is the largest numerical value which directly corresponds to the maximum dose consequence. locations.

The following sections provide the consequences at these two receptor

\subsection{CONSEQUENCES FOR DROP OF SAMPLE MATERIAL}

The consequences for dropping a sample retrieved by auger sampling or push-mode core sampling are similar. Milliken (1993) calculated that the universal sampler (used with the core drill truck) could contain a volume of $310 \mathrm{~cm}^{3}(500 \mathrm{~g})$ (assuming a density of $1.6 \mathrm{~g} / \mathrm{cm}^{3}$ for the waste material). It was further assumed that it was a dry, respirable powder with a resuspension value of 0.1 percent. This leads to a release amount of $0.31 \mathrm{~cm}^{3}$ $\left(3.1 \times 10^{-4} \mathrm{~L}\right)$. Similar calculations for the auger sampler yield a volume of $465 \mathrm{~cm}^{3}(745 \mathrm{~g})$. Van Vleet (1991) indicates that after the auger with the floating sleeve covering the sample is in the retrieval cask, no more than half of this material could leave the sampler. Again the same assumption that the material is a dry, respirable powder with a resuspension of 0.1 percent yields a release amount of $0.23 \mathrm{~cm}^{3}\left(2.3 \times 10^{-4} \mathrm{~L}\right)$. The sample spilled from the universal sampler is larger and thus has bounding consequences.

Radionuclide composite inventories were developed by using characterization data for the waste tanks (Savino 1995). Radionuclide composites were generated for 12 tank groupings (for example, double-shell tank 1 iquids and double-shell tank solids). Details on the composites can be 
found in Savino (1995). For this analysis, the composite selected are doubleshell tank solids, aging waste facility solids, and all solids. The unit liter dose for this composite are shown in Table 4-1. The dose consequences in sieverts can be calculated using

$$
D=Q \times \frac{X}{Q^{\prime}} \times R \times U L D
$$

where

$$
\begin{array}{ll}
Q & =\text { liters respirable tank waste released } \\
\chi / Q^{\prime} & =\text { integrated atmospheric dispersion coefficient } \\
R & =\text { breathing rate } \\
U L D & =\text { committed effective dose equivalent per unit liter inhaled. }
\end{array}
$$

The atmospheric dispersion coefficients are $3.44 \times 10^{-2} \mathrm{~s} / \mathrm{m}^{3}$ for the onsite receptor and $1.88 \times 10^{-5} \mathrm{~s} / \mathrm{m}^{3}$ for the offsite receptor. The breathing rate is $3.3 \times 10^{-4} \mathrm{~m}^{3} / \mathrm{s}$ which is for a person doing 1 ight activity. The radiological consequences from a drop of sample material are presented in Table 5-1.

Toxic chemical source term concentrations also were developed using tank characterization data (Van Keuren 1995). Toxic composites were generated for eight tank groupings (for example, double-shell tank 1 iquids and double-shell tank solids). The toxic composite for double-shell tank contains aging waste tank data too. For further details on the composites see Van Keuran (1995). For this analysis, the double-shell tank solids puff release and all solids puff release sum-of-fraction of the risk guidelines for a unit liter dose were used. This is $2.9 \times 10^{2}$ per liter for the onsite receptor and $2.7 \times 10^{-2}$ for the offsite receptor. The dose consequences can be calculated using the following.

$$
\text { Fraction of Risk Guidelines }=0 \times \text { SOF }
$$

where

$$
\begin{aligned}
Q & =1 \text { iters of respirable tank waste released } \\
\text { SOF } & =\text { sum-of-fractions per unit liter inhaled. }
\end{aligned}
$$

The toxicological consequences from a drop of sample material are presented in Table 5-1. 
Table 5-1. Dose Consequences for Spill of Sample Material.

\begin{tabular}{|l|c|c|c|c|}
\hline \multirow{2}{*}{$\begin{array}{c}\text { Composite } \\
\text { waste type }\end{array}$} & \multicolumn{2}{c|}{$\begin{array}{c}\text { Committed effective } \\
\text { equivalent dose (mSv) }\end{array}$} & \multicolumn{2}{c|}{$\begin{array}{c}\text { Toxic chemicals } \\
\text { sum-of-fractions }\end{array}$} \\
\cline { 2 - 5 } & Onsite & offsite & Onsite & Offsite \\
\hline $\begin{array}{l}\text { Double-she11 } \\
\text { solids }\end{array}$ & 1.9 & $1.0 \times 10-3$ & 0.22 & $7.1 \times 10^{-6}$ \\
\hline $\begin{array}{l}\text { Aging waste } \\
\text { solids }\end{array}$ & 6.3 & $3.5 \times 10-3$ & 0.22 & $7.1 \times 10^{-6}$ \\
\hline All solids & 6.7 & $3.7 \times 10-3$ & 2.0 & $2.0 \times 10^{-5}$ \\
\hline
\end{tabular}

WOTE: The toxic composite for double-shell tanks contains aging waste tank data too. The radiological composites, are separate for double-shell and aging waste tanks.

\subsection{COMSEQUENCES FRON DAMAgE TO THE TANK}

One postulated accident scenario would result in an adverse impact to the environment: dropping the multifunction instrument tree through the bottom of the tank. An analysis of the effect of tank leakage on the water table is discussed in Smith (1986) and covers a hypothetical $3.79 \times 105 \mathrm{~L}$ $\left(1.0 \times 10^{5} \mathrm{gal}\right)$ leak from a double-shell, aging waste tank. The reference document (Smith 1986) indicates that the analyzed scenario for the doubleshe11, aging waste tank bounds the consequences for a single-shell tank. The analysis concluded that concentrations of radionuclides arriving at the water table would be below federal guidelines for drinking water. It was further postulated that two $1.14 \times 10^{5} \mathrm{~L}\left(3.0 \times 10^{4}\right.$ gal) leaks of fluid waste from adjacent single-shell tanks would have a vertical penetration of on $1 \mathrm{y} 27.4 \mathrm{~m}$ $(90 \mathrm{ft})$, compared to $36.6 \mathrm{~m}(120 \mathrm{ft})$ for the double-shell tank leak scenario. The water table is approximately $61 \mathrm{~m}(200 \mathrm{ft})$ below the 200 West Area and $91 \mathrm{~m}(300 \mathrm{ft})$ below the 200 East Area.

Other scenarios for waste tank leakage are covered in the draft environmental impact statement, EIS-0113, Vol. 3 (DOE 1986). The environmental impact statement states that the most applicable study for potential offsite doses from single-shell tank leakage was done by Murthy et al. (1983), with the following conclusions:

"The controlling radionuclides that contribute to these doses are technetium-99 and iodine-129, both of which are available only in small quantities. Other radionuclides of potential concern (cesium-137, strontium-90, neptunium-237) were also analyzed. Hydrological modeling indicated that although cesium-137 and strontium-90 are available in greater quantities, they will never reach the accessible environment before decay due to their relatively short half-lives and soil sorption. The trace amounts of neptunium-237 available have a very long half- 
life, but are not expected to reach the ground water due primarily to the lack of sufficient driving liquids and soil sorption."

Any postulated waste leak, on reaching the soil, will be driven downward by rainfall and runoff from the tank dome. This moisture recharge is concentrated around the tank perimeter because of the "umbrella effect" of the tank structure. Travel time to the aquifer is calculated to be about 60 years, provided the amount leaked is small (up to tens of cubic meters) compared to the rate of recharge. Even small leaks are expected to find their way to the groundwater. The transport model used to simulate the leak is conservative in that the travel time estimates are minimal for representative conditions and the relative concentrations in the groundwater are maximal.

Local concentrations of key waste constituents in the ground water resulting from the most likely leak scenario are predicted to be greater than allowed by drinking water standards. These doses reflect the inherent conservatism in the transport model. The actual dose received will depend on the water well location, the extent of mixing in the aquifer, and any lateral

spreading that occurs. Significant dilution is possible between the source of the leak and the dose receptor, such that the resulting dose may approximate or even be less than allowed by drinking water standards. This study assumed a well located $25 \mathrm{~m}$ from the tank. However, all these consequences are long-term and there are no short-term consequences to the onsite or offsite receptor.

Considering the extremely low likelihood of this event, it is concluded that a leak caused by a tall piece of equipment (i.e., an instrument tree) penetrating a tank would pose no significant short-term risk to offsite or onsite workers, but might add to future cleanup efforts. Long-term risks are discussed in Smith (1986), Murthy et a1. (1983), and EIS-0113, Vol. 3

(DOE 1986) and Lowe (1993). Work has been ongoing in the areas of recharge and transport of the radionuclides, but the basic conclusion that there is no short-term risk still is valid.

\subsection{CONSEqUENCES FRON IGNITION OF A GAS RELEASE}

The consequences from an ignition of a gas release event are presented in Table 5-2. These consequences are derived from the detailed calculations presented in A Safety Assessment for Proposed Pump Mixing Operations to Mitigate Episodic Gas Releases in Tank 241-SY-101: Hanford Site, Richland, Washington (LANL 1995).

Double-she11 tanks respond well to pressure pulses because the domes of the double-shell tanks are lined with steel. Computer modeling has shown that the dome will undergo stress relief cracking at a riser weld in the transition region (where the tank walls meet the dome) only after the shell experiences an overpressure of $413.7 \mathrm{kPa}$ gauge $\left(60 \mathrm{lb} / \mathrm{in}^{2}\right.$ [gauge]). Prediction of pressure increases from postulated burns of gases from gas-release events in tank 241-SY-101 and other flammable gas watch list tanks indicates that the maximum pressure increase for a $245 \mathrm{~m}^{3}$ burn in tank 241-SY-101 would be about $413.7 \mathrm{kPa}$ gauge (60 lb/ $\mathrm{in}^{2}$ [gauge]) (LANL 1995, LANL 1994) and that the pressure increase for the other tanks studied would be below that. This is 
Table 5-2. Ignition Dose Consequences.

\begin{tabular}{|l|c|c|c|c|}
\hline \multirow{2}{*}{$\begin{array}{c}\text { Composite } \\
\text { waste type }\end{array}$} & \multicolumn{2}{|c|}{$\begin{array}{c}\text { Committed effective } \\
\text { equivalent dose (mSv) }\end{array}$} & \multicolumn{2}{|c|}{$\begin{array}{c}\text { Toxic chemicals } \\
\text { sum-of-fractions }\end{array}$} \\
\cline { 2 - 5 } & Onsite & offsite & Onsite & Offsite \\
\hline $\begin{array}{l}\text { Double-she11 } \\
\text { tank solids }\end{array}$ & 17,000 & 9.5 & 9,000 & 0.34 \\
\hline $\begin{array}{l}\text { Aging waste } \\
\text { solids }\end{array}$ & 59,000 & 32 & 9,000 & 0.34 \\
\hline All solids & 62,000 & 34 & 25,000 & 0.45 \\
\hline
\end{tabular}

radiological composites are separate for double-shell and aging waste tanks.

the largest gas release allowed during pump operation. Before mixer pump operation, tank 241-SY-101 had gas releases up to a volume of $297 \mathrm{~m}^{3}$. Burn of a release this size would lead to dome collapse (LANL 1995). Also, if the flammable gases from a gas-release event were added to an atmosphere that already had a high concentration of flammable gases because of inadequate ventilation, the ignition and burn of the mixture would produce pressures higher than $413.7 \mathrm{kPa}$ gauge $\left(60 \mathrm{lb} / \mathrm{in}^{2}\right.$ [gauge]) and would lead to dome collapse (WHC 1995).

For this case, it is assumed that ventilation has kept the headspace free of flammable gases before a gas-release event and that the volume of the releaşe is the maximum release allowed during mixer pump operation (i.e., $245 \mathrm{~m}^{3}$ ). This bounds the releases from the other $\mathrm{flammable}$ gas watch 1 ist double-she11 tanks (see Table 4-1). Therefore, the quantijty of fuel available for a burn is less than for the unmitigated case of $297 \mathrm{~m}^{3}$ and the tank will not experience the internal pressure necessary for dome collapse.

Consequences were calculated by allowing the gas to burn. This created a flow pattern in the headspace of the tank. It was assumed that there was waste material in the form of dry powder on the waste surface. This material is transported by the velocity profile set up by the ignited gas. The dome space loading was given originally as $0.39 \mathrm{~L}(0.64 \mathrm{~kg})$ in the vapor space plus $3.30 \mathrm{~L}(5.45 \mathrm{~kg})$ entrained by the deflagration for a total of $3.69 \mathrm{~L}(6.09 \mathrm{~kg})$ (LANL 1995).

It also was assumed that the HEPA filter was destroyed by the pressure pulse generated by the ignited gases. The amount of material on the filter

"Laboratory tests with crust material from two double-she11 flammable gas watchlist tanks were conducted. These showed that the crust material was not able to undergo an exothermic propagating reaction. Similarly, computer model ing has shown that, even for dry crust, an exothermic reaction cannot propagate. 
was assumed to be the same for every tank $(0.45 \mathrm{~L}[0.74 \mathrm{~kg}])$ and was added to the consequences calculated for the material resuspended from the waste surface.

The bounding source term ultimately released from a double-shell tank was $2.9 \mathrm{~L}(4.8 \mathrm{~kg})$ for tank 241-SY-101 (LANL 1995), including the contribution from the HEPA filter. The dose consequences were based on a conservative ULD estimate for several composites. These are the double-shell tank solid composite, the aging waste solid composite and the all solids composite (Savino, 1995, Van Keuren 1995). The radiologic and toxic dose consequences are reported in Table 5-2.

\subsection{CONCLUSIONS}

The Westinghouse Hanford Company Risk Acceptance Guidel ines, extracted from the Nonreactor Facility Safety Analysis Manual (WHC-CM-4-46), are used to determine acceptability of the consequences (see Tables 5-3 and 5-4).

Table 5-3. Radiological Risk Guidelines.

\begin{tabular}{|c|c|c|c|}
\hline \multirow{2}{*}{$\begin{array}{l}\text { Frequency } \\
\text { category }\end{array}$} & \multirow{2}{*}{$\begin{array}{c}\text { Frequency } \\
\text { range } \\
\left(y r^{-1}\right)\end{array}$} & \multicolumn{2}{|c|}{ Effective dose equivalent (mSv) } \\
\hline & & Onsite & Offsite \\
\hline Anticipated & $10^{0}$ to $10^{-02}$ & 50 & 5 \\
\hline Unlikely & $10^{-02}$ to $10^{-04}$ & 250 & 50 \\
\hline $\begin{array}{c}\text { Extremely } \\
\text { unlikely }\end{array}$ & $10^{-04}$ to $10^{-06}$ & 1,000 & 250 \\
\hline Incredible & $<10^{-06}$ & $>1,000$ & $>250$ \\
\hline
\end{tabular}

Table 5-4. Toxic Chemical Risk Guidelines.

\begin{tabular}{|c|c|c|c|}
\hline \multirow{2}{*}{$\begin{array}{l}\text { Frequency } \\
\text { category }\end{array}$} & \multirow{2}{*}{$\begin{array}{c}\text { Frequency } \\
\text { range } \\
\left(y r^{-7}\right)\end{array}$} & \multicolumn{2}{|c|}{ Primary concentration guidelines } \\
\hline & & Onsite & Offsite \\
\hline Anticipated & $10^{0}$ to $10^{-02}$ & $\leq$ ERPG-1 & $\leq \mathrm{PEL}-\mathrm{TWA}$ \\
\hline Unl ikely & $10^{-02}$ to $10^{-04}$ & $\leq E R P G-2$ & $\leq E R P G-1$ \\
\hline $\begin{array}{l}\text { Extremely } \\
\text { unlikely }\end{array}$ & $10^{-04}$ to $10^{-06}$ & $\leq E R P G-3$ & $\leq E R P G-2$ \\
\hline Incredible & $<10^{-06}$ & $>$ ERPG-3 & $>E R P G-2$ \\
\hline
\end{tabular}

The frequency for dropping sample material outside the tank was $2.2 \times 10^{-3}$ per core sampling. Both the maximum onsite committed effective dose equivalent for All Solids composite of $6.7 \mathrm{mSv}(0.67 \mathrm{mrem})$ and the maximum offsite committed effective dose equivalent of $3.7 \times 10^{-3} \mathrm{mSv}$ (0.37 mrem) are well below the corresponding radiological risk guidelines (see Table 5-4). Additionally, the maximum offsite toxic chemical sum-of-fractions of $2.0 \times 10^{-5}$ is also well below the corresponding risk acceptance guidelines. However, the maximum onsite toxic chemical sum-of-fractions is 2 , which is 
above the risk guidelines. NOTE: A sum-of-fractions is calculated when there are a number of toxic chemicals involved. The method involves taking the concentration of each toxic chemical and dividing it by the risk guideline value to obtain a fraction. The fractions then are summed. If the sum-offractions is less than or equal to I the risk guidelines are met and if the sum-of-fractions is greater than 1, the guidelines are exceeded. NOTE: The sum-of-fraction methodology does not account for synergisms between chemical species.

The frequency of dropping an instrument tree with a subsequent puncture of the tank liner is $2.7 \times 10^{-5}$ per lift. As stated in Section 5.2 , there are no immediate onsite or offsite dose consequences.

The annual frequency for ignition of flammable concentrations of gas is below $1 \times 10^{-6}$ per year (see Appendix A). At this frequency, the radiological consequences of $62,000 \mathrm{mSv}(6,200 \mathrm{rem})$ to the maximum onsite individual and $34 \mathrm{mSv}$ (3.4 rem) to the maximum offsite individual for a dome collapse are acceptable. Likewise, the toxicological sum-of-fractions of 25,000 for the maximum onsite individual and 0.45 for the maximum offsite individual for a dome collapse also are acceptable. However, if the administrative controls in Chapter 6.0 are not followed, the consequences would exceed the radiological and toxic chemical risk guidelines. 
WHC-SD-WM-SARR-002 REV 1

This page intentionally left blank.

$5-8$ 


\subsection{CONTROLS}

\subsection{GENERIC CONTROLS}

These controls apply to all activities performed in double-she11 tanks with flammable gas concerns. The controls found in Section 6.1.1, 6.1.2, 6.1.3, and 6.1.7 are considered operating safety requirement (OSR) level controls. All other controls are considered operating specification document controls, except for controls in Section 6.1.4 which are part of the Tank Farm Health and Safety Plan (Carls 1995) and Section 6.2 which are included in operating procedures.

\subsubsection{Ventilation Controls}

6.1.1.1 Ventilation Controls for SY Tank Farm. NOTE: These controls apply to tanks 241-SY-101, 241-SY-102, and 241-SY-103.

n The flow through tank 241-SY-101 shall be no less than $0.19 \mathrm{~m}^{3} / \mathrm{s}$ $\left(400 \mathrm{ft}^{3} / \mathrm{min}\right)$ and no more than $0.33 \mathrm{~m}^{3} / \mathrm{s}\left(700 \mathrm{ft}^{3} / \mathrm{min}\right)$. Exceptions to these requirements may occur occasionally for short periods of time because of difficulties balancing the tank airflows, for maintenance activities when backflow through the HEPA filters is of concern, or when switching from one exhauster to the other.

An example of the term "occasionally for short periods of time" is 8 hours, once per month ( 31 days).

- The combined minimum flow from tanks 241-SY-102 and 241-SY-103 shall be at least two-thirds the flow from tank 241-SY-101. Exceptions to these requirements may occur occasionally for short periods of time because of activities being performed in the tank farm.

- The exhauster flow rate and the tank 241-SY-101 ventilation flow rate shall be logged once a day. The rates shall be used to determine if controls 1 and 2 are being implemented.

- If the tank ventilation system fails or is shut down during the activity, the activity shall cease until the ventilation is restored (i.e., the primary exhauster is restarted or the primary exhauster is valved out and the secondary exhauster [or its equivalent] is valved in and started). If neither exhauster is functional, activity shall cease and the tank shall be placed in a safe condition.

- Upon breaking tank confinement in a particular riser for the first time during an activity, a pause in activities sha11 be observed. This allows any accumulated gases to be swept into the tank (the tank is kept at negative pressure, so the airflow will be from the outside to the inside). Appendix $C$ provides a method for calculating the time required for the purge. 


\subsubsection{Ventilation Controls for Other Tank Farms.}

- The tank ventilation system shall be operating before and during the activity. Exceptions to these requirements may occur occasionaliy for short periods of time because of difficulties balancing the tank airflows, for maintenance activities when backflow through the HEPA filters is of concern, or when switching from one exhauster to the other. An example of the term "occasionally for short periods of time" is 8 hours, once per month ( 31 days).

- If the tank ventilation system fails or is shut down during the activity, the activity shall cease until the ventilation is restored. If the exhauster cannot be restarted, the activity shall cease and the tank sha11 be placed in a safe condition.

- Upon breaking tank confinement in a particular riser for the first time during the activity, a pause shall be observed. This allows any accumulated gases to be swept into the tank (the tank is kept at negative pressure, so the airflow will be from the outside to the inside). Appendix $C$ provides a method for calculating the time required for the purge.

\subsubsection{Electrical Grounding and Bonding Controls}

NOTE: The electrical grounding and bonding controls would apply to all double-shell tanks with flammable gas concerns and to active tank ventilation systems which are not isolated from the tanks.

- Breaking confinement shall be performed in such a way as to prevent possible ignition of flammable gas because of static charges or mechanical sparks. Electrical bonding to the tank in accordance with the appropriate National Fire Protection Association code requirements for the classified regions of the tank vapor space and ventilation system shall be performed.

- To prevent mechanical sparks, only spark-resistant tools shall be used, except for the initial loosening (one full turn) and the final tightening (final torquing) of the bolts.

- All equipment inserted into the tank vapor space or ventilation system shall be electrically grounded and bonded in accordance with the appropriate National Fire Protection Association section code requirements for the classified regions of the tank vapor space and ventilation system.

\footnotetext{
* See Appendix D for definitions of NFPA-classified regions.
} 


\subsubsection{Hydrogen Concentration Control}

NOTE: The hydrogen concentration control applies to all double-shell tanks with flammable gas concerns. It is important to provide continuous measurements of the hydrogen concentration in the tank vapor space while activities are being performed.

This control can be satisfied by monitoring the tank using an installed flammable gas monitoring system, such as the standard hydrogen monitoring system and a hand-held combustible-gas meter. The wire-wrapped Tygon" or Tygon-equivalent hand-held combustible-gas meter would be positioned so that the sample is drawn from the tank vapor space below the riser 1 ip. In tanks without an installed flammable gas monitoring system, the control can be met using two hand-held combustible-gas meters.

- Monitoring systems shall be as close as practicable to the riser in which the activity is occurring.

- If the installed flammable gas monitoring system is not installed or are not functioning, the flammable gas concentration shall be taken at the following locations before starting an in-tank activity.

(1) After the riser bolts sealing the riser flange are loosened enough to take a gas sample from the riser, the concentration of flammable gases shall be taken at the riser opening.

(2) After complete riser cover removal and before the activity proceeds in the tank, a flammability test shall be conducted in the tank vapor space.

At each of these sampling locations, the following instructions should be followed. If any meter reading exceeds 25 percent of the lower flammability limit as developed in Appendix B and the activity warrants, a flow-through bulb sample shall be taken for specific gas species analys is in the laboratory, the activity shal1 cease, and the tank shall be placed in a safe condition. The activity shall not resume until results of a sample analys is are known, and the appropriate Safety and Tank Farm Project Management approvals are received.

- The flammable gas concentration shall be measured continuously during the in-tank activities with two independent, operable monitors (either with two installed flammable gas monitoring systems; with the installed flammable gas monitoring system and the hand-held combustible-gas meter; with two hand-held combustible-gas meters; or with some other comparable systems). For the standard

\footnotetext{
*Tygon is a trademark of Norton Company.

** An acceptable way of doing this is if the combustible-gas meter reading (calibrated on methane or pentane as appropriate to the specific meter) at the location in question is $\leq 25$ percent of the lower flammability 1 imit as indicated on the instrument display, the activity may proceed.
} 
hydrogen monitoring system, this is accomplished by viewing the strip chart recorder or the digital display. For the hand-held combustible-gas meter, the instrument shall be monitored continuously and readings shall be recorded every 15 minutes.

- Installation or removal activities in the tank shall cease and the tank placed in a safe condition when the flammable gas concentration exceeds a value equal to 25 percent of the lower flammability 1 imit (as developed in Appendix B) as read from any of the in-tank hydrogen monitoring probes, the hand-held combustible-gas meter(s) or other comparable instrumentation. Equipment designed to operate in flammable gas atmospheres can continue to function.

- Operations should ensure that any flammable gas monitors used for in-tank continuous monitoring during the intrusive activity shall be functioning properly.

- If the hydrogen concentration increases 500 ppm above the baseline (preactivity background level), the activity shall be placed on hold to see if the hydrogen concentration rise continues. If the hydrogen concentration continues to rise and there is a possibility that 25 percent of the lower flammability limit (as developed in Appendix B) may be surpassed, the tank shall be placed in a safe condition. If the hydrogen concentration remains stable or decreases, work can resume.

\subsubsection{Respiratory and Protection Controls}

NOTE: The respiratory and protection controls 1 isted below apply to all double-shell tanks with flammable gas concerns. The toxic gas monitoring will detect ammonia which the standard hydrogen monitoring system would not. NOTE: The Tank Farm Health and Safety Plan (Carls 1995) dictates controls for all tanks.

- The personnel working close to or around the open riser, open sample port, or any other opening in the tank or ventilation system, and those personnel elsewhere in the tank farm, i.e., the upwind staging area, shall wear respiratory protection as determined by the field representative of the Tank Waste Remediation System Industrial Hygiene Protection. The level of protection for those personnel will be based on the field measurements and the requirements in the Tank Farm Health and Safety Plan (Carls 1995).

- The toxic gas monitoring shall be performed in accordance with standard work practices contained in the Tank Farm Health and Safety Plan (Carls 1995). 


\subsubsection{Time of Intrusion}

\subsubsection{Time of Intrusion Controls for SY Tank Farm.}

- Since tanks 241-SY-101, -102 , and -103 have a common ventilation system, a burp in tank 241-SY-101 could introduce flammable gases into tanks 241-SY-102 and -103. Therefore, activities in/on tanks 241-SY-101, 241-SY-102, 241-SY-103, or the ventilation system shal1 occur any time during a 241-SY-101 intrusion window (Reynolds et al., 1993) and/or until the surface level of the waste in tank 241-SY-101 reaches the maximum allowable burp-level criterion (LANL 1995). If the activity is in progress when the maximum waste surface level in 241-SY-101 is reached, the activity may be completed.

The activity shall be conducted after observing a waiting time since the last 241-SY-101 mixer pump operation. The waiting time is given in the mixer pump safety assessment as 4 hours (see Appendix $Y$ of LANL 1995). This control includes the bump required to keep the pump in operating condition.

- Before conducting an activity, the tank measurements (i.e., temperature profile, strain gauges, background gas concentration, surface level) in 241-SY-101 shall have been steady for the required waiting time. During the entire activity, an operator will monitor the in-tank measurements and the closed-circuit television camera in tank 241-SY-101. If the activity is in 241-SY-103, an operator shall also monitor the in-tank measurements in 241-5Y-103. If any measurements provide indication that a gas release event is imminent, the tanks shall be placed in a safe condition, i.e., all openings shall be sealed and the tank farm shall be evacuated.

\subsubsection{Time of Intrusion Control for All Tank Farms.}

Work shall be done only after a review group has looked at recent tank behavior and decided that the tank is behaving in a manner consistent with its historical norm and there is no evidence that a gas release is expected during the time activity is to be conducted. This review group may have members from independent safety, operations (200 East or 200 West Area, as appropriate), process engineering, process control, safety analysis, plant engineering (200 East or 200 West Area, as appropriate), and safety programs. The minimum necessary for a decision are independent safety operations, safety analysis, and safety programs. This review will look at the past average behavior including any extremes (maximum or minimum) and compare it to recent behavior. If conditions exist outside of the normal behavior of the tank, a formal presentation will be made to the Plant Review Committee. This review group is not required for activities that are isolated from the tank vapor space. 


\subsubsection{Dome Loading}

Before this activity proceeds, it shall be ensured that the applicable Operational Specification Requirements for dome loading (both distributed and point loads) are satisfied for the tank on which the activity is occurring. This analysis will need to take into account all loads placed on the tank since the tank was certified to be in compliance with the Operational Specification Requirements. This includes new equipment, new concrete pads, new soil cover, etc., along with equipment needed to perform the activity such as cranes and trucks.

\subsubsection{Ignition Source Controls}

A program shall be in place to identify, evaluate, and eliminate, as appropriate, ignition sources in flammable gas tanks.

- Spark sources shall be identified and removed, replaced with rated equipment (see Appendix D), or deenergized if necessary.

- All tools and equipment used around the open rises that are small enough to fall through the riser shall be equipped with lanyards or other fall-protection devices.

- During insertion or removal of tall objects greater than $3 \mathrm{~m}$ $(10 \mathrm{ft})$, the objects shall be grounded to protect against lightning strikes. Grounding of a tall object provides a more favorable path for the lightning and may prevent electrical discharges within the tank.

- During insertion or removal of tall objects greater than $3 \mathrm{~m}$ $(10 \mathrm{ft})$, a weather watch shall be maintained. If lightning is present in an $80.5-\mathrm{km}$ (50-mile) radius around the tank farm where the activity is being performed, the tank will be placed in a safe shutdown condition.

- During installation and removal of equipment requiring crane or winch hoisting, the $1 \mathrm{ift}$ shall be treated as a critical lift.

- During installation and removal of equipment evaluated to be a potential ignition source if dropped, a means to prevent a drop of the equipment shall be installed.

- During installation and removal of electrical equipment, the equipment shall be de-energized unless specific evaluation determines that the energized state reduces risks of ignition sources.

- Equipment installation or removal shall be performed in a slow and deliberate manner, if resistance to movement is found, installation/ removal shall be halted and the source of resistance identified and corrected. 


\subsection{ACTIVITY-SPECIFIC CONTROLS}

The following controls are activity specific, i.e., the nature of the activity invokes their inclusion into the control section. The controls listed below have been previously approved in specific applications in conjunction with the controls identified in Section 6.1. Controls identified below will be imposed in operating procedures as important to safety.

\subsubsection{Standard Hydrogen Monitoring System}

- All components in the standard hydrogen monitoring system shall be inspected to ensure that they are installed properly and according to design requirements before operation of the system.

- The system shall be leak tested before initial startup of the system and when components of the system that contain or contact sample gases are replaced.

- All standard gas monitoring system drawings shall identify intrinsic safety features that must be maintained. No modifications will be made to any of these drawings without appropriate approvals.

- Each new hole drilled into the exhaust 1 ine shall be done with a new, sharp drill bit. During each drilling or tapping operation, a nonvolatile fluid (water) shall be used to aid in cutting and cooling the bit and the metal.

- Conductive plastic sheeting or some equivalent shall be used around the drilling operations to catch metal fragments. The material removed from the exhaust line will be considered to be contaminated.

\subsubsection{Still Photography or Closed-Circuit Television Camera}

\subsubsection{Still Photography.}

- Contamination control shall be provided around the open pump pit or open riser. The means of contamination control shall be specified in the applicable work package.

- Photographic equipment used, to include lighting and/or flash, shall conform to either the National Electric Code, Article 501 for use in Class 1, Division 2, Group B (flammable hydrogen environment) shal1 be purged with inerting gas in accordance with National Fire Protection Association, Inc., Article 496; or as also allowed by the National Fire Protection Association be designed to deenergize the camera system at a preset concentration $1 \mathrm{imit}$ such that the camera will not be operable when the tank is above 25 percent of the lower flammability limit at the camera. If the latter is chosen, analysis must show that the deenergized system can not cause ignition through residual heat, capacitor discharge, or other electrical discharge. The purge gas system, if used, shall have dual safety 
instrumentation to alarm and automatically shut off all electrical power to the electrical components served by the purge gas system if a lost of gas pressure occurs.

- Photographic hardware shall be of spark-resistant materials, such as stainless steel.

- A stainless steel insert with a static resistant plastic liner shall be used to protect the tank riser and to keep the photographic equipment from becoming contaminated.

- The photographic equipment shall provide for tank containment at the open riser (e.g., glovebag, greenhouse, or special riser cover).

\subsubsection{Closed Circuit Television Camera.}

- The pressure in the tank during the installation activities shall be maintained within the current operating requirements for the tank. This may be accomplished by using the confinement seal fixture.

- Before the installation of the shield plug/closed-circuit television camera assembly, the complete purge cycle shall be completed. The purge cycle will flush the total enclosure volume with a minimum of 10 volumes. During installation and operation, the enclosures shall be pressurized at $3.7 \mathrm{kPa}(0.5 \mathrm{psi}$ or $15-\mathrm{in}$. water gauge). The lowpressure transducer provides an interlock at $2.5 \mathrm{kPa}(0.33 \mathrm{psi}$ or 10-in. water gauge) to shut down electrical power.

- Before installation of the shield plug/closed-circuit television camera assembly, a complete operational check (including the al arm and interlock systems) shall be performed.

- The shield plug/closed-circuit television camera assembly shall be removed periodically (based upon the experience with the tank 101-sy television camera) to undergo preventative maintenance or repair. Corrosion, radiation-induced glass browning, and seal wear are major inspection areas. Maintenance may include the television camera, the lights, the light enclosure, or other component replacement.

\subsubsection{Grab Sampling}

- The riser shall be inspected for obstructions before installation of the grab sampling assembly. Methods that could cause sparks or provide an ignition source in the tank or riser shall not be used. Excessive radiation exposure to workers should be avoided.

\subsubsection{Auger Sampling}

- During manual installation, one lifting bar sha11 be in place at all times. 


\subsubsection{Push-Hode Sampling}

- A maximum of $950 \mathrm{~L}(250 \mathrm{ga} 1)$ of treated water with a 1 ithium bromide tracer can be used during push-mode sampling for each complete core. If it is necessary to exceed this amount of water, permission must be obtained from Tank Farm Operations and Nuclear Safety.

- The hydraulic safety interlock that prevents penetration through the bottom of the tank shall be tested to ensure that it is functioning before sampling of the tank waste. The hydraulic safety interlock shall be engaged immediately before the last (determined by calculations) core segment is taken.

- The core drill truck shall not be modified to allow more pressure, i.e., $1.7 \mathrm{MPa}\left(250 \mathrm{lbf} / \mathrm{in}^{2}\right)$, or more downward force than the currently allowed $23.7 \mathrm{kN}(5,300 \mathrm{lbf})$ for push-mode core sampling.

- The old push-mode core sampling truck shall disengage rotary-mode capability using established lock and tagout procedures.

- The drill string shall be sampled for flammable gases after each inactive period of time while the drill string is open at the bottom (i.e., there is no sampler). If the concentration is greater than 25 percent of the lower flammability limit, the drill string is to be vented and/or purged. Work can continue after two consecutive measurements are less than 25 percent of the lower flammability 1 imit.

\subsubsection{Multifunction Instrument Tree}

- A maximum of 950 L (250 gal) of treated water can be used for insertion of the multifunction instrument tree. If it is necessary to exceed this amount of water, permission must be obtained from Tank Farm Operations and Nuclear Safety.

\subsubsection{Routine Maintenance}

- Before the removal of pump pit cover blocks or before any intrusive work into the pump pit, the pump pit shall be sampled for flammable gases since the pit has open drains to the tank. If the concentration in the pump pit is greater than 25 percent of the lower flammable limit, the activity shall cease and the pump pit shall be vented by opening any access ports or removing any sealing material around the pump pit cover blocks. The activity shall not resume until the reading is below 25 percent of the lower flammability 1 imit. 
WHC-SD-WM-SARR-002 REV 1

This page intentionally left blank.

6-10 


\subsection{REFERENCES}

Antoniak, Z. I., and K. P. Recknagle, 1995, Modeling of Post-GRE Spacial and Temporal Hydrogen Concentrations in Waste 241-AW-101 Dome, WTSFG95.27, Pacific Northwest Laboratory, Richland, Washington.

Atencio, J. K., 1992, System Description Standard Hydrogen Monitoring Systems, WHC-SD-WM-SDD-001, West inghouse Hanford Company, Richland, Washington.

Braun, D. J., L. D. Muhlestein, T. B. Powers, and M. D. Zentner, 1994, HighLevel Waste Tank Subcriticality Safety Assessment, WHC-SD-WM-SARR-003, Wẹtinghouse Hanford Company, Richland, Washington.

Babad, H., 1991, Evaluation of the Generation and Release of Flammable Gases in Tank 241-SY-101, WHC-EP-0517, Westinghouse Hanford Company, Richland, Washington.

Babad, H., 1991, Mitigation/Remediation Concepts for Hanford Flammable Gas Generating Waste Tanks, WHC-EP-0516, West inghouse Hanford Company, Richland, Washington.

Carls, D. R., 1995, Tank Farm Health and Safety Plan, WHC-SD-WM-HSP-002, Rev. 2D, Westinghouse Hanford Company, Richland, Washington.

Christensen, G. M., 1992, Safety Documentation for Non-Pump Work in Tank 241-SY-101, Window G, (external letter \#9255759 to R. E. Gerton (RL), dated July 31), Westinghouse Hanford Company, Richland, Washington.

Deere, D. C., 1991, Safety Assessment for Operation of the Temporary Gas Monitoring System in Tank 101-SY, WHC-SD-WM-SAD-007, West inghouse Hanford Company, Richland, Washington.

DOE, 1986, Disposal of Hanford Defense High-Level, Transuranic and Tank Wastes, EIS-0113 (Vol. 3), Draft Environmental Impact Statement, U.S. Department of Energy, Washington, D.C.

DOE, 1994, Environmental Assessment (EA) and Finding of No Significant Impact (FONSI) for the Waste Tank Safety Program at the Hanford Site (DOE/EA-0915), (DOE Letter from T. O'Toole, Assistant Secretary for Environment, Safety and Health, to T. P. Grumbly, Assistant Secretary for Environmental Restoration and Waste Management, dated February 25), U.S. Department of Energy, Washington, D.C.

DOE-RL, 1992, Hanford Hoisting and Rigging Manua7, DOE/RL-92-36, U.S. Department of Energy, Richland Field Office, Richland, Washington.

Farley, W. G., 1994, Safety Assessment for Installation and Operation of Thermocouple Trees in Ferrocyanide Tanks, WHC-SD-WM-SAD-014, Rev. 3, Westinghouse Hanford Company, Richland, Washington.

Farley, W. G., 1996, Video in Hanford Waste Tanks Using the Mobile Color Camera System, USQE TF-94-0103, Westinghouse Hanford Company, Richland, Washington. 
Jones, K. M., 1994a, Structural Analys is of Tank 241-SY-101 Nulti-Functional Instrument Tree, WHC-SO-WM-DA-112, Westinghouse Hanford Company, Richland, Washington.

Jones, K. M., 1994b, Waste Tank Video Camera Assembly Stress Analysis, WHC-SD-WM-DA-145, Westinghouse Hanford Company, Richland, Washington.

LANL, 1994, Double-Shell Tank Bounding Analysis, LA-UR-94-2088, Rev. 0, Los Alamos National Laboratory, Los Alamos, New Mexico.

LANL, 1995, A Safety Assessment for Proposed Pump Mixing to Mitigate Episodic Gas Releases in Tank 241-SY-101: Hanford Site, Richland, Washington, LA-UR-92-3196, Rev. 14, Los Alamos National Laboratory, Los Alamos, New Mexico.

Leach, C. E., and S. M. Stahl, 1993, Hanford Site Tank Farm Facilities Interim Safety Basis, Volume 1 \& Volume 2, WHC-SD-WM-ISB-001, Rev. 0-I, West inghouse Hanford Company, Richland, Washington.

Marusich, R. M., 1990, Safety Evaluation for Sludge Level Weight, Manual Tape, and FIC Removal from Tank 101-SY, EDT 154571, Westinghouse Hanford Company, Richland, Washington.

Marusich, R. M., D. C. Deere, and R. J. Van Vleet, 1991, Safety Assessment for Window B Activities in Tank 101-SY, WHC-SD-WH-SAD-003, Rev. 3, Westinghouse Hanford Company, Richland, Washington.

Marusich, R. M., 1991a, Push Mode Core Sampling Safety Assessment, WHC-SD-WM-SAD-008, Rev. O-A, West inghouse Hanford Company, Richland, Washington.

Marusich, R. M., 1991b, Safety Assessment for the 101-sY Ventilation Upgrades, WHC-SD-WM-SAD-012, Westinghouse Hanford Company, Richland, Washington.

Milliken, N. J., 1995, Safety Analysis for Push- and Rotary-Mode Core Sampling, WHC-SD-WM-SARR-031, Rev. 1, West inghouse Hanford Company, Richland, Washington.

Murthy, K. S., L. A. Stout, B. A. Napier, A. E. Reisenauer, and D. K. Landstrom, 1983, Assessment of Single-Shell Tank Residual Liquid Issues at Hanford Site, Washington, PNL-4688, Pacific Northwest Laboratory, Richland, Washington.

NFPA, 1993, National Electrical Code, NFPA 70, Article 500-3, National Fire Protection Association, Quincy, Massachusetts.

NFPA, 1993, Purged and Pressurized Enclosures for Electrical Equipment, NFPA 496, National Fire Protection Association, Quincy, Massachusetts.

NUREG, 1980, Control of Heavy Loads at Nuclear Power P7ants, NUREG-0612, U.S. Nuclear Regulatory Commission, Washington, D.C. 
Powers, T. P., 1992, Calculations of the Probability of Ignition of a Flammable Hydrogen Mixture During Window G Activities Caused by a Lighting Strike on the SY Tank Farm, (internal memo \#29220-92-TBP-030 to - J. M. Grigsby, R. W. Reed, G. D. Johnson, and G. M. Christensen, dated July 9), Westinghouse Hanford Company, Richland, Washington.

Resource Conservation and Recovery Act of 1976, 42 USC 6901 et seq.

Reynolds, D. A., W. Kubic, R. D. Crowe, and R. J. Van Vleet, 1993, Technical Basis for Selection of Tank 101-SY Intrusion Window, WHC-SD-WM-TI-458, Westinghouse Hanford Company, Richland, Washington.

Reynolds, D. A., 1994, Evaluation of 241-AN Tank Farm Flammable Gas Behavior, WHC-EP-0717, West inghouse Hanford Company, Richland, Washington.

Rogers, C. A., 1994, CSER-94-001: Criticality Safety of Double-Shell Waste Storage Tanks, WHC-SD-SQA-CSA-20368, Westinghouse Hanford Company, Richland, Washington.

"Safety Measures for Waste Tanks at Hanford Nuclear Reservation," Section 3137 of National Defense Authorization Act for Fiscal Year 1991, Public Law 101-510, November 5, 1990.

Smith, D. A., 1986, Single-Shell Tank Isolation Safety Analysis Report, SD-WM-SAR-006, Rev. 2, Rockwell Hanford Operations, Richland, Washington.

Sontag, S. P., 1991, Safety Assessment for TV Camera and Lights Installation, Operation, and Removal in Tank 101-SY, WHC-SD-WM-SAD-005, Rev. 2, Westinghouse Hanford Company, Richland, Washington.

Stone, W. A., J. M. Thorp, 0. P. Gifford, and D. J. Hoitink, 1983, Climatological Summary for the Hanford Area, PNL-4622, Batte1le Pacific Northwest Laboratory, Richland, Washington.

Vail, T. S., 1992, Justification for Continued Operations of Hanford HighLevel Waste Tanks Resulting from the Criticality USQ, 492-CRITSAF, WHC-SD-WM-JCO-001, Rev. 0, West inghouse Hanford Company, Richland, Washington.

Van Keuren, J. C., 1995, XXX, Westinghouse Hanford Company, Richland, Washington.

Van Vleet, R. J., 1991, Safety Assessment for Penetrometer Testing and Auger Sampling in Tanks that Generate Flammable Gases, WHC-SD-WM-SAD-004, Rev. 2, Westinghouse Hanford Company, Richland, Washington.

Van Vleet, R. J., 1993a, Radionuclide and Chemical Inventories for the Double Shell Tanks, WHC-SD-WM-TI-543, Rev. 1, Westinghouse Hanford Company, Richl and, Washington.

Van Vleet, R. J., 1993b, Transmittal of USQ Screening/Safety Evaluation for Installation and Operation of Additional MITs in Tank 101-SY, (internal letter \#29120-RJVV-93033 to R. R. Grantham, dated Apri1 30), Westinghouse Hanford Company, Richland, Washington. 
Weadon, A. M., 1992, Lightning Protection of Underground Storage Tank 101-SY Inquiry \#W-168884 Final Report, (external letter to G. M. Christensen, dated July 2), Electric Research \& Management, Inc., State College, Pennsylvania.

WHC, 1993, Perform Installation of New or Modified Large Equipment in Tank Farms, Tank Farm Operating Procedure T0-020-250, Westinghouse Hanford Company, Richland, Washington.

WHC, 1995, Interim Chapter 3.0 Hazard and Accident Analysis, WHC-SD-WM-SAR-065, Westinghouse Hanford Company, Rich1 and, Washington.

WHC, 1996, Operating Specification for Watch List Tanks, OSD-T-151-00030, Rev. B-16, Westinghouse Hanford Company, Richland, Washington.

WHC-CM-4-46, Safety Analysis Manual, Westinghouse Hanford Company, Richland, Washington.

WHC-CM-7-5, Environmental Compliance, Westinghouse Hanford Company, Richland, Washington.

Wilkins, N. E., 1994, Evaluation of Tank 241-AW-101 Flammable Gas Behavior, WHC-SD-WM-TI-617, Rev. 0, Westinghouse Hanford Company, Richland, Washington. 
WHC-SD-WM-SARR-002 REV 1

APPENDIX A

FREQUENCY OF OCCURRENCE OF IGNITION 
WHC-SD-WM-SARR-002 REV 1

This page intentionally left blank. 
WHC-SD-WM-SARR-002 REV 1

APPENDIX A

FREQUENCY OF OCCURRENCE OF IGNITION

\subsection{INTRODUCTION}

This appendix contains a qualitative, semiquantitative argument to determine the frequency of ignition for the flammable gas tanks. This appendix applied to both double-shell and single-shell tanks. This is done because the type of analysis done for either tank is similar, the types of flammable gases are similar, and the types of equipment used are similar.

\subsection{PROBABILITY OF IGNITION SOURCES}

This section will be divided into two subsections. One on external ignition sources and one on internal ignition sources. These are discussed below.

\subsection{EXTERNAL EVENTS}

The Hanford Waste Vitrification Plant Preliminary Safety Analysis Report (Herborn 1991) examined the potential for flooding the 200 Areas (both the 200 East and 200 West Areas). Probable maximum floods on streams and rivers, surge and seiche flooding, flooding from ice dams, flooding from tsunamis, and flooding from dam failures were analyzed. The worst-case flood was found to be caused by a hypothetical direct-hit detonation of a nuclear warhead on the Grand Coulee Dam. In that scenario, the floodwaters would peak at an elevation of $140.2 \mathrm{~m}(460 \mathrm{ft})$. This is well below the $213.4-\mathrm{m}(700-\mathrm{ft})$ elevation of the 200 Area. As a result, flooding is eliminated as an external ignition initiating event.

A range fire as an external ignition initiating event can be eliminated from consideration for two reasons. First the tank farms are kept clear of vegetation and are surrounded by fences that will keep out most burning debris. Even in the event burning debris enters a tank farm, there are no combustible materials stored in the farm. Second, there are no mechanisms to propagate a fire back into a tank. For example, tank 241-SY-101 has been classified according to National Fire Protection Association provisions (NFPA 1993). The vapor space is Class 1, Division 2, Group B, whereas outside the tank on the top is considered a nonclassified region. Additionally, a flame front could not propagate back into the tank unless the concentration would support downward propagation. For hydrogen, this concentration is 9.0 percent (well above the maximum measured concentration of 5.1 percent). For the slurry gas mixture presented in Appendix B, this may not be true. Measurements of the downward, horizontal, and upward propagation 1 imits are being conducted during fiscal year 1996. Therefore, range fires are eliminated as an external ignition initiating event. 
High winds are not considered a credible external ignition initiating event. The tanks are buried in the ground and are not susceptible to windborne missiles. Additionally, flammable concentrations could not exist outside of the tank during the high winds, and a flame front could not propagate back into the tank because of the required hydrogen concentration for downward flame propagation (see paragraph above). Tornadoes also were evaluated by Herborn (1991). Tornadoes are rare in the Pasco Basin, and on the average, the State of Washington experiences just over one tornado per year. Additionally, as specified by the U.S. Department of Energy in Design and Evaluation Guidelines for Department of Energy Facilities Subjected to Natural Phenomena Hazards (DOE 1989), is used for nonreactor facilities. This document says that tornadoes are not considered a viable threat or hazard at the Hanford Site. Dust devils are another wind phenomena. These occur frequently during the summer months. Dust devils have a short lifespan and are believed to have low wind speeds as compared to tornadoes. The consequences of any missiles generated are bounded by those generated by high winds. Consequently, high winds, tornadoes, and dust devils are eliminated as an external ignition initiating event.

Herborn (1991) also examined the volcanic hazards for the 200 Areas. In the report, it is stated that there is no evidence of lava flows, ash flows, or mudflows from Cascade Range volcanoes having reached the Pasco Basin during the Quaternary period. The nearest Cascade Range volcano is $96.6 \mathrm{~km}(60 \mathrm{mi})$ from the Hanford Site. Most eruption products remain within $48.3 \mathrm{~km}$ (30 mi) of the Cascade Range volcanoes. The only exceptions are mudflows and ashfa11. The mudflows tend to follow existing drainage channels, and since there are no streams flowing directly from the Cascade Range to the Hanford Site, this volcanic hazard is not considered credible. Ashfall is considered for structural purposes; however, the ashfall is not considered as a ignition source. As a result, volcanic activity is eliminated as an external ignition initiating event.

The annual frequency for a large earthquake $(0.2 \mathrm{~g})$ is given as $5 \times 10^{-4}$ per year (Tallman 1994). Two cases will be evaluated, one during normal operations (storage of the waste) and one during an activity in the tank. For the case of normal operations, the earthquake might cause a tank to have a gas-release event. However, there is a time delay between the jolt to the tank and the gas being released into the vapor space. For example, in tank 241-SY-101, it was calculated that it took 2 minutes for the gas to move from the bottom of the tank to the headspace during a rollover-type gas release event.

Some of the permanent equipment installed in the tank, such as thermocouple trees, 1iquid observation wells, and salt well screens are secured at the top (by being bolted to the riser flange) and at the bottom (by being inserted in the waste matrix). Generally the waste matrix is made up of solids, for example, salt cake or sludge in the single-shell tanks or settled solids or slurry in double-shell tanks. Therefore, one could expect that the tank, the equipment, and the waste would move together during the earthquake. other equipment, such as siudge weights, manual tapes, Food Instrument Corporation level probes, and Enraf displacement probes, may be able to move during the earthquake. However, even if they did move, they would have to be able to travel some distance to impact other equipment in the tank or the tank walls. Typically, this would be a distance of 3.1 to $4.6 \mathrm{~m}$ (10 to $15 \mathrm{ft}$ ). 
After earthquakes, aftershocks typically occur. These are usually smaller in magnitude. The same arguments about equipment movement holds true.

Because there are no credible ignition sources in the vapor space during normal operations (see discussion below) and because any equipment movement would have occurred when the earthquake struck, this ignition is not considered credible. For the second case, assuming that tank activities last 8 hours, the probability of an earthquake occurring during that time is given by

$$
\begin{aligned}
P & =\left(\frac{8 \mathrm{hr}}{\left(24 \frac{\mathrm{hr}}{\mathrm{day}}\right)\left(365 \frac{\mathrm{day}}{\mathrm{yr}}\right)}\right)\left(\frac{5 \times 10^{-4}}{\mathrm{yr}}\right) \\
& =4.6 \times 10^{-7} .
\end{aligned}
$$

For example, for 2 8-hour activities in the tank (or any combination of activities totaling 14 hours), the annual frequency would still be less than $1 \times 10^{-6}$ per year ( $\mathrm{i} . \mathrm{e} .$, it is in the incredible category). However, 18 hours of activity brings you into the highly unlikely category. No single tank has activities performed for a duration of 18 hours. Therefore, earthquakes are eliminated as external initiating events.

Lightning as an ignition source has an estimated frequency of $4.52 \times 10^{-4}$ per year per tank (Cowley 1994). Cowley (1994) indicates that if protection against lightning strikes is taken (an example includes the measures found in military standard MIL-B-5087B), this frequency might be reduced. Using the method as shown above, lightning strikes during activities that last for less than a cumulative total of 20 hours are incredible (frequency of lightning during the time of activity coupled with the frequency of flammable gas being present in concentrations above 25 percent of the lower flammable 1 imit averaged over the total vapor space is $\left.<1 \times 10^{-6}\right)$. No single tank has activities performed for a duration of 20 hours. Thus, 1ightning is eliminated as an external initiating event during an activity (NOTE: Two controls are still imposed because a thunderstorm at the Hanford Site can develop with no warning in less than 1 hour). However, 1 ightning during normal operation (storage of the waste) is still a credible external initiating event.

\subsection{INTERNAL EVENTS}

In this section, it will be assumed that known spark sources in the tanks have been removed or deenergized (See Section 6.1.7 of this document).

Powers and Morales (1994) was reviewed for internal events. The following paragraphs, which are excerpted from Van Vleet (1994), discuss how the data were manipulated and provide the technical basis for the manipulation. This section covers both normal operation (storage of the 
waste) and activities in the tanks (e.g., photography using equipment rated for Class I, Division 2, Group B; sampling and installation of monitoring equipment).

The first manipulation was to correct the probabilities to a per event basis. To do this, the probabilities in Powers and Morales, Appendix E (1994) were divided by 3.65 , the average number of gas releases that tank 241-SY-101 had before the mitigation mixer pump was installed. This information is presented in Table A-1.

Table A-1. Ignition Frequency for Flammable Gas Tanks.

\begin{tabular}{|c|l|c|c|c|}
\hline Cutsets & \multicolumn{1}{|c|}{ Description } & $\begin{array}{c}241-S Y-101 \\
\text { frequency }^{\mathrm{a}}\end{array}$ & $\begin{array}{c}\text { FG DST } \\
\text { frequency }^{\mathrm{b}}\end{array}$ & $\begin{array}{c}\text { FG SST } \\
\text { frequency }^{\mathrm{b}}\end{array}$ \\
\hline 5 & $\begin{array}{l}\text { Electrical sparks from } \\
\text { explosion-proof lights, or } \\
\text { faults in the electrical } \\
\text { leads to the lights. }\end{array}$ & $1.31 \times 10^{-3}$ & 0.00 & NA \\
\hline 9 & $\begin{array}{l}\text { Mechanical sparks caused by } \\
\text { metal striking metal in the } \\
\text { tank. }\end{array}$ & $3.65 \times 10^{-4}$ & $1.00 \times 10^{-4}$ & $1.00 \times 10^{-4}$ \\
\hline 10 & $\begin{array}{l}\text { Mechanical sparks from } \\
\text { sludge-level-weight cable } \\
\text { striking gas monitoring } \\
\text { probes. }\end{array}$ & $3.65 \times 10^{-4}$ & 0.00 & 0.00 \\
\hline 11 & $\begin{array}{l}\text { Electrical sparks from } \\
\text { operation of the FIC level } \\
\text { measurement device. }\end{array}$ & $2.19 \times 10^{-4}$ & 0.00 & 0.00 \\
\hline Total & \multicolumn{1}{|c|}{ - } & $2.26 \times 10^{-3}$ & $1.00 \times 10^{-4}$ & $1.00 \times 10^{-4}$ \\
\hline
\end{tabular}

Assumes 3.65 gas-release events per year.

'Assumes one gas-rel ease event per year. credible.

this failure, or that of any of the other level-measurement instruments, is no longer considered hitting one another and causing sparks.

DST = double-shell tank.

SST = single-shell tank.

$F G=f$ lamable gas.

FIC = Food Instrument Corporation.

In the normal storage mode, the potential ignition sources for either single-shell or double-she11 flammable gas tanks are the same. These potential sources are the ventilation system; permanent closed-circuit television cameras (double-shell tanks only); the level-indicating instrument; and the thermocouple tree. These systems are described below, and where appropriate, credit is taken for meeting the NFPA requirements for potentially 
flammable atmospheres (NFPA 1993). In the activity mode, credit will be taken for the use of ignition-source prevention controls and for flammable gas monitoring during all activities.

A11 cutsets dealing with external to the tank ignition sources (i.e., the sources in the ventilation system) were removed. This was done because propagation of a flame through the duct and into the tank would not occur unless the concentration of hydrogen was at the concentration that supported downward propagation of the flame front. This limit is 9.0 volume percent for hydrogen in air (Coward and Jones 1952). This is well above the peak hydrogen concentration ever measured in tank 241-SY-101, 5.1 volume percent. For the slurry gas mixture presented in Appendix B, this may not be true. Measurenents of the downward, horizontal, and upward propagation limits are being conducted during fiscal year 1996. However, the other double-shell tanks apparently have significantly smaller gas-release events (as evidenced by the surface level drops and the absence of pressure pulses). Therefore, the hydrogen concentration in tank 241-SY-101 is used as a bound for the hydrogen concentration in the other flammable gas double-shell tanks.

The removal of external ignition sources is still justified. There are no ignition sources in the ventilation system except at the exhauster. The exhauster has basically four potential ignition sources: the heater elements, the fan blade, the fan bearings, and the radiation monitoring equipment in the stack. For these to be ignition sources, they must fail or malfunction while a flammable concentration of gas is present. Additionally, because the ventilation systems serve multiple tanks, air is pulled from the other tanks (three tanks in the SY farm, 13 tanks in the SX farm, seven tanks in the AN farms, and six tanks in the AN farm) and the actual concentration arriving at the exhauster is less than that in the vapor space of the tank having a gas-release event. Additionally, the bounding gas-release event from tank 241-SY-101 is no longer deemed a credible event since a mitigation option (mixer pump) was chosen and implemented in 1993. As required by the U.S. Department of Energy, Richland Operations Office, the mixer pump must continue the mitigation by mixing pump operation (Sidpara 1995). The remaining cutsets (Powers and Morales 1994, PE-4) are represented in Table A-1.

The cutset for electrical sparks caused by the explosion-proof lights or the electrical leads to the lights has been eliminated. This is because originally certain design features were not taken into account. With these design features included in the analysis, the ignition frequency becomes $<1 \times 10^{-6}$ (Scaief 1994).

"The SX farm is the only single-shell tank farm actively ventilated. Only 13 of the $15 \mathrm{SX}$ farm tanks are actively ventilated. An exhauster also ventilates tanks 241-C-104, 241-C-105, and 241-C-106 in the C farm. The SY, $A N$, and AN are among the double-shel1 tank farms. 
Some of the Food Instrument Corporation level-indicating devices have been outfitted with a slack-tape switch. This is a known spark source and must be removed on flammable gas tanks. It is assumed that this has been done (see Section 6.1.7) so that the cutset for the operation of the Food Instrument Corporation level-indicating device has been eliminated also. A more thorough review of the Food Instrument Corporation level-indicating device (Scaief 1994) indicated that it could not fail in the manner that was originally assumed. Other means of in-tank level measurement (displacement gauge, manual tapes, and zip cords) have been evaluated and determined not to be spark sources (Scaief 1994).

A potential safety concern was sparking or resistive heating of thermocouples in the waste. A thermocouple produces a voltage proportional to the difference in temperature between the thermocouple junction and the reference junction (voltmeter location). Because the thermocouples are grounded, the only credible mechanism for an electrical arc is to have one of the thermocouple wires break, and at the same time a high voltage to be accidently applied to the thermocouple leads. There is little chance of this happening because the signal conditioner hooked up to the thermocouples operates on 12. or 15 volts DC. Significant resistive heating of a thermocouple would require high current flow through the thermocouple, which in turn would require high voltage applied to low impedance. This also has little chance of happening because thermocouples have an impedance of 10 to 100 ohms distributed over the entire length of the thermocouple. If 15 volts $D C$ were accidently connected to a thermocouple, the potential exists for 0.15 to $1.5 \mathrm{~A}$ of current to flow through the thermocouple and heat the wiring a few degrees. Such heating would be distributed over the entire length of the thermocouple wire and would present no safety hazard. Also, any spark or resistive heating would be confined by the thermocouple sheath, tubing, and pipe in the interior thermocouples of the thermocouple tree. External thermocouples would have only the thermocouple sheath for a barrier.

A platinum resistance temperature detector produces a change in resistance proportional to the temperature of the extension wire and the measuring termination point. The typical resistance of a resistance temperature detector is about 100 ohms. Assuming a typical excitation current of $0.5 \mathrm{~A}$, the resistance temperature detector at $50{ }^{\circ} \mathrm{C}\left(120{ }^{\circ} \mathrm{F}\right)$ would have a resistance of $120 \mathrm{ohms}$ and would produce about $0.03 \mathrm{~mW}$ of heat energy (Scaief 199la). This heat would be dissipated by the surrounding sheath and would be inconsequential. The resistance temperature detectors in the protective sheath will be qualified for use in a National Fire Protection Association, Class 1, Division 1, Group B hazardous location (Scaief 1991b). Therefore, there is no cutset dealing with the instrument tree being an ignition source.

As mentioned above in the External Events section, the instrument tree, liquid observation well, or the salt well screen could be one of many ignition sources (either in the vapor space or subsurface) if the tank were struck by lightning. However, as mentioned above, if protection against lightning strikes is taken (similar to the measures found in military standard MIL-B-5087B) this frequency might be reduced.

Another subsurface spark source could be the push-mode sampling apparatus if it were struck by lightning. However, lightning strikes during 
activities have been shown to be incredible (frequency of lightning during the time at risk coupled with frequency of flammable gas is $<1 \times 10^{-6}$ ). Furthermore, the sampling truck is grounded and bonded for lightning strikes. Spark sources during the use of the sampling equipment itself have been administratively controlled (see discussion below).

In this section of this appendix, it was shown that there is only one external spark source of concern and that the operating equipment (level-measuring equipment and the temperature-monitoring equipment if the actions described in Section 6.1.7 are taken) in the tank is not considered to be a source of sparks. For a deflagration to occur, the ignition source must exist in the same location as the flammable concentration of released gases. Thus, the internal ignition sources being dealt with are mechanical sparks caused by metal striking metal in the tank. This type of ignition source could occur in the tank during normal storage mode if tank equipment during a gas-release event was affected in such a manner as to cause it to impinge upon the tank wall. Sludge weights (obsolete equipment consisting of a small metal weight on a long cable) have been postulated to swing into the wall. In tank 241-SY-101, sludge weights were observed (via the closed circuit television camera) to move around (but not swing free of the waste) during the roll-over events. The postulated maximum gas-release events in a11 the double-shel1 flammable gas tanks are less than the gas-release volume postulated to occur during a tank 241-SY-101 activity window before the mitigation mixer pump was installed (see also the $2445 \mathrm{~m}^{3}$ burn analys is in LA-UR-92-3196, LANL, 1995. However, the sludge weight will move away from the upwelling during a partial or local gas-release event. Thus, even if it does strike a wall, it may not have enough energy to cause a spark and even if it does, the spark would occur away from the highest concentrations of flammable gas, potentially in a region that is nonflammable. Another concern associated with the sludge weights moving during a gas-release event was frictional heating caused by the cable rubbing on the riser 1ip. A similar analysis for a stainless steel probe was analyzed and determined to be an incredible ignition source (Marusich et a1. 1991). The sludge weights have been removed from tank 241-SY-101.

Movement of thermocouple trees also was observed in tank 241-SY-101 during gas-release events. Evidence of this behavior was postulated before actually seeing it because of the bends in the thermocouple tree. The thermocouple tree in tank 241-SY-101 was removed, and it was replaced with a sturdier multifunction instrument tree. Recent in-tank videos of tanks 241-SY-103 and 241-AW-101 do not show any bends in the thermocouple trees. The postulated maximum gas-release events in all the double-shell flammable gas tanks are less than the gas-release volume postulated to occur during a tank 241-SY-101 activity window before the mitigation mixer pump was installed. Thus, spark sources caused by movement of equipment in the doubleshel1 tanks during a gas-release event is considered to be not credible.

The single-shell flammable gas tanks have behavior that is significantly different than that of tank 241-SY-101. These tanks have not had rollovertype gas release events (a conclusion drawn from surface-level data only because temperature data are not taken frequently enough to provide useful information, and pressure data are nonexistent). Additionally, gas-release events that cause the waste to roll over (a rapid exchange of waste in the bottom layers of the tank with the waste in the upper layers) do not appear to be credible events. Calculations on postulated gas storage and release 
mechanisms show that if a gas-release event occurred in a single-shell tank it would likely take a long time (Allemann et al. 1995). Other mechanisms for storage and release are discussed in Section 1.3 of this document. Additionally, the release most likely would not be a complete tank rollover (similar to 241-SY-101), simply because the waste types generally are different (solids, sludges, and salt cakes versus sludges and liquids). Thus, spark sources caused by movement of equipment in the single-shell tanks during a gas-release event are considered to be not credible.

Thus, the only internal ignition sources of concern are those generated during an activity. To minimize these ignition sources, a number of administrative controls have been imposed on operations in flammable gas tanks. These include, but are not limited to, grounding and bonding to prevent electrostatic sparks; grounding and bonding tall objects ( $3 \mathrm{~m}$ or more in length) for protection against lightning; use of spark-resistant materials, using spark-resistant tools; and minimizing frictional heating or mechanical sparking. With these controls in place, an engineering judgment is made that a probability of $1 / 10,000$ for ignition sources being present is reasonable.

\subsection{PROBABILITY OF FLAMMABLE GASES BEING PRESENT}

The next subject that needs to be addressed is the probability of flammable gases in ignitable concentrations. For tank 241-SY-101, the probability that the entire vapor space contained flammable gases at concentrations that could be ignited during each gas-release event was taken as one. This has been shown to be a correct assumption for tank 241-SY-101. During the releases in the tank, monitoring was performed on the gas probe assemblies (Reynolds 1994). The first test measured the hydrogen concentration at three probe positions $45.72 \mathrm{~cm}$ (18 in.) from the surface. These measurements agreed well with one another and did not show any significant time $1 \mathrm{ag}$. Another test measured the hydrogen concentrations 45.72 $\mathrm{cm}$ (18 in.) from the waste surface and near the tank dome. Again the measurements for this tank were virtually identical and there was no time $1 \mathrm{ag}$. These tests proved that the release in tank 241-SY-101 was large enough and quick enough that the entire vapor space volume was uniformly mixed within seconds. However, Reynolds (1994) reports the concentration reached in the vapor space did not exceed the lower flammability limit of hydrogen in air of 4 volume percent, except for 2 of 11 releases.

For the double-she11 flammable gas tanks (241-AN-103, 241-AN-104, 241-AN-105, and 241-AW-101), two analyses have been completed that indicate that the entire vapor space of these other tanks will never reach the lower flammability limit (Reynolds 1994, Wilkins 1994). Additionally, more detailed modeling of tank 241-SY-103 indicated that the release area had to be restricted $\left(37.2 \mathrm{~m}^{2}\left[400 \mathrm{ft}^{2}\right]\right.$ out of $410.4 \mathrm{~m}^{2}\left[4,417.9 \mathrm{ft}^{2}\right]$ [Fox et al. 1993]) and the release had to occur over a few minutes for a local region to develop where the concentration is above the lower flammability limit. This phenomenon is called a plume. Because the volume of the plume containing gas in flammable concentrations is much smaller than the volume of the entire vapor space containing gas in flammable concentrations, the consequences from 
a plume burn are bounded by the consequences from a global burn (Fox and Stepnewski 1994). Frequencies are discussed in Section 3.2 of this appendix.

The argument that the entire vapor space of the single-shell flammable gas tanks is unlikely to reach flammable concentrations also can be made. During the limited time monitoring data on single-shell tanks has been taken, none of the tanks has experienced episodic behavior although the tanks may have the potential to have an episodic release. The tanks of concern (LANL 1994) have been experiencing level growth for 10 to 12 years. If a gas-release event occurs, Alleman et. al. (1994) postulates it would likely take a long time. Additionally, the release would most likely not be a complete tank roll-over (similar to 241-SY-101) simply because the waste types are different (solids, sludges, and salt cakes versus sludges and liquids). Additionally, the standard hydrogen monitoring systems have been in place on the tanks for several months now. Nineteen single-she11 flammable tanks have had hydrogen mounting for at least 6 months. This information will be used in the probability argument later.

Additionally, there are administrative controls for monitoring the flammable gas concentration in the tank during an activity. Before any work begins in a flammable gas tank, the nonflammability of the vapor space will be assured. No work is allowed if the vapor space is above 25 percent of the lower flammability limit. Additionally, if work in the vapor space is in progress, work is to cease if the concentration exceeds 25 percent of the lower flammability limit. A review of existing gas release data and the response of the Whittaker cells showed that if work were being done at the time the release occurred, the $25 \%$ LFL limit would always allow shutdown of activities before the lower flammability 1 imit was released. Given the arguments in the previous paragraphs, a probability of $1 / 100$ (an independent human error) is considered reasonable.

\subsection{DEFINITION OF ACTIVITIES}

Not all tank farm activities have the potential for causing a deflagration. Activities such as dome surveillance; ventilation and balance activities; instrument testing, calibration, repair, or replacement; levelindicating device flushing or repair; and 1 iquid observation well gamma/neutron logging are not considered intrusive activities; that is, they are isolated from the tank atmosphere or are purged. These activities are generally conducted outside of the tank environment and have only a small chance of being a problem. However, because they potentially could result in toxic gas exposures or local deflagrations (the flammable gas concentration is enough to support combustion in the area where work is being performed), prudent work controls still are required. The potential for causing a deflagration inside the tank is considered incredible.

Only activities that have the potential for introducing an ignition source into the tank vapor space and waste are considered when calculating the frequency of a deflagration. Any activity that penetrates the plane of the riser and/or is in direct communication with the tank atmosphere is considered an intrusive activity. This is further broken down into vapor space intrusive activities and waste intrusive activities. Examples of vapor space intrusive activities include, but are not limited to, installing temporary or permanent 
photographic equipment, installing gas monitoring probes, installing equipment in the ventilation system, replacing the level-indicating device (when no isolation valve is present), and sampling the vapor space. Examples of wasteintrusive activities include, but are not 1 imited to, installing instrument trees or liquid observation wells; installing salt well screens; removing or installing jet pumps; and grab, or auger, or push-mode sampling of the waste. Additionally, if several waste-intrusive activities are conducted at the same time, i.e., the tank is open and continuous monitoring with an independent, operable, and functioning system is ongoing, the multiple activities count as one intrusive activity. For example, a riser is open and an auger sample is taken, a hole is lanced in the waste; and then an instrument tree is inserted. All three of these together would be considered one intrusive activity. However, at no time shall the duration of this combination of activities exceed a total of 1 days.

\subsection{FREQUENCY OF FLAMMABLE GAS DEFLAGRATIONS}

The basis for acceptable risk is defined in WHC-CM-4-46 the WHC Safety Analysis Manual. Section 4.1 states the risk frequency is based on the event sequence for each accident scenario, i.e., a per activity risk frequency. The frequency for ignition of flammable gases in the flammable gas tanks is

$$
\text { Ignition Frequency }=\left(P_{\text {FLAMMABLE }}\right)\left(P_{\text {IGNITION }}\right)\left(P_{\text {MONI TORING }}\right)
$$

where

$P_{\text {FLAMAABLE }}$ is the probability that flammable gases concentrations are present.

$P_{\text {IGNITION }}$ is the probability that an ignition source exists even when prevention measures are taken.

$P_{\text {MONJTORING }}$ is the probability that monitoring is not conducted or fails.

The information from the above sections and this equation will be used to determine ignition frequencies for vapor-space intrusive activities and waste intrusive activities.

\subsubsection{Vapor Space Intrusive Activities}

For vapor space intrusive activities, the $P_{\text {flammable }}$ will be $1 / 10$ based on the measured data from the tank vapor spaces in both double-shell and single-shell tanks, $P_{1 G N I T I O M}$ will be $1 / 10,000$ based on the Powers and Morales analysis; and $P_{\text {MONicorivg }}$ will be $1 / 100$ (an independent human failure is estimated to be $1 / 100)^{\circ}$. Substituting these values in the equation gives 


$$
\begin{aligned}
\text { Ignition Frequency } & =\left(1 \times 10^{-1}\right)\left(1 \times 10^{-4}\right)\left(1 \times 10^{-2}\right) \\
& =\left(1 \times 10^{-7}\right) .
\end{aligned}
$$

Thus, the ignition frequency is in the incredible range assuming the independent human failure frequency is estimated to be $1 / 100$.

\subsubsection{Waste Intrusive Activities}

For waste intrusive activities, the $P_{\text {ELAMHagle }}$ will be assumed to be 1 for single-shell flammable gas tanks based on the discussion in Section 1.3 of the main document; $P_{\text {ICNition }}$ will be $1 / 10,00$ based upon the Powers and Morales analysis; and $P_{\text {MONITORING }}$ will be $1 / 100$ (an independent human failures frequency is estimated to be $1 / 100)$. Substituting these values in the equation gives

$$
\begin{aligned}
\text { Ignition Frequency } & =(1)\left(1 \times 10^{-4}\right)\left(1 \times 10^{-2}\right)\left(F_{\text {ACtivities }}\right) \\
& =\left(1 \times 10^{-6}\right)\left(F_{\text {ACtIVItIES }}\right) .
\end{aligned}
$$

Thus, the ignition frequency is in the incredible range assuming the independent human failure is estimated to be 1/100. (See discussion in Section 3.1 of this appendix on the definition of an activity).

\subsection{REFERENCES}

Allemann, R. T., M. E. Brewster, P. A. Gauglitz, J. D. Hopkins, J. D. Hudson, Y. Onishi, C. S. Simmons, and C. W. Stewart, 1995, A Discussion of Some Mechanisms for Sudden Gas Release from Single-Shell Waste Tanks at Hanford, PNL-WTS-101095, Pacific Northwest Laboratory, Richland, Washington.

Coward, H. F., and G. W. Jones, 1952, Limits of Flammability of Gases and Vapors, Bureau of Mines Bulletin 503.

Cowley, W. L., 1994, Evaluation of Hazards to Tank Farm Facilities from Lightning Strikes, WHC-SD-WM-SARR-007, Westinghouse Hanford Company, Richland, Washington.

DOE, 1989, Design and Evaluation Guide7ines for Department of Energy Facilities Subjected to Natural Phenomena Hazards,

Fox, G. L., Jr., D. D. Stepnewski, and R. P. Anantatmula, 1993, Tank 241-SY-103 Hazard Assessment, WHC-SD-WM-SAR-061, Westinghouse Hanford Company, Richland, Washington. 
Fox, G. L., Jr., and D. D. Stepnewski, 1994, Hazard Assessment of Double-Shel7 Flammable Gas Tanks, WHC-SD-WM-SAR-064, Westinghouse Hanford Company, Richland, Washington.

Herborn, D. I., 1991, Hanford Waste Vitrification Plant Preliminary Safety Analysis Report, WHC-EP-0250, Westinghouse Hanford Company, Rich1and, Washington.

Highland, J. A., 1992, WHC Safety Analysis Manual, WHC-CM-4-46, Westinghouse Hanford Company, Richland, Washington.

LANL, 1994, Bounding Gas Release Calculations of Flammable Gas Watch List Singe-She 77 Tanks, LA-UR-94-1323, Los Alamos National Laboratory, Los Alamos, New Mexico.

LANL, Los Alamos National Laboratory, 1995, A Safety Assessment for Proposed Pump Mixing Operations to Mitigate Episodic Gas Releases in Tank 241-SY-101: Hanford Site, Richland, Washington, LA-UR-92-3196, Rev. 14, Los Alamos, New Mexico.

Marusich, R. M., D. C. Deere, and R. J. Van Vleet, 1991, Safety Assessment for Window B Activities in Tank 101-SY, WHC-SD-WM-SAD-003, West inghouse Hanford Company, Richland, Washington.

NFPA, 1993, National Electrical Code, NFPA 70, National Fire Protection Association, Incorporated, Quincy, Massachusetts.

Powers, T. B., and S. D. Morales, 1994, SY Farm Ventilation Isolation Option Risk Assessment Report, WHC-EP-0579, Westinghouse Hanford Company, Richland, Washington.

Reynolds, D. A., 1994, Evaluation of 241-AN Tank Farm Flammable Gas Behavior, WHC-EP-0717, Westinghouse Hanford Company, Richland, Washington.

Savino, A. V., 1995, Tank Farm HLW Compositions and Atmosphere Dispersion Coefficients for Use in ASA Consequence Assessments, WHC-SD-WM-SARR-016, Westinghouse Hanford Company, Richland, Washington.

Scaief, C. C., 1991a, Temperature Measurement Error Analysis, WHC-SD-WM-TI-483 West inghouse Hanford Company, Richland, Washington.

Scaief, C. C., 1991b, Engineering Study of Temperature Sensors for Use in Waste Tank Surveillance, WHC-SD-WM-ES-183, Rev. 0, Westinghouse Hanford Company, Richland, Washington.

Scaief, C. C., 1994, Ignition Analysis, (internal memo to D. D. Stepnewski dated May 24), Westinghouse Hanford Company, Richland, Washington.

Scaief, C. C., 1995, Tank Farm Potential Ignition Sources, WHC-SD-WM-ES-362, Rev. 0, Westinghouse Hanford Company, Richland, Washington. 
Sidpara, A. B, 1995, Operation of the Mitigation-by-Mixing Pump in Tank 241-SX-101, (External letter 95-TSD-107 to President, Westinghouse Hanford Company, August 21), U.S. Department of Energy, Richland, Washington.

Tallman, A. M., 1994, Probabilistic Seismic Hazard Analysis DOE Hanford Site, WHC-SD-W236A-TI-002, Westinghouse Hanford Company, Richland, Washington.

Van Vleet, R. J., 1994, Probability for Ignition in Other Double-Shell Flammable Gas Watch List Tanks, (internal memo 8D114-RJVV-94039 to K. 0. Fein, dated April 21), Westinghouse Hanford Company, Richland, Washington.

Van Vleet, R. J., 1995, Safety Basis for Selected Activities Single-Shell Flammable Gas Tanks, WHC-SD-WM-SARR-004, Rev. 1, West inghouse Hanford Company, Richland, Washington.

Wilkins, N. E., 1994, Evaluation of Tank 241-AW-101 Flammable Gas Behavior, WHC-SD-WM-TI-617, Rev. 0, Westinghouse Hanford Company, Richland, Washington.

WHC-CM-4-46, Safety Analysis Manual, Westinghouse Hanford Company, Richland, Washington. 
WHC-SD-WM-SARR-002 REV 1

This page intentionally left blank.

A-14 
WHC-SD-WM-SARR-002 REV I

\section{APPENDIX B \\ CONSERVATIVE ESTIMATE OF SLURRY GAS COMPOSITION AND LOWER FLAMMABILITY LIMIT IN THE FLAMMABLE GAS TANKS}


WHC-SD-WM-SARR-002 REV 1

This page intentionally left blank. 


\section{APPENDIX B \\ CONSERVATIVE ESTIMATE OF SLURRY GAS COMPOSITION AND LONER FLAMMABILITY LIMIT IN THE FLAMMABLE GAS TANKS}

\subsection{INTRODUCTION}

This document discusses hypothetical slurry gas mixtures. One mixture is a slurry gas totally composed of hydrogen. Such a mixture probably is not physically possible because as vapor space sampling of other tanks has shown, ammonia is present in the vapor spaces of double- and single-shell tanks. Therefore, a reasonable expectation is that some proportion of the gas mixture will be ammonia. A second hypothetical mixture is a slurry gas mixture based on measurements taken in tank 241-SY-101, this mixture was chosen because it has been well characterized. The mixture includes hydrogen, nitrous oxide, methane, carbon monoxide, and ammonia.

However, the lower flammability for this mixture has not been measured. The U.S. Bureau of Mines has done extensive testing with hydrogen/air/oxygen and hydrogen/air mixtures; this yields a lower flammability limit for hydrogen/air/nitrous oxide of 4 volume percent. Limited testing was performed by the U.S. Bureau of Mines for hydrogen/air/nitrous oxide. Again, depending on the interpretation of the data, the lower flammability limit for hydrogen/air/nitrous oxide is around 4 volume percent at room temperature. More extensive testing of gas mixtures may be performed during fiscal year 1995.

\subsection{GAS COMPOSITION}

The composition of the mixture is important. If the mixture is hydrogen and air, it takes a relatively small ignition source $(0.01 \mathrm{~mJ}$ - equivalent to pieces of fabric rubbing together or to stray radio waves) to ignite the mixture. However, only when the hydrogen concentration becomes larger ( $\rightarrow 6$ percent) is combustion rapid and complete. Mixing in other gases (such as ammonia) raises the lower flammability limit. Mixing in other gases also causes the size of the ignition source to increase. Additionally, ignition of mixtures at the lower flammability limit still will be lean burns and often are incomplete. Also, the energetics of the mixture is another issue. of the three gases of concern in tank 241-SY-101, methane is the most energetic on a per mole basis, followed by ammonia, then hydrogen. However, the amount of oxidizer required for combustion varies. Therefore, the most energetic reaction would come from assuming the released gas was methane. However, it is unrealistic to expect 100 percent methane being produced based on the knowledge of gas production mechanisms in tank waste. 


\subsection{DERIVATION OF SLURRY GAS COMPOSITION}

Only one tank, tank 241-SY-101, has had the slurry gas composition measured. The data collection from tank 241-SY-101 was started in April 1990. Instruments used to collect the data included online mass spectrometers, gas chromatographs, electrochemical cells, and Fourier transform infrared spectrometer. Also, confirmatory grab samples have been taken and analyzed to verify collection results.

This data has been used to develop a best estimate and conservative estimate for the gas composition of the slurry gas released in tank 241-SY-101 (Table B-1). The conservative estimate was obtained by maximizing the fuel and toxicological gas content of the mixture within the uncertainty bounds of the measured data (LANL 1995).

Table B-1. Estimates of Gas Composition at $325 \mathrm{~K}^{\mathrm{a}}$

\begin{tabular}{|l|c|c|}
\hline \multicolumn{1}{|c|}{ Gas } & Best estimate (\%) & Conservative estimate (\%) \\
\hline Hydrogen & 28.77 & 31.41 \\
\hline Nitrous oxide & 24.45 & 26.69 \\
\hline Ammonia & 10.95 & 14.95 \\
\hline Nitrogen & 32.82 & 23.51 \\
\hline Methane & 0.35 & 0.53 \\
\hline Others $^{\text {b }}$ & 0.25 & 0.50 \\
\hline Water vapor & 2.40 & 2.40 \\
\hline
\end{tabular}

"This temperature is the maximum temperature in the nonconvecting layer of tank 241-sY-101.

"Carbon monoxide is assumed to be representat ive of "others."

This slurry gas composition is considered conservative for tank 241-SY-101. As more data becomes available for the gas compositions from other flammable gas tanks, the analys is will be changed appropriately. Section 3.0 of this appendix will discuss the energetics of different slurry gas compositions.

\subsection{CONSERVATISMS ASSOCIATED WITH THE SLURRY GAS COMPOSITION}

The ammonia fraction in the release gases is assumed to be a constant. It is considered conservative to use a constant ammonia fraction. The use of a constant ammonia fraction also adds conservatism by maximizing the fuel and toxicological gas content within the uncertainty bounds of the measure data. Additional information on the use of a constant ammonia fraction can be found in Appendix B of the tank 241-SY-101 mixer pump safety assessment (LANL 1995). 
The amount of minor gases is reported, from the measured data, as being 0.5 percent of the noncondensible gases. In this analysis, it will be used as 0.5 percent of the total released gas (both condensible and noncondensible gases). Also, methane will be treated as separate gas. Finally, the gases assumed to be in the minor gas category are assumed to be flammable and are represented as carbon monoxide.

The methane used in this analysis was measured in the gas composition of the tank 241-SY-101 gas release event called Event I, June 1993. The Fourier transform infrared spectrometer is not calibrated extensively for methane and the methane data must be analyzed by hand at 20 percent. Because of the limited number of data points and because the Fourier transform infrared spectrometer methane calibration is not as good as the ammonia calibration, a more conservative uncertainty of 35 percent is applied. Thus, the ratio of methane/nitrous oxide is obtained as 0.02 . For this analys is, this ratio yields a conservative estimate of 0.48 percent methane in the released gas.

\subsection{ENERGETICS}

As mentioned earlier, the fuel in the slurry gas composition has been maximized within the uncertainty of the measured data. This section will develop a model for calculating the equivalent fuel content for different slurry gas compositions. This is done by calculating the equivalent internal energy of the combustion for the mixture and uses the following assumptions:

- The combustion process is approximated as a constant volume process.

- The only combustion products are water, nitrogen, and carbon dioxide (i.e., combustion is complete).

- The available nitrous oxide is consumed first, the remainder of the burn uses oxygen (or air) as an oxidizer.

- The reactants and products behave as an ideal gas mixture.

The Table B-2 provides the combustion reactions of interest and the associated energies of combustion. The internal energy, $u_{R p}$, for an ideal gas mixture is calculated as

$$
u_{R P}=h_{R P}-R T\left(n_{P}-n_{R}\right)
$$

where $h_{R P}$ is the enthalpy of combustion, $R$ is the ideal gas constant, $T$ is the temperature of the vapor space after mixing $(307 \mathrm{~K}), n_{p}$ is the number of moles of products, and $n_{R}$ is the number of moles of reactants. It is assumed that water is in the vapor state. 
Table B-2. Combustion Reactions and Associated Internal Energies.

\begin{tabular}{|c|c|}
\hline Reaction & $\begin{array}{c}\mathrm{u}_{\mathrm{RP}} \\
(\mathrm{kJ} / \mathrm{mole} \text { of fuel) }\end{array}$ \\
\hline $\mathrm{H}_{2}+0.5 \mathrm{O}_{2} \rightarrow \mathrm{H}_{2} \mathrm{O}$ & -240.55 \\
\hline $\mathrm{H}_{2}+\mathrm{N}_{2} \mathrm{O} \rightarrow \mathrm{H}_{2} \mathrm{O}+\mathrm{N}_{2}$ & -323.80 \\
\hline $\mathrm{NH}_{3}+0.75 \mathrm{O}_{2} \rightarrow 1.5 \mathrm{H}_{2} \mathrm{O}+0.5 \mathrm{~N}_{2}$ & -317.44 \\
\hline $\mathrm{NH}_{3}+1.5 \mathrm{~N}_{2} \mathrm{O} \rightarrow 1.5 \mathrm{H}_{2} \mathrm{O}+2 \mathrm{~N}_{2}$ & -442.45 \\
\hline $\mathrm{CH}_{4}+2 \mathrm{O}_{2} \rightarrow 2 \mathrm{H}_{2} \mathrm{O}+\mathrm{CO}_{2}$ & -798.31 \\
\hline $\mathrm{CH}_{4}+4 \mathrm{~N}_{2} \mathrm{O} \rightarrow 2 \mathrm{H}_{2} \mathrm{O}+\mathrm{CO}_{2}+4 \mathrm{~N}_{2}$ & $-1,132.10$ \\
\hline $\mathrm{CO}+0.5 \mathrm{O}_{2} \rightarrow \mathrm{CO}_{2}$ & -281.72 \\
\hline $\mathrm{CO}+\mathrm{N}_{2} \mathrm{O} \rightarrow \mathrm{CO}_{2}+\mathrm{N}_{2}$ & -365.04 \\
\hline
\end{tabular}

Using these energies, the equivalent fuel in terms of volume of hydrogen burning in air can be calculated. First, the fraction of the fuel that is oxidized by nitrous oxide is given by

$$
\theta=\frac{\mathrm{F}\left(\mathrm{N}_{2} \mathrm{O}\right)}{\mathrm{F}\left(\mathrm{H}_{2}\right)+1.5 \mathrm{~F}\left(\mathrm{NH}_{3}\right)+4 \mathrm{~F}\left(\mathrm{CH}_{4}\right)+\mathrm{F}(\mathrm{CO})} .
$$

Then, using the internal energies from Table B-2, the equivalent fuel can be calculated using the following equation.

$$
\begin{aligned}
\text { Fuel }_{\text {EquIV }}= & F\left(H_{2}\right)\left[R_{1} \theta+(1-\theta)\right]+F\left(N_{3}\right)\left[R_{2} \theta+R_{3}(1-\theta)\right]+ \\
& F\left(C_{4}\right)\left[R_{4} \theta+R_{5}(1-\theta)\right]+F(C 0)\left[R_{6} \theta+R_{7}(1-\theta)\right]
\end{aligned}
$$


where

$$
\begin{aligned}
& R_{1}=\frac{-323.80}{-240.55}=1.35 \\
& R_{2}=\frac{-442.45}{-240.55}=1.84 \\
& R_{3}=\frac{-317.44}{-240.55}=1.32 \\
& R_{4}=\frac{-1,132.10}{-240.55}=4.71 \\
& R_{5}=\frac{-798.31}{-240.55}=3.32 \\
& R_{6}=\frac{-365.04}{-240.55}=1.52 \\
& R_{7}=\frac{-281.72}{-240.55}=1.17
\end{aligned}
$$

The use of equivalent fuel allows comparison of varying slurry gas compositions. Figure B-l shows curves for various slurry gas mixtures. One curve shows hydrogen with air; a second curve of hydrogen with nitrous oxide; a third curve with hydrogen, nitrous oxide, and 10 percent ammonia; a fourth curve with hydrogen, nitrous oxide, and 20 percent ammonia; and a fifth curve representing the conservative mixture from Table B-1 (with the exception that the hydrogen is allowed to vary from 0 to 84 percent and nitrous oxide is used account for the remainder of the slurry gas). NOTE: 84 percent is the maximum the hydrogen value can be if the ammonia is at 14.95 percent, the methane is at 0.53 percent, and the carbon monoxide is at 0.5 percent).

For example, if the slurry gas were composed of 30 percent hydrogen (the rest of the slurry gas mixture was inert gases) and there was another oxidizer (no nitrous oxide), the bottom curve would show that 30 percent hydrogen translates into 30 percent hydrogen burning in air.. The conservative estimate curve on Figure B-1 uses nitrous oxide as the remainder of the slurry gas, i.e., after the hydrogen, ammonia, methane and carbon monoxide are accounted for, the remainder is taken as nitrous oxide.

This makes the conservative estimate curve in Figure B-2 slightly more energetic than what was calculated for tank 241-SY-101 (LANL 1995). For example, if the conservative slurry gas concentrations from Table B-1 were used (hydrogen at 31.41 percent, ammonia at 14.95 percent, methane at 0.53 percent, carbon monoxide at 0.5 percent), the remainder ( 52.61 percent) 
WHC-SD-WM-SARR-002 REV 1

Figure B-1. Equivalent Energetics in Terms of Hydrogen in Air for Different Slurry Gas Mixtures.

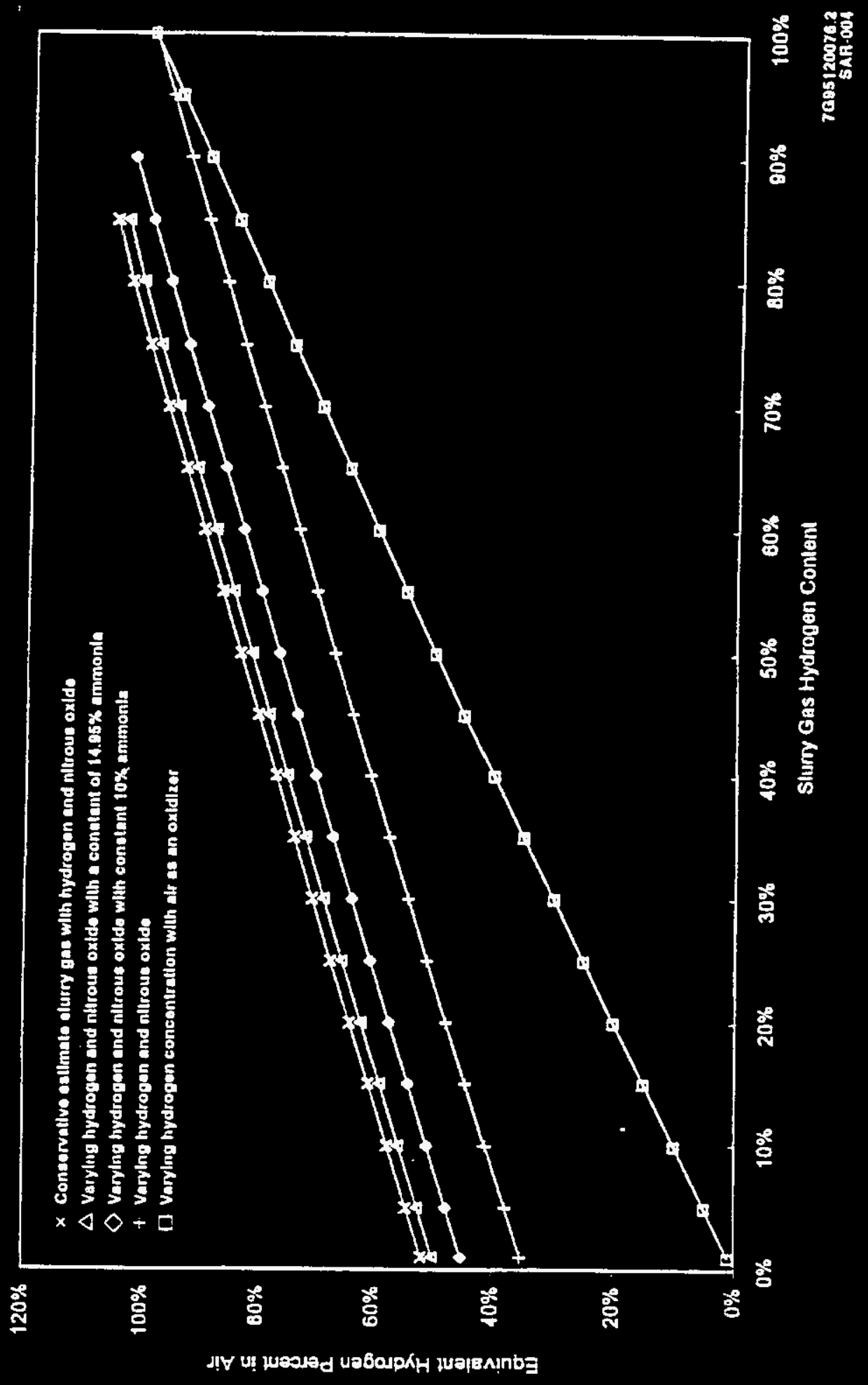


Figure B-2. Lower Flammability Limit as a Function of the Best Estimate (Slurry Gas Composition and Two Oxidizers).

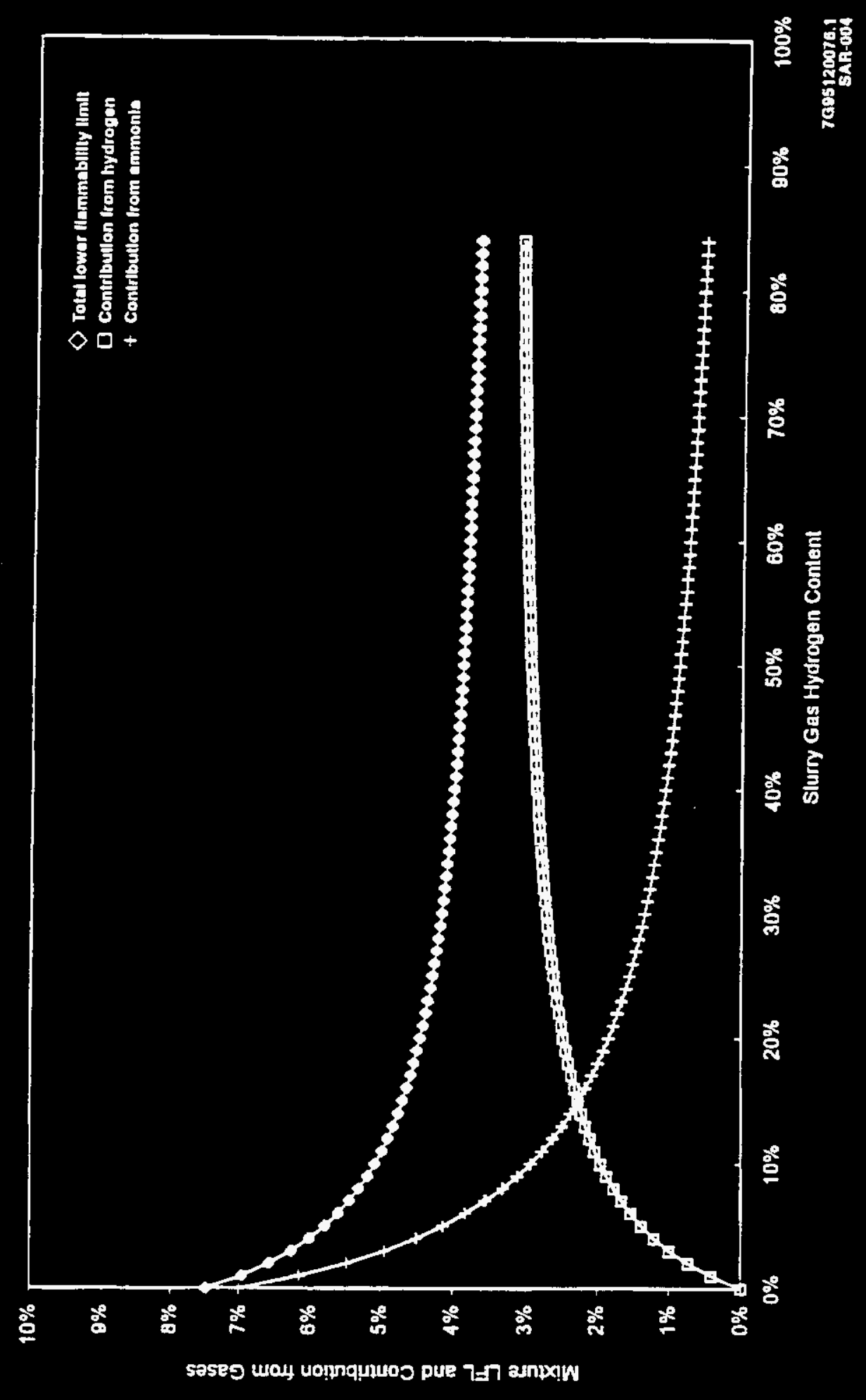


will be nitrous oxide. This mixture would be equivalent to 71.7 percent hydrogen in air (see Figure B-1) (compared with 68.2 percent hydrogen in air [LANL 1995]). Another way of interpreting the chart is that it gives the energy liberated by burning one mole of the mixture (with whatever oxidizer is present). That is, for the first example, the energy liberated is $(0.3)(240.55) \mathrm{kJ} / \mathrm{mole}$ or $72.2 \mathrm{~kJ} / \mathrm{mole}$ and for the second example is $(0.717)(240.55) \mathrm{kJ} / \mathrm{mole}$ or $172.5 \mathrm{~kJ} / \mathrm{mole}$.

Figure B-2 shows that the conservative estimate (i.e., based on tank 241-SY-101) is more energetic than any of the other compositions shown on the graph. Until better data from other flammable gas tanks are available, the conservative estimate will be used for determining consequences.

\subsection{LOWER FLAMMABILITY LIMIT}

\subsection{BACKEROUND}

The lower flammability limit of a mixture depends on a number of parameters. These include the number and types of gases, the number and types of oxidizers, the geometry of the situation, and the energetics of the ignition source. For this estimate, the following assumptions were made.

- LeChatelier's law applies.

- Measured lower flammability limits are the same in the tank environment as they are in the laboratory.

- The mixture of gases does not change the ignition temperature or the energy required to ignite the mixture (as compared to hydrogen).

LeChatelier's law allows a lower flammability limit to be calculated if one knows the fraction of each flammable gas present in the mixture (i.e., the flammable gases are normalized and any other gases are ignored) and the lower flammability limit for each of those constituents. For example, the conservative mixture reported in Table B-1 contains at least seven constituents. However, only four are flammable. These are hydrogen (31.41 percent), ammonia (14.95 percent), methane (0.53 percent) and others (modeled as carbon monoxide 00.5 percent). The fraction of hydrogen is $31.41 /(31.41+14.95+0.53+0.5)$ or 0.663 . Likewise the fractions for ammonia, methane, and carbon monoxide are $0.315,0.011$, and 0.011 , respectively.

Table B-3 gives the lower flammability limit for the flammable gases in air/oxygen (Coward and Jones 1952) and nitrous oxide (Hertzberg and Zlochower 1993). 
Table B-3. Lower Flammability Limits in Various Oxidizers.

\begin{tabular}{|c|c|c|}
\hline \multirow{2}{*}{ Gas } & \multicolumn{2}{|c|}{ Lower flammability limit } \\
\cline { 2 - 3 } & Air/oxygen & Nitrous oxide \\
\hline Hydrogen & $3.5^{\mathrm{a}}$ & 1.8 \\
\hline Ammonia & $8.0^{\mathrm{b}}$ & 2.0 \\
\hline Methane & 5.0 & 0.8 \\
\hline Carbon monoxide & 12.5 & -- \\
\hline
\end{tabular}

"This is the lower flammability limit for hydrogen at $400 \mathrm{~K}$ and the others were measured at $293 \mathrm{~K}$.

'This value was used to represent the upward propagation limit. Further research did not find support for this number. The value commonly used is 15 percent.

LeChatelier's law (Coward and Jones) is

$$
L F L_{\text {mixture }}=\frac{1}{\frac{f_{1}}{L F L_{1}}+\frac{f_{2}}{L F L_{2}}+\cdots+\frac{f_{n}}{L F L_{n}}}
$$

where LFL is the lower flammability limit of the particular gas and $f$ is the normalized fraction of the particular flammable gas. Thus, for the slurry gas conservative estimate (see Table B-1), the lower flammability limit in air is 4.68 percent while in nitrous oxide it is 1.86 percent. However, this is for one particular mixture of slurry gases.

\subsection{OPERATING LIMITS FOR IN-TANK ACTIVITIES}

Because the standard hydrogen monitoring system measures for only one gas, e.g., hydrogen, appropriate limits must be set for in-tank activities. To set limits, some assumptions must be made on potential slurry gas compositions and on oxidizers. The following assumptions will be used:

- The slurry gas will contain four flammable gases. Ammonia will be a constant at 14.95 percent, methane a constant at 0.53 percent, and carbon monoxide a constant at 0.5 percent. Hydrogen will be allowed to vary from 0 to 84 percent.

- The maximum amount of nitrous oxide available for combustion is bounded by tank 241-SY-101. It is assumed that the volume available for the released gas to $\operatorname{mix}$ is only the hemispherical portion (no credit is taken for the cylindrical volume above the waste). This volume is $950 \mathrm{~m}^{3}$. The maximum expected gas release event from tank 241-SY-101 is $263 \mathrm{~m}^{3}$ of slurry gas. Of this, 26.69 percent is nitrous oxide. Thus, the amount of oxidizer that will be nitrous oxide is given by $(0.2669)(263 / 950)$ or 7.4 percent. 
The limited literature available on burns in air/oxygen with nitrous oxide indicates that the lower flammability limit is linear function depending only on the amount of nitrous oxide versus air/oxygen (i.e., a simple weighted average). Figure B-2 presents the lower flammability limit of slurry gas compositions with 92.6 percent air and 7.4 percent nitrous oxide.

Current operating experience with tank 241-SY-101 and tank 241-AW-101 indicates that the percent hydrogen in the slurry gas mixture can range from approximately 30 percent to 70 percent. Over this range, the lower flammability limit ranges from approximately 4.5 to 3.9 percent. of this, the hydrogen contribution to the lower flammability limit would yield concentrations in the tank ranging from approximately 2.5 to 3.0 percent (see Figure B-2). Hydrogen is the only flammable gas measured. To conduct activities safely in a tank, a limit must be chosen that will cause activities to cease before there is any problem with flammability. The National Fire Protection Association, Inc., indicates that 25 percent of the lower flammability limit is the cut off for stopping activities. For the currently known situation, the safety limit should be $(0.25)$ times (2.5 percent) or 0.625 percent $(6,250 \mathrm{ppm})$ for hydrogen. If additional monitoring is added for ammonia, a limit for ammonia would be (0.25) times (0.86 percent) or 0.215 percent $(2,150 \mathrm{ppm})$. NOTE: If the value used for the lower flammability 1 imit of ammonia is changed from 8 percent to 15 percent as noted in Table B-3, the monitoring levels would change to 7,375 ppm for hydrogen and $1,700 \mathrm{ppm}$ for ammonia.

\subsection{CONCLUSIONS}

To operate safely, an analys is was performed to determine a conservative estimate of slurry gas composition. This slurry gas composition was shown to be more energetic than a few other mixtures. The lower flammability limit was developed over a range of hydrogen concentrations using the conservative slurry gas composition. An operating 1 imit of 6,250 ppm hydrogen is set for in-tank activities. Additionally, for future contingencies, an operating limit of 2,150 ppm of ammonia was developed. As more data are obtained from the tanks, the information on slurry gas compositions, lower flammability limits, and operating limits may change.

\subsection{REFERENCES}

Coward, H. F., and G. W. Jones, 1952, Limits of Flammability of Gases and Vapors, Bulletin 503, Bureau of Mines, Pittsburgh, Pennsylvania.

Hertzberg, M., and I. A. Zlochower, 1993, Explosibility of Nitrous Oxide Gas: The Effect of H-Atom-Bearing Impurities, $25^{\text {th }}$ International Symposium on Combustion, University of California, Irvine, California. 
LANL, Los Alamos National Laboratory, 1995, A Safety Assessment for Proposed Pump Mixing Operations to Mitigate Episodic Gas Releases in Tank 241-SY-101: Hanford Site, Richland, Washington, LA-UR-92-3196, Rev. 14, Los Alamos, New Mexico. 
WHC-SD-WM-SARR-002 REV 1

This page intentionally left blank. 
WHC-SD-WM-SARR-002 REV 1

APPENDIX C

DEVELOPMENT OF THE RISER PURGE TIME REQUIREMENTS

$c-i$ 
WHC-SD-WM-SARR-002 REV 1

This page intentionally left blank.

$c-i j$ 


\section{APPENDIX C}

\section{DEVELOPMENT OF THE RISER PURGE TIME REQUIREMENTS}

When an initially capped riser on a passively ventilated waste tank is opened, gases within it will be purged by density-driven flows and in actively ventilated tanks by the pressure gradient between the tank and ambient. Epstein (Epstein et al. 1994) systematically surveyed the possible mechanisms for gas exchange between single-shell tanks and the ambient. A letter (Plys 1994) suggested an equation that can be used to predict the purge rate and therefore the characteristic time for purging the riser. Because no tank is perfectly isolated (i.e., there are always leak paths), a limiting flow rate is given when the flow resistance is dominated by a filter. The volumetric purge rate is given by:

$$
Q=\frac{c \Delta \rho g \mathrm{~L}}{\mathrm{R}}
$$

where

$$
\begin{aligned}
c & =\text { Geometric coefficient } \\
& =0.5 \text { (for a single filter) } \\
& =1.0 \text { (for two filters) } \\
\Delta 0 & =\text { Density difference, } \mathrm{kg} / \mathrm{m}^{3} \\
g & =\text { Acceleration of gravity } \\
& =9.81 \mathrm{~m} / \mathrm{s}^{2} \\
L & =R i s e r \text { length, } \mathrm{m} . \\
R & =F i 1 \text { ter resistance } \\
& =2,340 \mathrm{~Pa} .
\end{aligned}
$$

NOTE: The density difference in the equation may be related to molecular weight differences or temperature differences. The latter is chosen because the temperature differences are a factor of 3 to 10 more important (Plys 1994). Thus,

$$
\Delta o=\frac{\rho \Delta T}{T} .
$$

Assuming, $\rho_{3}=1.1 \mathrm{~kg} / \mathrm{m}^{3}, \Delta \mathrm{T}=6 \mathrm{~K}, \mathrm{~T}=300 \mathrm{~K}$, and $\mathrm{L}=3 \mathrm{~m}$, yie $7 \mathrm{ds}$ $Q=2.8 \times 10^{-4} \mathrm{~m}^{3} / \mathrm{s}$. Because the volume of a riser with a diameter of $10.2 \mathrm{~cm}$ ( 4 in.) and a length of $3 \mathrm{~m}$ is about $0.024 \mathrm{~m}^{3}$, the time to flush the riser would be given by 


$$
\begin{aligned}
V / Q & =\frac{0.024 \mathrm{~m}^{3}}{0.00024 \mathrm{~m}^{3} / \mathrm{s}} \\
& =86 \mathrm{~s} \\
& =1.5 \mathrm{~min} .
\end{aligned}
$$

NOTE: If the concentration of hydrogen in the riser was 1 percent, the flow rate would be 50 percent higher and the purge time would be about 1 minute.

The above volumetric purge rate equation can be used to provide the basis for the purge times associated with opening a riser on a single-shell tank

\begin{tabular}{|c|c|c|}
\hline$\Delta \mathrm{T}$ Range & $\begin{array}{l}\text { Purge time } \\
\text { (min) }\end{array}$ & $\begin{array}{l}\text { Required time } \\
\text { (min) }\end{array}$ \\
\hline $\begin{array}{c}\Delta \mathrm{T} \geq{ }^{26 \mathrm{~K}} \\
\left(\Delta \mathrm{T} \geq \underset{\text { or }}{ }{ }^{\circ} \mathrm{F}\right) \\
\text { tank is on active ventilation }\end{array}$ & 1.5 & 5.0 \\
\hline $\begin{array}{c}3 \leq \Delta \mathrm{T}<6 \mathrm{~K} \\
\left(5.4^{\circ} \leq \Delta \mathrm{T}<10.8{ }^{\circ} \mathrm{F}\right)\end{array}$ & 3.0 & 10.0 \\
\hline $\begin{array}{c}1 \leq \Delta T<3 \mathrm{~K} \\
\left(1.8^{1} \leq \Delta T<5.4^{\circ} \mathrm{F}\right)\end{array}$ & 9.0 & 30.0 \\
\hline $\begin{aligned} \Delta \mathrm{T} & <1 \mathrm{~K}^{\circ} \\
(\Delta \mathrm{T} & \left.<1.8^{\circ} \mathrm{F}\right)\end{aligned}$ & \multicolumn{2}{|c|}{$\begin{array}{l}\text { Wait until } \Delta T \text { will fall into one of the } \\
\text { defined categories above }\end{array}$} \\
\hline
\end{tabular}
flammable gas tank.

Table C-1. Required Riser Purge Times.

"Time required to purge one volume.

'T ime required to purge three volumes.

\section{REFERENCES}

Epstein, M., et a1., 1994, Ferrocyanide Safety Program: An Assessment of the Possibility of Ferrocyanide Sludge Dryout, WHC-EP-0816, Westinghouse Hanford Company, Richland, Washington.

Plys, M. G., 1994, Riser Purge Transient, (external letter to R. J. Van Vleet, November 28), Fauske \& Associates, Inc., Burr Ridge, Illinois. 
WHC-SD-WM-SARR-002 REV 1

APPENDIX D

DEFINITION OF NATIONAL FIRE PROTECTION ASSOCIATION TERMS

$D-i$ 
WHC-SD-WM-SARR-002 REV 1

This page intentionally left blank. 


\section{APPENDIX D \\ DEFINITION OF NATIONAL FIRE PROTECTION ASSOCIATION TERMS}

This appendix contains the definitions for the various terms used by the National Fire Protection Association. The following two definitions are direct quotes from NFPA 496, Standard for Purged and Pressurized Enclosures for Electrical Equipment.

Class I, Division 1. A Class I, Division 1 location is a location: (1) in which ignitable concentrations of flammable gases or vapors can exist under normal operating conditions; or (2) in which ignitable concentrations of such gases or vapors may exist frequently because of repair or maintenance operations or because of leakage; or (3) in which breakdown or faulty operation of equipment or processes might release ignitable concentrations of flammable gases or vapors and might also cause simultaneous failure of electric equipment. (See Article 500-5[a] of NFPA 70, National Electrical Code.)

Class I, Division 2. A Class I, Division 2 location is a location: (1) in which volatile flammable liquids or flammable gases are handled, processed, or used, but in which the 1iquids, vapors, or gases will normally be confined within closed containers or closed systems from which they can escape only in case of accidental rupture or breakdown of such containers or systems, or in case of abnormal operation of equipment; or (2) in which ignitable concentrations of gases or vapors that are normally prevented by positive mechanical ventilation and that might become hazardous through failure or abnormal operation of the ventilating equipment; or (3) that is adjacent to a Class I, Division I location and to which ignitable concentrations of gases or vapors might occasionally be communicated unless such communication is prevented by adequate positive-pressure ventilation from a source of clean air, and effective safeguards against ventilation failure are provided. (See Article 500-5[b] of NFPA 70, National Electrical Code.)

The following definitions of $\mathrm{Cl}$ ass I Groups are direct quotes from Article 500-3 of NFPA 70, National Electrical Code.

Group A. Atmospheres containing acetylene.

Group B. Atmospheres containing hydrogen, fuel and combustible process gases containing more than 30 percent hydrogen by volume, or gases or vapors of equivalent hazard such as butadiene, ethylene oxide, propylene osice, and acrolein.

Group C. Atmospheres such as ethyl ether, ethylene, or gases or vapors of equivalent hazard. 
Group D. Atmospheres such as acetone, ammonia, benzene, butane, cyclopropane, ethanol, gasoline, hexane, methanol, methane, natural gas, naptha, propane, or gases or vapors of equivalent hazard.

\section{REFERENCES}

NFPA, 1993, National Electrical Code, NFPA 70, Article 500-3, National Fire Protection Association, Quincy, Massachusetts.

NFPA, 1993, Purged and Pressurized Enclosures for Electrical Equipment, NFPA 496, National Fire Protection Association, Quincy, Massachusetts. 
WHC-SD-WM-SARR-002 REV 1

\section{APPENDIX E \\ PEER REVIEW CHECKLISTS}

$E-i$ 
WHC-SD-WM-SARR-002 REV 1

This page intentionally left blank. 
PEER REYIEN CHECKLIST

Document Reviewed: Appendix A, titled "FREQUENCY OF OCCURRENCE OF IGNITION", for WHC-SD-WM-SARR-004 REV. 1 DRAFT (This review will

Author: Dr. Rick J. Van Vleet

Date: Peer review performed on January 18, 1996

Scope of Review: Text of Appendix A including checking calculations

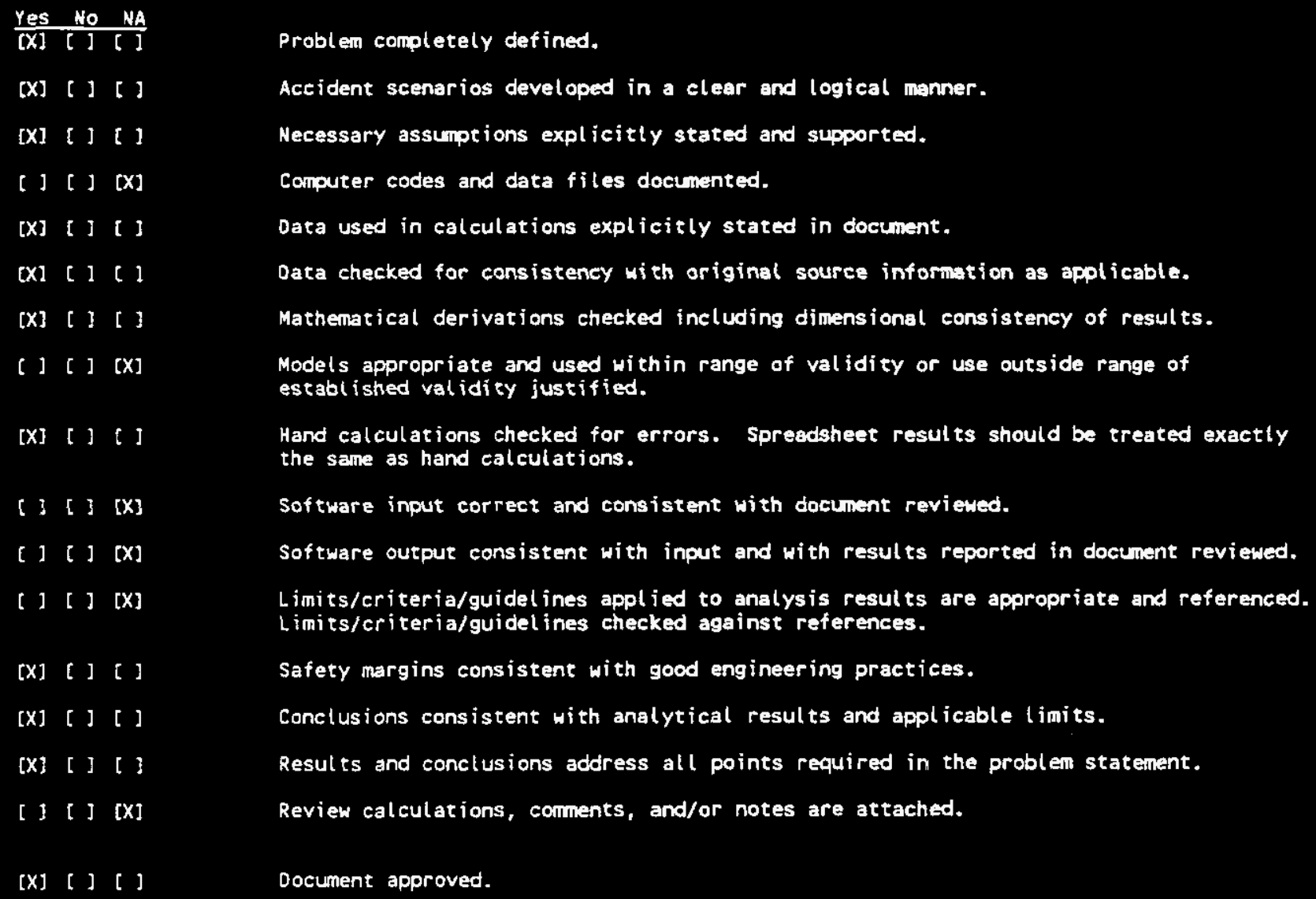

\section{COMMENTS :}

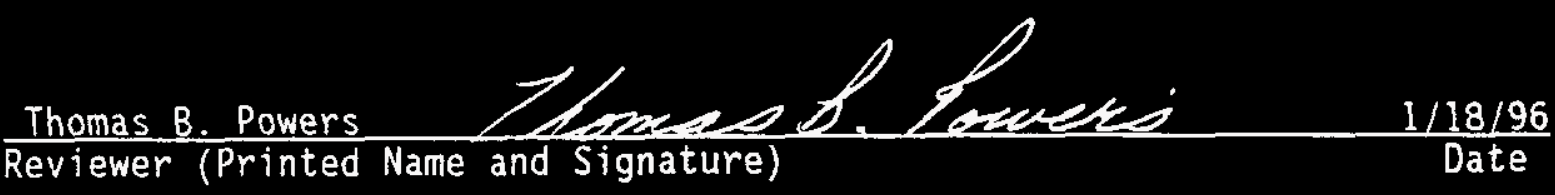




\section{PEER REVIEW CHECKLIST}

Document Reviewed: SARR-004, Safety Basis for Selected Activities in SingleShell Flammable Gas Tanks, and

SARR-002, Safety Bas is for Selected Activities in DoubleShel1 Flammable Gas Tanks

Author: R. J. Van Vleet, Ph.D.

Date: January 16, 1995

Scope of Review: This review and the informal comments provided considered readabiltiy and consistenancy only.

$\frac{\text { Yes No NA }}{[][][x]}$

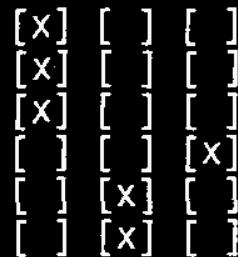

$[\mathrm{C}][\mathrm{x}][\mathrm{c}$

[ ] [ ] [x]

$[\mathrm{l}][\mathrm{x}][\mathrm{s}$

$\left[\begin{array}{lll}] & {[} & {[x]} \\ ] & {[}\end{array}\right][x]$

[][]$[x]$

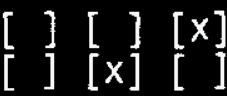

$[\mathrm{l}][\mathrm{x}][\mathrm{c}$

$[\mathrm{x}][\mathrm{x}]$

[ ] [ [ $]$

\section{[ ] [ ] $[x]$}

Previous reviews complete and cover analysis, up to scope of this review, with no gaps.

Problem completely defined.

Accident scenarios developed in a clear and logical manner. Necessary assumptions explicitly stated and supported. Computer codes and data files documented.

Data used in calculations explicitly stated in document.

Data checked for consistency with original source information as applicable.

Mathematical derivations checked including dimensional consistency of results.

Models appropriate and used within range of validity or use outside range of established validity justified.

Hand calculations checked for errors. Spreadsheet results should be treated exactly the same as hand calculations. Software input correct and consistent with document reviewed. Software output consistent with input and with results reported in document reviewed.

Limits/criteria/guidelines applied to analysis results are appropriate and referenced. Limits/criteria/guidelines checked against references.

Safety margins consistent with good engineering practices. Conclusions consistent with analytical results and applicable limits.

Results and conclusions address all points required in the problem statement.

Format consistent with appropriate NRC Regulatory Guide or other standards

Review calculations, comments, and/or notes are attached.

Document approved.

G. R. Sawtelle

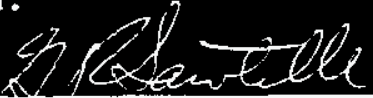

Reviewer (Printed Name and Signature)

January 19,1996 Date

The checklist further identifies what the scope of the review does or does not cover. "No" and "NA" marks only indicate the applicability to this review. 


\section{PEER REVIEN CHECKLIST}

Document Reviewed: WHC-SD-SARR-002 REV I

Author: R. J. Van Vleet

Date: January 18, 1996

Scope of Review: Radiological and toxic release calculations in Chapter 5

$\frac{\text { Yes } \mathrm{No} N \mathrm{NA}}{[\mathrm{X}][\mathrm{I}]}$

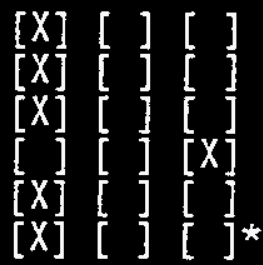

[ ] [ ] [X]

[X] [ ] [ ]

[X] [ ] [ ]

[]$\left[\begin{array}{ll}] & {[X]} \\ {[} & {[}\end{array}\right]$

[X] [ ] [ ]

$[x]\left[\begin{array}{lll}{[} & {[X]}\end{array}\right]$

[X] [ ] [ ]

[ ] [ ] [X]

[ ] [ ] $[X]$

[X] [ ] [ ] Calculation approved. this review, with no gaps. as applicable. consistency of results. limits. problem statement. other standards

Previous reviews complete and cover analysis, up to scope of

Problem completely defined.

Accident scenarios developed in a clear and logical manner. Necessary assumptions explicitiy stated and supported. Computer codes and data files documented.

Data used in calculations explicitly stated in document.

Data checked for consistency with original source information

Mathematical derivations checked including dimensional

Models appropriate and used within range of validity or use outside range of established validity justified.

Hand calculations checked for errors. Spreadsheet results should be treated exactly the same as hand calculations. Software input correct and consistent with document reviewed. Software output consistent with input and with results reported in document reviewed. Limits/criteria/guidelines applied to analys is results are appropriate and referenced. Limits/criteria/guidelines checked against references.

Safety margins consistent with good engineering practices. Conclusions consistent with analytical results and applicable

Results and conclusions address all points required in the

Format consistent with appropriate NRC Regulatory Guide or

Review calculations, comments, and/or notes are attached.

J. C. Van Keuren

$1 / 18 / 96$ Reviewer (Printed Name and Signature)

Calculation is consistent with ASA approach and values. 
WHC-SD-WM-SARR-002 REV 1

This page intentionally lest blank. 
WHC-SD-WM-SARR-002 REV 1

This page intentionally left blank.

$E-5$ 
WHC-SD-WM-SARR-002 REV 1

This page intentionally left blank.

$E-6$ 


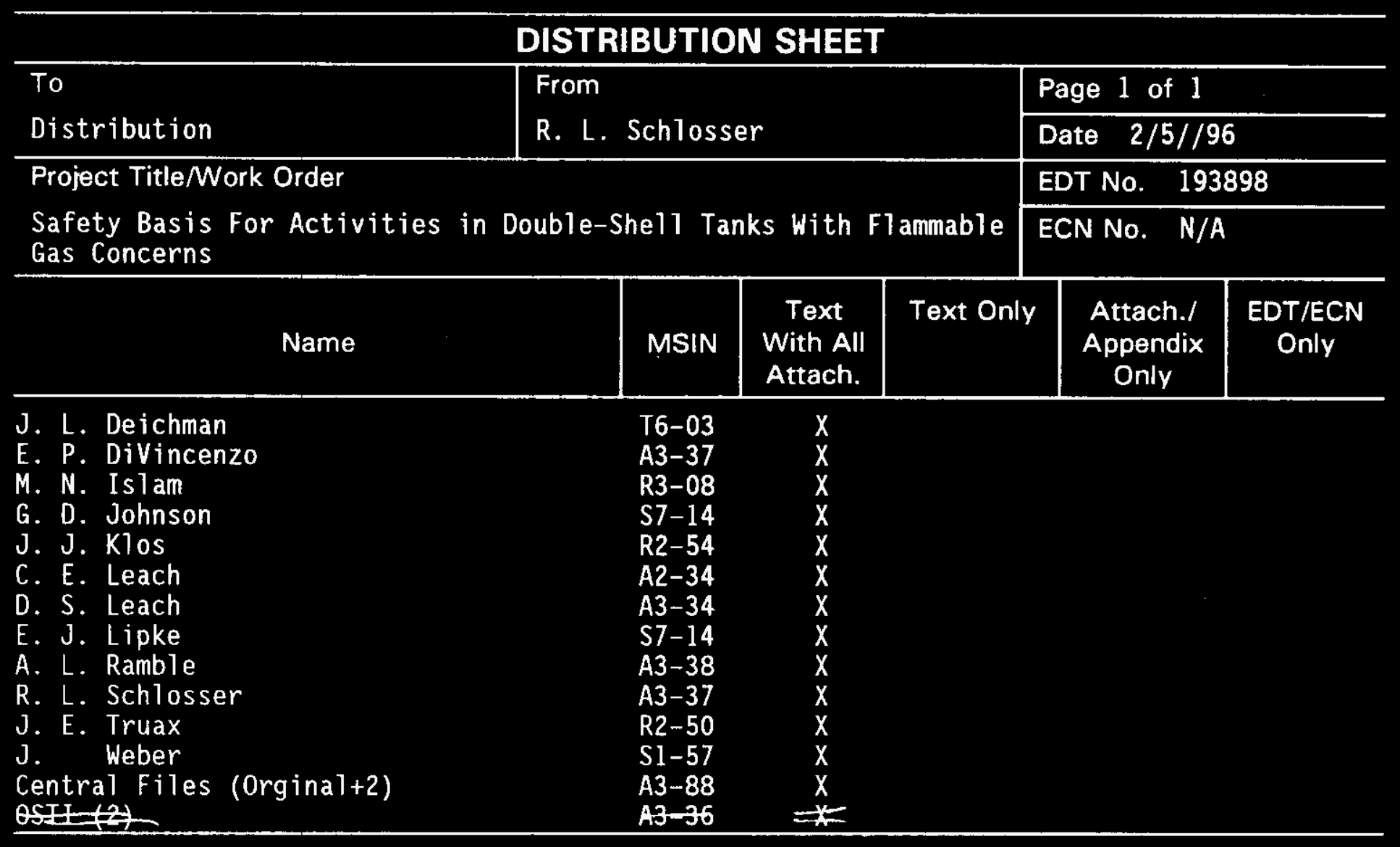

